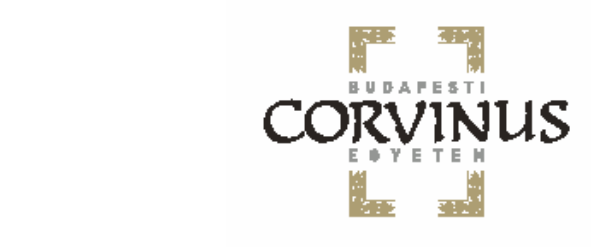

BUDAPESTI CORVINUS EGYETEM

DOKTORI ÉRTEKEZÉS

DEÁK ZSUZSANNA

\title{
A KÖRNYEZETTUDATOS VÁLLALATI MAGATARTÁS ÉS A TŐKEPIACI ÉRTÉK
}




\section{A doktori iskola megnevezése:}

Tájépítészeti és Tájökológiai Doktori Iskola

(Tájépítészet és Döntéstámogató Rendszerek Doktori Iskola)

tudományága: agrármúszaki tudomány

vezetője: $\quad$ Dr. habil. Csemez Attila, Dsc

tanszékvezető egyetemi tanár

Témavezető: $\quad$ Dr. habil. Hajdu Istvánné, Csc

egyetemi tanár

Budapesti Corvinus Egyetem

Élelmiszertudományi Kar

Élemiszeripari Gazdaságtan Tanszék

A jelölt a Budapesti Corvinus Egyetem Doktori Szabályzatában elöírt valamennyi feltételnek eleget tett, az értekezés mühelyvitájában elhangzott észrevételeket és javaslatokat az értekezés átdolgozásakor figyelembe vette, ezért az értekezés nyilvános vitára bocsátható.

Az iskolavezető jóváhagyása

A témavezető jóváhagyása 
A Budapesti Corvinus Egyetem Élettudományi Területi Doktori Tanács 2012. december 4.i határozatában a nyilvános vita lefolytatására az alábbi bíráló Bizottságot jelölte ki:

\section{BÍRÁLÓ BIZOTTSÁG:}

Elnöke:

Dr. Forgács Csaba

\section{Tagjai:}

Dr. Zilahy Gyula

Dr. Csete Mária

Dr. Szabóné Dr. Erdélyi Éva

Dr. Farkasné Dr. Fekete Mária

Opponensek:

Dr. Podruzsik Szilárd

Dr. Kapronczai István

Titkár:

Dr. Kajári Karolina 


\section{TARTALOMJEGYZÉK}

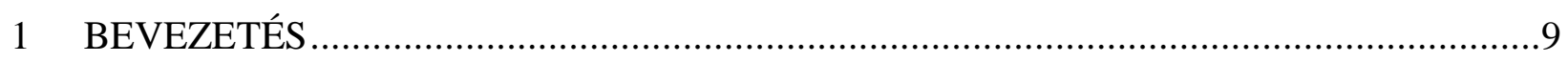

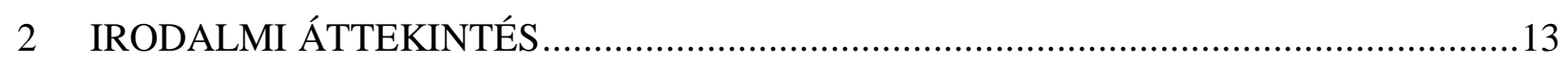

2.1 A felelős vállalatirányítás és a fenntartható fejlődés ...............................................13

2.2 Egymásnak ellentmondó teóriák, vagy egymást kiegészítő elképzelések?....................15

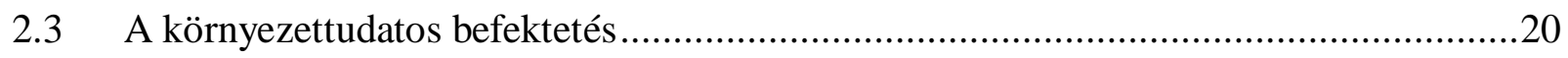

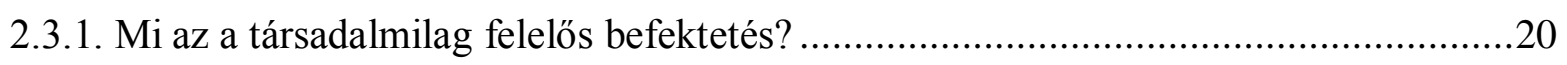

2.3.2. Tendenciák a társadalmilag felelős befektetés piacán ................................................22

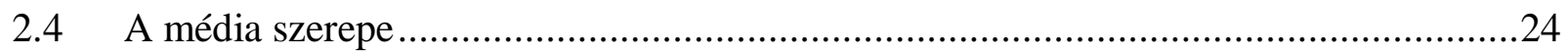

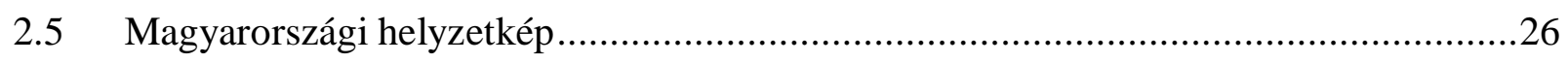

2.6 Globális tendenciák a nemzetközi élelmiszeriparban ..................................................30

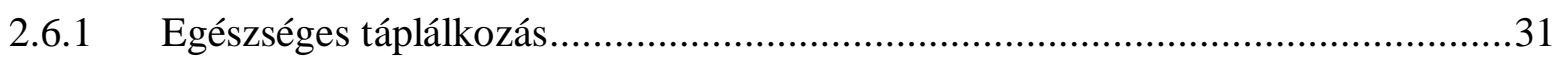

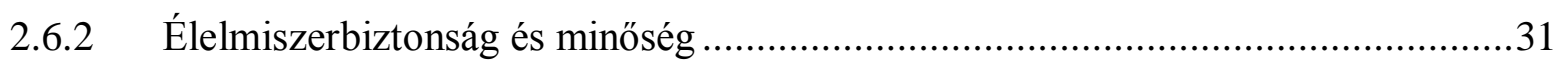

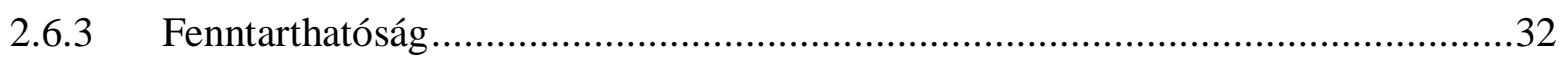

2.7 A nemzetközi élelmiszeripar környezeti teljesítménye ...................................................33

2.8 A környezeti és pénzügyi teljesítmény mérése ................................................................

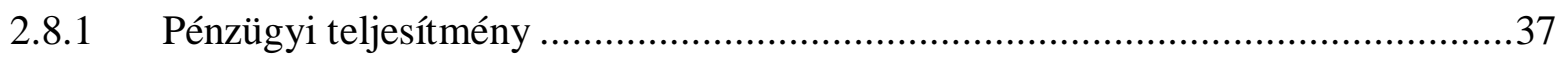

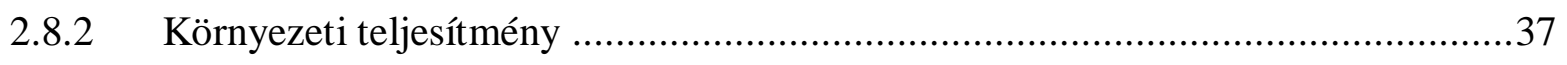

2.9 A környezeti és pénzügyi teljesítmény közötti összefüggés ............................................38

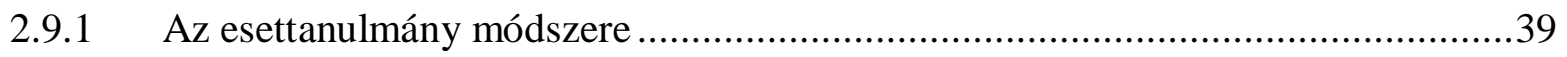

2.9.2 Az értékbecslési model ..................................................................................

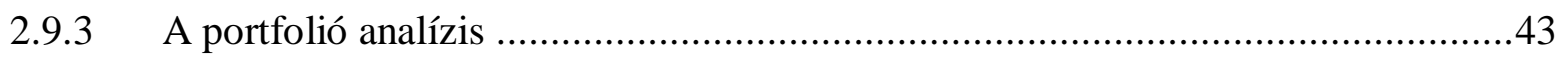

2.9.4 A portfolió elemzés kiterjesztése .......................................................................44

2.10 Az eseménytanulmány ökonometriai módszerei ...........................................................46

2.11 A témakör kutatási eredményeinek áttekintése .........................................................49

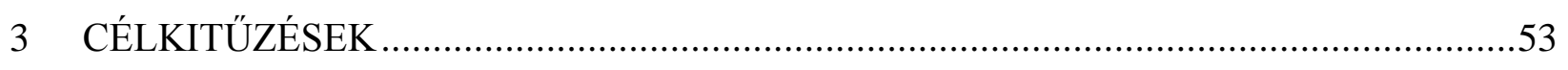

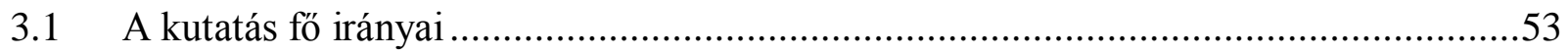




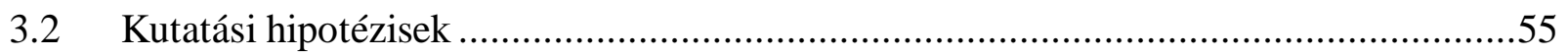

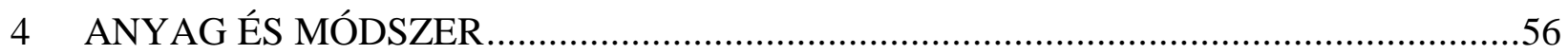

4.1 A nemzetközi élelmiszervállalatok és statisztikai jellemzőik .......................................56

4.2 A változók és alcsoportok bemutatása ....................................................................59

4.3 Alkalmazott ökonometriai módszerek ………………………..............................63

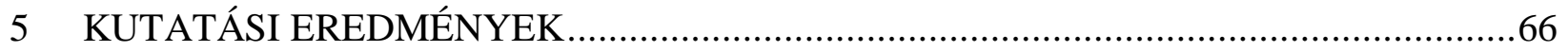

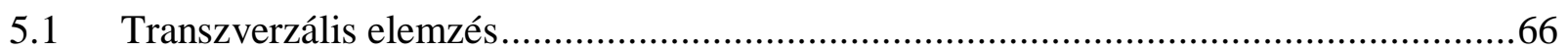

5.1.1 Környezeti események típusa szerint ................................................................66

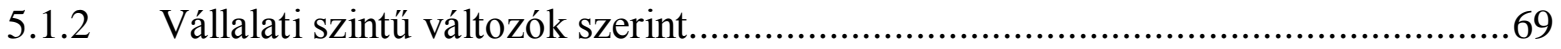

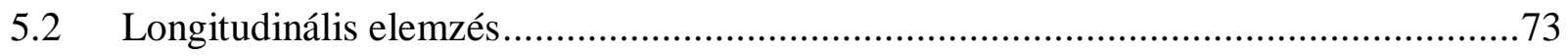

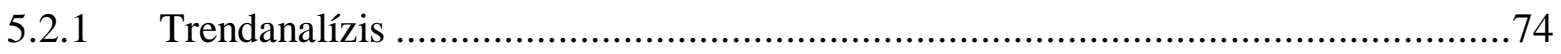

5.2.2 A populációk sztochasztikus ugyanakkoriságának vizsgálata ................................77

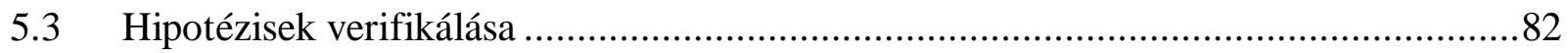

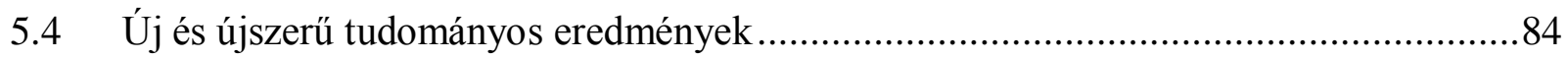

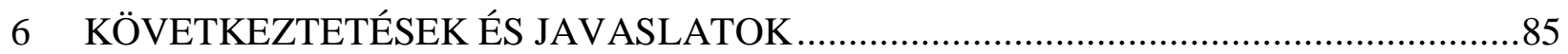

6.1 A környezeti események típus szerinti elemzéséből származó következtetések és

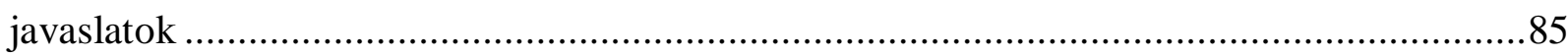

6.2 A vállalati jellemzők szerinti elemzéséből származó következtetések és javaslatok .....85

6.3 A longitudinális elemzéséből származó következtetések és javaslatok ..........................86

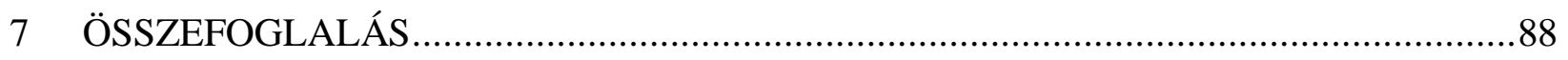

8 SUMMARY

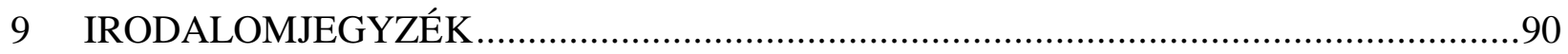

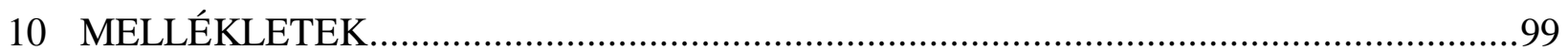

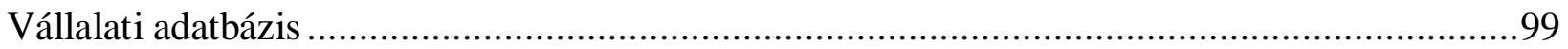

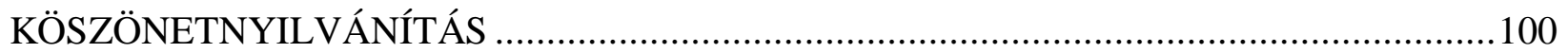

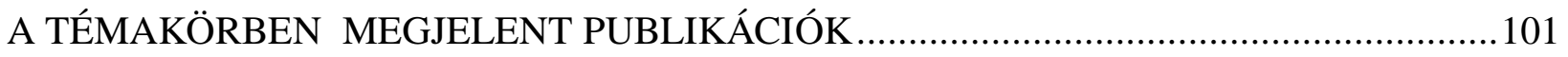




\section{ÁBRAJEGYZÉK}

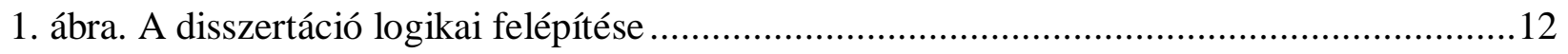

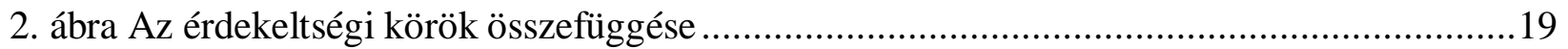

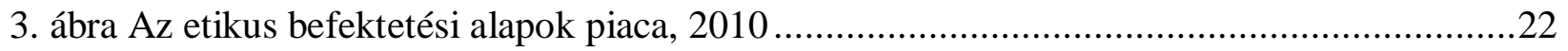

4. ábra Az etikus befektetési alapok teljesítménye vs. S\&P500 …………………....................23

5. ábra Környezetvédelmi témájú cikkek a New York Times ban, 1980-2009...........................24

6. ábra A környezeti kommunikáció fejlettségének indexe Magyarországon...............................26

7. ábra Környezetirányítási rendszerek használata a magyarországi élelmiszeriparban................27

8. ábra A Humánfejlettségi Mutató (Human Development Index, HDI) alakulása Magyarországon (HUN) és az Egyesült Államokban (US) ....................................................29

9. ábra Egy eurónyi háztartási kiadásra eső kategóriánkénti környezeti hatások az Európai

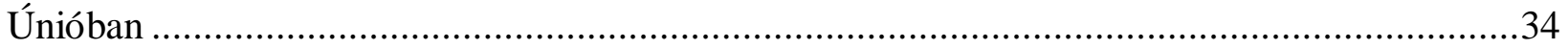

10. ábra Piaci reakció előre nem látott negatív eseményre ……..................................................41

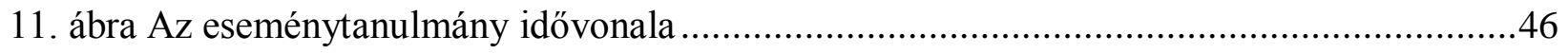

12. ábra A vizsgált vállalatok élelmiszertermelési ágazat szerint .............................................56

13. ábra Eseménytípusok gyakoriságának alakulása a nyomtatott médiában 1990-2010 között..74 14. ábra E1 típusú események három napos abnormális hozamainak és átlagos abszolút eltérésének lineáris trendgörbéje

15. ábra E2 típusú események három napos abnormális hozamainak és átlagos abszolút eltérésének lineáris trendgörbéje .75

16. ábra E3 típusú események három napos abnormális hozamainak és átlagos abszolút eltérésének lineáris trendgörbéje .76

17. ábra E4 típusú események három napos abnormális hozamainak és átlagos abszolút eltérésének lineáris trendgörbéje .76

18.ábra E1 portfolió: negatív belső események kumulált átlagos három napos abnormális hozamának alakulása. .78

19. ábra E2 portfolió: pozitív belső események kumulált átlagos három napos abnormális hozamának alakulása.....

20. ábra E3 portfolió: pozitív külső események kumulált átlagos három napos abnormális hozamának alakulása.

21. ábra E4 portfolió: negatív külső események kumulált átlagos háromnapos abnormális hozamának alakulása. .80 


\section{TÁBLÁZATJEGYZÉK}

1. táblázat Globális tendenciák a nemzetközi élelmiszeriparban .........................................30

2. táblázat Az étkezésnek és italfogyasztásnak tulajdonítható szennyezőanyag kibocsátások .....34

3. táblázat Környezeti teljesítmény iparágak szerinti besorolása ..........................................36

4. táblázat A Factiva adatbázisban felhasznált kulcsszavak jegyzéke ..................................57

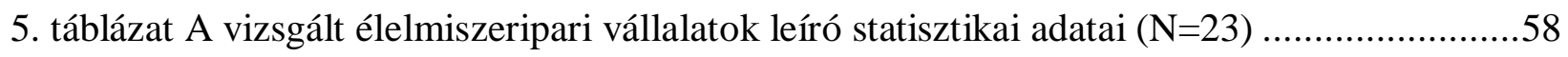

6. táblázat Vállalati szintű mutatók kategóriák és csoportok szerinti lebontása .......................61

7. táblázat A környezeti események megoszlása esemény típus és év szerint (longitudinális

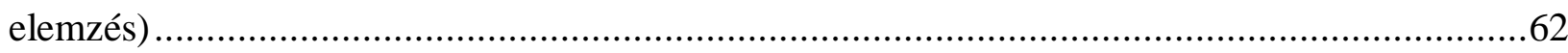

8. táblázat A környezeti események megoszlása eseménytípus szerint ................................66

9. táblázat Eseménytípus szerinti átlagos abnormális hozamok és szignifikancia szintjük .........67

10. táblázat Vállalatonkénti kumulált abnormális hozamok és szignifikancia szintjük...............67

11. táblázat A környezeti események megoszlása esemény típus és év szerint (transzverzális

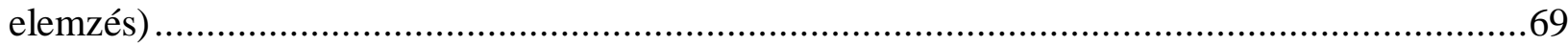

12. táblázat A vállalati szintü változók hatása az abnormális hozamokra ...............................70

13. táblázat Az E1-E4 események kiválasztott időintervallumainak átlagos és medián három

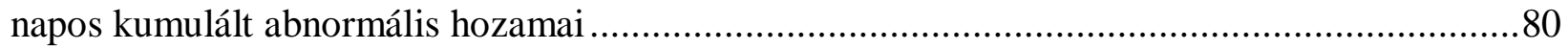

14. táblázat A Mann-Whitney post-hoc teszt eredményei (Bonferroni korrigált/korrigálatlan) a négy eseménytípus kiválasztott időintervallumaira 


\begin{tabular}{ll} 
Általánosan elfogadott angol rövidítések és mozaikszavak jegyzéke: \\
& \\
CAPM & Capital Asset Pricing Model \\
CAR & Cumulated Abnormal Return \\
CDP & Carbon Disclosure Project \\
CERCLA & Comprehensive Environmental Clean-Up and Liability Act \\
CERES & Coalition for Environmentally Responsible Economies \\
CRO & Corporate Responsibility Magazine (volt Business Ethics Magazine) \\
CSR & Corporate Social Responsibility \\
DJFB & Dow Jones Food Business Index \\
DJIA & Dow Jones Industrial Average \\
DJSI & Dow Jones Sustainability Index \\
DUNS & Data Universal Numbering System \\
EAP & Environment America Research and Policy Center \\
EMAS & Eco-Management and Audit Scheme \\
EMS & Environmental Management System \\
EPA & Environmental Protection Agency \\
ESG & Environmental, Social and Governance \\
ETC/SCP & European Topic Centre for Sustainable Consumption and Production \\
EUROSIF & European Social Investment Forum \\
GARCH & Generalized Autoregressive Conditional Heteroscedasticity \\
GEMS & Global Environmental Management Survey \\
GHG & Green House Gases \\
GMO & Genetically Modified Organism \\
GRI & Global Reporting Initiative \\
HDI & Human Development Index \\
ICID & International Commission on Irrigation and Drainage \\
IFIC & International Food Information Council \\
IFRS & International Financial Reporting Standards \\
IPCC & Intergovernmental Panel on Climate Change \\
KLD & Kinder, Lydenberg and Domini \\
NGO & Non-Governmental Organization \\
NPL & National Priorities List \\
NRDC & Natural Resources Defense Council \\
PERI & Political Economy Research Institute \\
SIC & Standard Industrial Classification \\
SRI & Socially Responsible Investing \\
TRI & Toxic Release Inventory \\
GAAP & Generally Accepted Accounting Principles \\
USSIF & United States Social Investment Forum \\
\hline
\end{tabular}




\section{BEVEZETÉS}

A 19. században megkezdődött nagyipari fejlődés alapvetően az erőforrások minél hatékonyabb kiaknázására és ezzel a nyereség maximalizálására épült. A 20. század utolsó harmadában azonban mind nyilvánvalóbbá vált, hogy ez a fejlődési pálya a természeti erőforrások ésszerủtlen mértékủ kiaknázásához vezet, és ennek következtében a fenntartható társadalmi és gazdasági fejlődés nem érhető el. Előtérbe került a megfelelő állami szabályozás fontossága és a felelős vállalati magatartás, illetve ezeknek a külső és belső irányelveknek a hatása a cégek költségeire és profitabilitására. A környezettudatos, fenntartható vállalati működés filozófiájáról könyvtárnyi irodalom született, de vajon a piac milyen mértékben és hogyan ismeri el a vállalatok ezen erőfeszítéseit? Megéri-e egy vállalatnak elköteleznie magát a felelős gazdálkodás mellett?

A vállalati környezeti teljesítmény kérdéskörének fontossága a gazdasági, tudományos és befektetői szektorban is jelentős mértékben növekedett. A központi kérdés, hogy az egyes vállalatok társadalmi teljesítménye - és többek közt ennek egy alkérdése a környezeti viselkedésük - hogyan függ össze a pénzügyi teljesítményükkel. Korábbi kutatások eredményei, melyek a vállalat társadalmi felelőssége és pénzügyi mutatói között kerestek összefüggést vegyesek voltak. Még az összefüggés iránya is tisztázatlan. Vajon a társadalmi felelősség vállalás az, ami magasabb profithoz vezet, vagy a magasabb profit az, ami lehetővé teszi ezen vállalatok számára, hogy többet fektessenek be ezen a területen?

A környezetvédelmi szabályozás hosszú évek óta jelen van, de általánosan elfogadott tény, hogy a környezetszennyezésre gyakorolt jótékony hatása nem igazán hatékony (DASGUPTA \& LAPLANTE 2001, ZSÓKA et al. 2005). Ez legfőképp annak tudható be, hogy a törvények betartatása illetve magának a nyomon követésnek a rendszere hiányos, illetve a kirótt büntetések mértéke messze nem elég a felelösök elrettentésére. A centralizált, direktív megközelítés elégtelennek bizonyult, ezért az elmúlt időszakban több piaci eszköz is létrejött (környezetvédelmi díjak, szennyezési jogok kereskedelme stb.), hogy szabályzó szerepet töltsön be. Számos közgazdász szerint azonban a leghatékonyabb az információ alapú szabályozás, amely részben a befektetői közösségre és a fogyasztókra támaszkodik a környezettudatos viselkedés nyomon követésére és betartatására (KONAR \& COHEN 1997, TIETENBERG 1998, BARON 2001). Ebböl a szempontból az információ - új szerepkörben - ösztönzöként hat a 
pénzügyi piacokon keresztül, hogy a vállalatokat környezettudatosabb viselkedésre kényszerítse. Nyilvánosan jegyzett vállalatok igazgatóitól, akik a részvényesi érték maximalizálására törekednek, elvárják azt is, hogy stratégiájukat hozzáigazítsák vállalatuk környezeti teljesítményének piaci értékeléséhez. Ez utóbbi mérésére leggyakrabban használt mutató a specifikus környezeti események hatása a vállalat tőzsdei árára. A tőzsdei árakban egy bizonyos időpontban bekövetkező változásokat, abnormális hozamokat, a kutatók az eseménytanulmány módszerével közelítik meg. Az esemény ez esetben a vállalattal kapcsolatos környezeti hír publikációja.

Kutatásom első fázisában a környezetvédelem és a fenntartható fejlődés általános fogalmaival illetve a témakör eddigi történetével ismerkedtem (ld. Disszertáció logikai felépítése 1. ábra). A szakirodalom áttekintése során érdeklődésem, pénzügyi beállítottságom és több mint tizenöt éves e téren szerzett tapasztalatom révén, a témakör gazdasági kihatásainak irányába terelödött. A közgazdaságtanban kialakult irányzatok tanulmányozásakor kirajzolódott két egymással rivalizáló szemlélet: egyesek számára a vállalatok környezettudatos müködésre fordított befektetései csupán plusz költségeket jelentenek, mások számára viszont versenyelönyt. A kérdés tehát, hogy van-e és ha igen, milyen a hatása egy vállalat környezeti teljesítményének annak tőzsdepiaci teljesítményére. Vizsgálataim második része ezért a társadalmilag felelős befektetés témakörére irányult. Ezen a téren az elmúlt tíz évben óriási változások történtek. A közhasznú szervezeteknek a vállalatok társadalmi szintű felmérésére irányuló kezdeti próbálkozásai után a témakört befektetői alapok karolták föl, tökéletesítették és rendszeresítették. Természetesen az etikus befektetési alapok fennmaradásának és sikerének alapfeltétele a jó pénzügyi eredmény. A vállalatok pénzügyi teljesítményét a tőzsdén elért eredményekkel mérik. A vállalatok társadalmi felelősségének felmérésekor három alapvető szempontot vizsgálnak: a társadalmi, a vállalatvezetési (etikai), illetve a környezetvédelmi aspektust. E három pillér közül disszertációmban a környezetvédelmi témára fókuszálok.

A fenntartható fejlődés és fogyasztás témakörét nézve szükségszerűen előtérbe került az élelmiszeripar e téren betöltött szerepe. Mind az ENSZ mind az Európai Unió kutatásai fokozottan foglalkoznak az iparág környezetünkre kifejtett hatásával (ETC/SCP 2009 és 2011). Ennek ellenére, a hazai és külföldi szakirodalmat áttekintve, eddig kevés tanulmány foglalkozott a környezeti és pénzügyi teljesítmény közötti összefüggések vizsgálatával az iparágban. Számos a vállalati társadalmi felelősség (Corporate Social Responsibility, CSR) területén tevékenykedő 
szakíró is felismerte, hogy az iparág jelentőségét tekintve ez a kutatási terület nagyobb figyelmet érdemelne (BARNETT 2007, HARTMANN 2011); és mivel az Egyetem profiljába is beleillik, kutatásom tárgyául az élelmiszeripart választottam.

A társadalmilag felelős befektetés Magyarországon még gyerekcipőben jár. Habár megfigyelhetöek egyes törekvések a vállalatok felmérésére (ld. ACCOUNTABILITY RATING HUNGARY 2006, 2007), a gyakorlat még korántsem annyira bevett, mint a fejlettebb tőzsdével és piaci kultúrával rendelkező országokban. Nagyobb gond, hogy a pénzügyi, de leginkább a környezeti mérőszámok a nyilvánosság számára nehezen hozzáférhetőek, nem standardizáltak és a legkevésbé sem rendszeresek. A Budapesti Értéktőzsde (BÉT) csak 1990-ben indult újra. Forgalom és a jegyzett vállalatok száma alapján is kis méretünek számít. A BUX súlyozás szerinti több mint 90\%-át mindössze négy nagyvállalat teszi ki (MOL, OTP, Richter, MTelekom). A jelenleg jegyzett ötvenhárom részvény közül csak egynek profilja az élelmiszeripar (Zwack). A környezeti hírekre adott piaci reakció mérésére alkalmazott esettanulmány módszer alapfeltétele a hatékony tőkepiac. Ennek hiányában az események hatása a vállalat értékére nem itélhető meg helyesen. A budapesti értéktözsde esetében sokszor a hatékonyság félig-erős formája sem áll fenn (részletes irodalmi áttekintést ld. MOLNÁR, 2006). A fentiekböl következik, hogy vizsgálataim alapjául csak nagy nemzetközi élelmiszeripari vállalatokat tudtam választani. Ezen vállalatok kimerítették információgyüjtésem három alapfeltételét: megfelelő hatékonyágú és méretű tőzsdén jegyzettek (esetemben a New York-in), mind pénzügyi mind nem pénzügyi paramétereik nyilvánosan hozzáférhetőek, illetve mindez több évtizedre visszamenőlegesen elérhetö.

Disszertációmban az élelmiszeripar környezeti teljesítményének média visszhangját és az ennek megfelelő piaci reakciókat vizsgálom különös tekintettel néhány pénzügyi és nempénzügyi vállalati szintủ mutatóra, illetve ezen reakcióknak időbeli alakulására az elmúlt két évtizedben. A vizsgálat tárgyának (élelmiszeripar), illetve időtartamának (az elmúlt két évtized) kiválasztásával a szakirodalom bizonyos hiányosságainak pótlására törekedtem, illetve azoknak a komplex összefüggéseknek a feltárására, melyek a környezeti hírekre adott tőzsdei reakciókat befolyásolják. Kutatásom célja feltárni, mely környezeti események eredményeznek szignifikáns tőzsdei reakciókat, mely cég specifikus mutatók befolyásolhatják ezeket a reakciókat, illetve, hogy változtak-e ezek a reakciók az idő függvényében. 


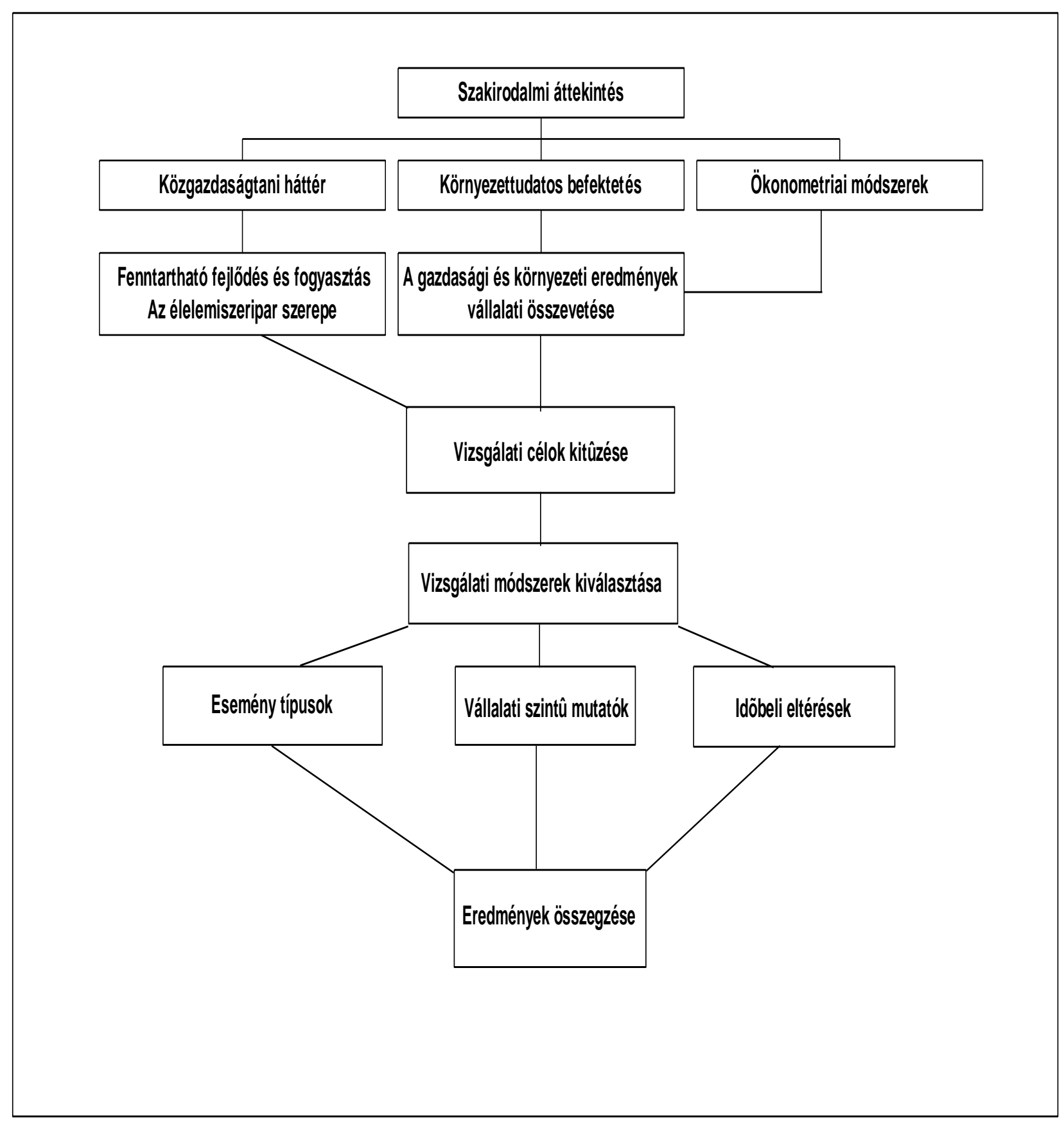

1. ábra. A disszertáció logikai felépítése 


\section{IRODALMI ÁTTEKINTÉS}

\subsection{A felelős vállalatirányítás és a fenntartható fejlődés}

A vállalatirányítás tradicionális meghatározása gyakran csak a pénzügyi teljesítmény javításának kérdésére, vagy a jogszabályok betartására korlátozódik. Munkámban tágabb értelmezést használok:

"A vállalatirányítás a gazdasági és társadalmi, valamint az egyéni és a közösségi célok közötti egyensúly megteremtésével foglalkozik. A vállalatirányítási keretrendszer célja, hogy ösztönözze a források hatékony felhasználását, valamint, hogy megteremtse a forrásokkal való gazdálkodásért fennálló felelősséget. A cél az, hogy az egyének, a társaságok és a társadalom érdekei a lehető legnagyobb összhangba kerüljenek."

(Sir ADRIAN CADBURY, Világbank, 2000)

Ez az un. felelős vállalatirányítás, melynek föbb céljai nem csak a versenyképesség és a jogszabályoknak történő megfelelés, hanem a hosszú távú eredményesség, fenntarthatóság és értékteremtés is.

A fenntartható fejlődés legismertebb definíciója az ENSZ Környezet és Fejlödés Világbizottságának 1987-es „Közös jövőnk” címü jelentésében található (Gro Harlem Brundtland, norvég miniszterelnöknő után „Brundtland jelentés”-ként is elhíresült). A jelentés szerinti definíció: „a fenntartható fejlődés olyan fejlődés, amely kielégíti a jelen generáció szükségleteit anélkül, hogy veszélyeztetné a jövő generáció esélyeit arra, hogy ők is kielégíthessék szükségleteiket" (THE WORLD COMISSION ON ENVIRONMENT AND DEVELPMENT, 1987). A Brundtland jelentést azért is fontos kiemelni, mert számos kutató véli úgy, hogy ez jelentette a fordulópontot a vállalati társadalmi felelősség (Corporate Social Responsibility, CSR) megítélésében (COHEN \& WINN 2007, HUETING 1990, SCHUBERT \& LANG 2005). Nem véletlen, hogy kutatásom is a kilencvenes évek fordulatát követő két évtizedet öleli fel. Hasonlóan ismert, még ennél is korábbi definíció HERMAN DALY megfogalmazása, amely szerint "a fenntartható fejlődés a folytonos társadalmi jólét elérése, anélkül, hogy az ökológiai eltartó-képességet meghaladó módon növekednénk" (DALY, 1973). 
Szintén a Brundtland Bizottság határozta meg a fenntartható fejlődés három alappillérét: a társadalmi, a gazdasági és a környezeti pilléreket. Eszerint mindhárom dimenziót együttesen, kölcsönhatásaik figyelembevételével kell mérlegelni, mivel a környezeti problémák megoldása nem lehet független a társadalmi valamint a gazdasági vonatkozásoktól. E három pillérnek a vállalati müködésre kivetített alkalmazása jelenik meg a vállalati társadalmi felelősség területén, ahol a vállalatokat környezeti, társadalmi illetve vállalatvezetési szempontok szerint is értékelik. 2001-ben az Európai Bizottság zöld könyve a CSR-t még a következő képpen definiálja:

“A vállalati társadalmi felelősségvállalás olyan törekvés, melynek értelmében a vállalatok önkéntes alapon üzleti tevékenységükbe integrálnak társadalmi és környezetvédelmi célkitüzéseket is, és ezen elvek mentén alakítják kapcsolataikat érintettjeikkel.”

(EURÓPAI BIZOTTSÁG, 2001)

A 2011-ben kiadott, bővített új meghatározásból azonban már hiányzik az „önkéntes” szó és a CSR-t „a vállalkozásoknak a társadalomra gyakorolt hatásuk iránti felelőssége”-ként értelmezik (EURÓPAI BIZOTTSÁG, 2011). Az új irányvonal nagyobb hangsúlyt helyez a multinacionális cégek átláthatóságára, illetve törekszik a magánszféra fokozottabb bevonására a környezeti és társadalmi problémák megoldásában. Fontos kiemelni, hogy hansúlyozottabb szerepet szánnak az etikus befektetői szférának is, és a megfelelő fogyasztói döntések, illetve a jó CSR megoldások elterjesztésének érdekében nagyobb nyilvánosságot sürgetnek.

Számomra, azonban a legátfogóbb és legrelevánsabb definíció kétségtelenül az ISO26000 CSR meghatározása:

„.... egy szervezet felelőssége döntéseinek és tevékenységeinek a társadalomra és a környezetre gyakorolt hatásáért, olyan átlátható és etikus magatartással, amely hozzájárul a fenntartható fejlődéshez, ide értve a társadalom egészségügyi és jóléti állapotát, figyelembe veszi az érintett felek elvárásait, megfelel az alkalmazott törvényeknek, összhangban van a nemzetközi magatartási normákkal, és ki van építve az egész szervezetben és a szervezet kapcsolataiban.”

(ISO, 2010)

A CSR tehát az üzleti siker elérését jelenti, de oly módon, amely egyúttal figyelembe veszi a társadalmi értékeket, a törvényi háttért, valamint a vállalat müködése által érintettek elvárásait is. A vállalatok környezeti teljesítményét nagyban befolyásolja a jogszabályi háttér (ennek szigora, következetessége és végrehajtatása), az érdekelt felek környezeti és társadalmi 
érzékenysége (társadalmi normák, közösségi elvárások) illetve a piaci tényezők (fogyasztók elvárásai, versenytársak hozzáállása). A vállalatok döntéseit e nyomásgyakorló felek komplex együtthatása alakítja. A vállalatok nem önmaguktól váltak egyik napról a másikra felelőssé, hanem mert egy részről a társadalom -lényegében a vevői és befektetői körük- megkövetelte, más részröl ugyanez a társadalmi nyomás a kormányokat is rákényszerítette, hogy egyre szigorúbb munkaügyi, egészségügyi, fogyasztóvédelmi és környezetvédelmi törvényeket hozzanak. A vállalkozások gazdasági (pénzügyi) sikerességét természetesen több tényező is befolyásolja a szüken vett vállalati tevékenységen (szolgáltatások és termékek előállítása) kívül. Az egyik ilyen tényező a vállalat imázs, amely korunk nyitott társadalmában egyre fontosabb szerepet tölt be. GÖRAN E. SJÖBERG, ATLAS díjas PR szakember, szerint „,.. a CSR a hírnév egyik fontos hatótényezője” (2005). SJÖBERG szerint a vállalati környezet jelenlegi fejlődése, illetve az érdekgazdák komplex hálózata miatt a CSR a hírnév-, motiváció- és kockázatmenedzsment alapvető eszközévé vált.

A fenntartható fejlődésről és felelős vállalati magatartásról alkotott fenti vélemények kialakulása hosszú folyamat volt, amely még ma is folyamatosan változóban van és korántsem egységes. Disszertációmban a jogszabályi megfelelésen túlmutató, információ alapú szabályozás szerepét kívánom közelebbröl megvizsgálni, kiemelve a környezeti és gazdasági pillérek együtthatását.

\subsection{Egymásnak ellentmondó teóriák, vagy egymást kiegészítő elképzelések?}

A vállalati környezeti teljesítmény jelentősége egyre növekszik az üzleti, tudományos és befektetői körökben. Az érdeklödés központjában az a vita áll, hogy egy vállalat környezeti tevékenysége hogyan befolyásolja annak pénzügyi eredményességét. Vajon egy cégnek, amely környezeti teljesítményének javítására törekszik, származik-e előnye ebből a vetélytársakkal szemben, vagy a jobb környezetgazdálkodás csupán extra kiadásokkal jár?

E tárgykörben két, látszólag egymással versengő, fö irányzat alakult ki: a statikus és a dinamikus szemlélet. Az első értelmezés szerint, ami a neoklasszikus mikroökonómián alapul, és amelyet tradicionális vagy költségorientált iskolának is neveznek, a környezeti befektetések költsége mindig meghaladja az abból származó hasznot. A másik, revizionista, vagy értékteremtőnek is nevezett iskola szerint a fenntartható fejlődés, mint hosszú távú stratégia 
számottevő előnnyel jár. Az első teória támogatói MILTON FRIEDMAN (1970) kutatásaira hivatkoznak. Sokan az ő nevéhez füzik az elhíresült szállóigét: "the business of business is business"1. Állítása szerint a cég egyetlen társadalmi felelőssége, hogy minél több profitot termeljen. Ezzel ellentétben, FREEMAN (1984) úgy gondolkodott, hogy ahhoz hogy egy cég legitimitást nyerjen társadalmi elhivatottság szükséges. Szerinte egy vállalat vezetői az összes érdekelt félnek pénzügyi felelősséggel tartoznak, és nem csak a részvényeseiknek. PORTER és van der LINDE (1995) ezt még egy lépéssel tovább vitték, azt hirdetve, hogy a társadalmilag felelös müködés versenyelönyhöz vezethet.

A közgazdaságtan elméletében a szennyeződés, mint külön fogalom, elsőként Arthur Pigou cambridgei professzor múvében jelenik meg. PIGOU a "The Economics of Welfare" (1920) c. munkájában a szennyeződést, mint a piacgazdaság kudarcának egyik lehetséges eredményét tárgyalja. Két fél közötti önkéntes cserék csak akkor történnek, ha mindkét fél hasznára szolgál az akció. A valóságban azonban az ilyen cserének sokszor nem szándékolt mellékterméke is keletkezik, ami egy harmadik felet érint. Az ilyen pozitív vagy negatív hatású mellékterméket externáliának (külső költség) nevezik. A társadalomra nézve a környezeti szennyeződés negatív externália, az üzleti döntések nem szándékolt következménye, amely kihat a döntéshozatalban nem szereplö felekre is. Ez gyakran etikai vagy politikai ellentétet szül. Elméletileg az externáliák problémájára válasz lehet, ha a magánszektort különféle ösztönzőkkel (adók) arra serkentjük, hogy tevékenységük teljes költségét magukra vállalják (internalizálják). Pigou szerint a kormány által kivetett adók mértéke, ha kiegyenlíti a károk miatti költségeket, megállítja az erőforrások nem hatékony felhasználását és jó hatást gyakorol a társadalom egészére. Eszerint a közgazdaságtani elmélet szerint a természet nem társadalmilag optimális mértékben történő átalakítása csupán egy piaci elégtelenségi, azaz hatékonysági probléma. A környezeti adóknak kettős haszna van, egyfelöl csökkentik a szennyeződést, másfelöl az adóbevételt magát is hasznosítani lehet. A versenyképesség szempontjából azonban a szennyező termékek előállítási költsége így növekszik, mivel az, amit korábban a társadalommal fizettettek meg, most az elöállítót terheli.

\footnotetext{
${ }^{1}$ A vállalat dolga az üzlet. A mondás valószínüleg eredetileg Alfred P. Sloan a General Motors ellentmondásos első emberének szájából hangzott el.
} 
Egy gazdasági tranzakció hatékonyságának legegyszerúbb meghatározása annak megállapítása, hogy az üzletben érintett felek egyike sem járt rosszul. Ez a jól ismert Pareto hatékonysági elv. A Pareto hatékonysági elv azonban nem veszi számításba sem az egyenlőséget sem az általános társadalmi hasznot. Lényegében, semmilyen önkéntes üzlet nem lehet Pareto szerint optimális, ha abban negatív externáliák foglaltatnak. A társadalmi cselekvés sajátos természetéből adódóan, például az állami környezetpolitika változása esetén, a társadalom valamely tagja mindenképpen rosszul jár. NICHOLAS KALDOR (Káldor Miklós) és JOHN HICKS (1939) a gazdasági hatékonyság kevésbé szigorú mérőeszközét javasolta, amelyben a társadalom jóléte az összesített szinten javul. Szerintük, ha egy lépésben benne rejlik a lehetőség, hogy optimálissá váljon, akkor annak megtétele jogosult. Ha egy üzletben B többet nyer, mint amennyit A veszít, akkor B választhatja, hogy kompenzálja A-t és még mindig marad nyeresége. A gyakorlatban a tényleges kompenzáció nem szükséges.

A kormányok a szennyeződés és a környezet kárositás egyéb problémáira válaszul törvényeket és rendeleteket alkotnak. A környezetpolitika hagyományosan ezen a közvetlen, direktív szabályozási (command-and-control) módszeren alapul. A közgazdászok azonban inkább a gazdasági vagy piaci eszközök alkalmazását, mint például a piacosítható szennyezési jogokat (tradable permit), a letét-visszafizetéses rendszereket (deposit-refund schemes), valamint az ökológiai szolgáltatások piacának létrehozását részesítik előnyben. Ezeknek az eszközöknek az a célja, hogy határozott költség alapú jelzést küldjenek a szennyezőknek és az erőforrások használóinak és ezáltal társadalmilag elfogadható magatartásra késztessék őket.

RONALD COASE a "Problem of Social Cost" c. munkájában (1960) arra a következtetésre jutott, miszerint a kormányok beavatkozása tulajdonképpen szükségtelen, mivel hatékony eredmény érhető el, ha az érintett felek képesek olyan kölcsönösen elfogadható szerződést létrehozni, amelyben kompenzálják egymást tevékenységükért. Coase szerint két megoldás lehetséges, vagy adót kell kiszabni illetve egyéb rendelettel korlátozni a szennyezőt, vagy a kárt szenvedőnek kell megfizetnie a szennyeződés okozóját, hogy az a szennyezést beszüntesse vagy lecsökkentse. Coase állítja, hogy az erőforrások hatékony elosztását tekintve, jóllehet a pénzügyi terhet más viseli, a végeredmény azonos. A Coase elv azonban bizonyos alapvető előfeltételeket igényel, mint a tulajdonjogok egyértelmü meghatározását, a felek racionális eljárását, és azt, hogy a tranzakciós költségek elhanyagolhatók legyenek. A gond az, hogy a valós pénzbeli érték gyakran nem határozható meg, és a tulajdonjogok sokszor nem 
tisztázottak. Ami pedig az ésszerü befektető problémáját illeti, az a gazdaságtan egy teljesen új területét képezi.

A 90-es évekig az volt az uralkodó nézet, hogy a kormány környezeti szabályozásából eredő veszteségek meghaladják az előnyöket és csökkentik a versenyképességet. Ez a vélemény azonban elvesztette népszerüségét, miután MICHAEL PORTER 1990-ben megjelentette "The Competitive Advantage of Nations" címü könyvét. PORTER később továbbfejlesztette elméletét az “America's Green Strategy” (1991) c. tanulmányában. A Porter Hipotézis (PORTER \& van der LINDE, 1995) szerint a szigorú környezeti szabályozás kiváltja a tisztább technológiák és környezeti fejlesztések felismerését és bevezetését. Ez az innovációs hatás hatékonyabb termelési folyamatokat és termékeket eredményez, egyúttal javítja az üzleti versenyképességet. Az elért költségmegtakarítás elég nagy ahhoz, hogy ellensúlyozza nem csak azokat a költségeket, amelyek közvetlenül az új szabályozásnak vagy az innovációnak tulajdoníthatók, hanem nyereséghez is vezet. Az a vállalkozás, amely felismeri a környezeti elkötelezettségben rejlő lehetőségeket és elsőként hasznosítja az innováció előnyeit a tanulási görbe és szabadalmazás révén, vezető versenyhelyzetbe kerül azon országok vállalataival szemben, ahol a környezeti szabályozást jóval később vezették be.

Porter hipotézisével szemben Palmer és munkatársai (PALMER, OATES et al. 1995) úgy vélik, hogy a környezetvédelmi szabályozásnak megfelelés és a versenyképesség között mindig van egy szükségszerü kompromisszum (trade-off). Ha egy vállalatnak korábban nem érte meg, hogy környezeti innovációba fektessen be, akkor, amikor szigorúbb előírásokat vezetnek be a haszna már nem lesz elég, hogy teljesen fedezze a megfelelés költségeit, vagyis a környezeti befektetések negatív nettó jelen értékhez fognak vezetni. Jaffe szerint (JAFFE, PETERSON et al. 1995) az átváltás (trade-off), nem azért túlértékelt, mert a cég az innovációból haszonra tesz szert, hanem mert a környezeti szabályozás, az alacsony megfelelési költségek miatt, nem jelent eléggé szigorú visszatartó erőt.

Még ha a vállalati társadalmi teljesítmény és a pénzügyi teljesítmény közötti összefüggést el is fogadjuk, annak mögöttes okai kérdésesek. WADDOCK és GRAVES (1997) szerint valószínüsíthető, hogy az egyes társadalmi dimenziókban elért jobb eredmények, mint a javuló környezeti jellemzők, és a jobb pénzügyi eredmények között létezik összefüggés. Azonban az erőforrás feleslegek teóriáján alapulva (slack resources theory) úgy vélik, hogy a pénzügyileg sikeres cégek több forrással rendelkeznek, amit társadalmi ügyekre költhetnek, és ez a sikeresség 
egyúttal magasabb színvonal elérésére is ösztönzi őket. A másik oldalon a helyes vállalatvezetés (good management theory) támogatói állnak. Ez az érdekelt felek elvén alapul (stakeholder theory, FREEMAN 1984), amely szerint a vállalatvezetésnek számos csoport érdekeinek kell megfelelnie, amelyeknek valamilyen "része" van a vállalatban, és befolyásolhatják annak jövőjét (2. ábra). A vállalati pénzügyi teljesítményt tekintve ezért bölcs döntés a vállalati társadalmi felelősségben (CSR) való részvétel, hogy ez által az érdekelt felek további, jövőbeli támogatását biztosítsák.

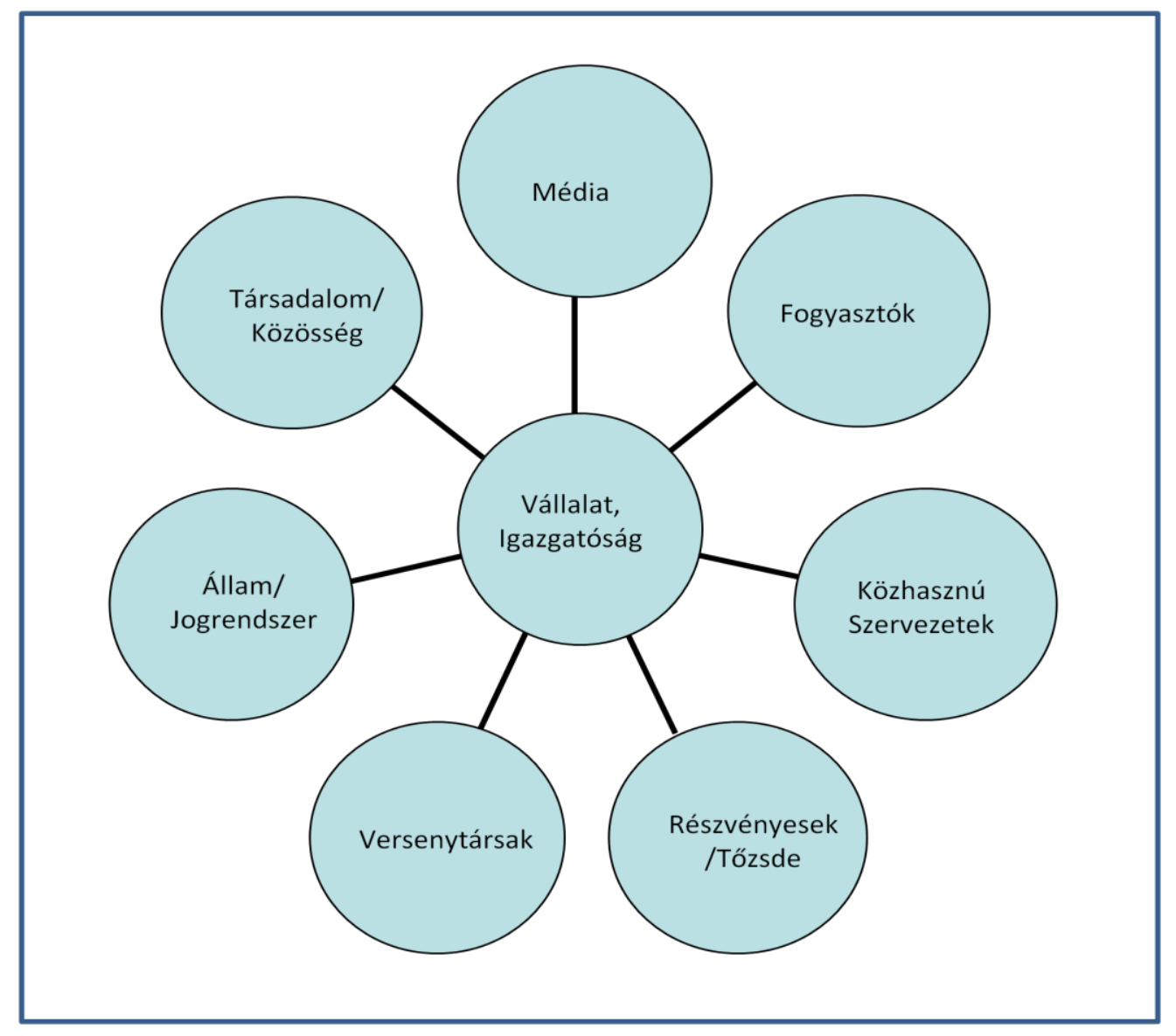

2. ábra Az érdekeltségi körök összefüggése

Egyszerüsitett keretrendszer Freeman után, saját szerkesztés

Az utóbbi időben a CSR témakörben napvilágot látott - és különösen a CSR tevékenység pénzügyi hasznosságát fejtegető - értekezések a fentiekben taglalt teóriák holisztikusabb megközelítését szorgalmazzák (MAROM 2006, GARCIA-CASTRO et al. 2010, SCHRECK 2011). Eszerint a társadalmilag felelös üzletvezetés nem zárja ki a profitabilitást, de nem mindegy, hogy ki, mikor és milyen CSR tevékenységet folytat. Emellett a rendkívül összetett 
rendszerből adódó nagymértékü endogenitás miatt, az inputok és outputok állandó kölcsönhatásban állnak egymással, vagyis egy tevékenység pénzügyi eredményessége nagyban függ a vállalat mindenkori helyzetétől. A vállalati tevékenységet ezért a változó körülmények tükrében kell vizsgálni, és csak is egy hosszú távú stratégia részeként, ellenkező esetben félrevezető következtetésekhez juthatunk. Végeredményben tehát Sloan-nak igaza volt; a vállalat elsődleges célja a nyereség, de ha körülmények azt követelik - mint jelenlegi nyitott, rendkívül összetett társadalmunkban, kiélezett versenykörülmények között - Porternek is igaza van, és a nyereséghez vezető utat sokszor a társadalmilag felelős müködésen keresztül szerzett plusz előny jelentheti.

\subsection{A környezettudatos befektetés}

\subsubsection{Mi az a társadalmilag felelős befektetés?}

Az elmúlt tíz évben néhány tucatról több mint kétszáz fölé emelkedett a társadalmilag felelős befektetői társaságok (Socially Responsible Investing, SRI) száma (EUROSIF, 2010). Ezek a társaságok olyan vállalatokba fektetnek be, amelyek egy részről a környezetvédelmi és társadalmi vétségekből adódó fizetési kötelezettségeiket, vagyis az ebből eredő perek és büntetések költségeit, a minimumon tudják tartani, más részről olyan termékeket és szolgáltatásokat állítanak elő és olyan módon, amelyek megegyeznek a társadalmilag érzékeny befektetők elképzeléseivel.

A vállalati társadalmi felelősség, és ennek a tőzsdére és a vállalatok értékelésére is kiható, u.n. etikus befektetési mozgalom kezdetét (Socially Responsible Investing vagy SRI) a dél-afrikai Apartheid kormány elleni 1980-as évekbeli akcióktól számítják. Ez volt az első alkalom, hogy átfogó gazdasági kampány indult egy bizonyos ügy (az Apartheid megszüntetése) érdekében, aminek eredményeként egyes befektetők, és az őket képviselő társaságok befektetői szürőket kezdtek el használni. Amikor 1993-ban Nelson Mandela az ENSZ előtt bejelentette, hogy a dél-afrikai szankcióknak immár véget lehet vetni, sokan az etikus befektetés végét jósolták. De nem így történt. Idöközben az ötlet ugyanis sok más társadalmilag érzékeny befektetőben is felébresztette az érdeklődést és a befektetési alapok is felismerték, hogy az ilyen pénzeszközöknek piaca van. Megjelentek a sokrétegű etikus alapok, melyek már a dohány, 
alkohol, fegyvergyártás, szerencsejáték, nukleáris energia stb. kiszürésére specializálódtak. Ehhez kapcsolódtak azután a szárnyaikat próbálgató környezetvédő szervezetek, amelyek több nagy nyilvánosságot és felháborodást keltő ügy kapcsán (pl. Exxon Valdez katasztrófa, bálnavadászat, bhopali baleset, Three Mile Island incidens) egyre fokozottabb támogatottságot nyertek.

Az elmélet egyszerü: a piacot fel lehet használni, hogy a vonakodó vállalatokat jobb útra kényszerítsék. Ezek a befektetők már nem csak azt várták el, hogy a cégek jövedelmezőek legyenek, de azt is, hogy mindezt társadalmilag felelős úton érjék el. A közvélemény pozitív befolyásolásában fontos szerepet játszanak az önszerveződő (u.n. "grass root”) és közhasznú szervezetek, amelyek jól kihasználták a nyílt média és az állami intézmények nyújtotta lehetőségeket. A közhasznú szervezetek (NGO, Non Govermental Organizations) egyre fontosabb szerepkört kezdtek betölteni kihasználva a közvélemény nagyvállalatokkal és kormányokkal szembeni gyanakvását, illetve ezek tehetetlenségével való elégedetlenségét. Az első, 1970. április 22.-én megrendezésre került Föld Nap (Earth Day), amely több mint 20 millió amerikait hozott össze országszerte, ráébresztette a környezetvédőket, hogy nincsenek egyedül és széles társadalmi támogatottság áll mögöttük, a politikusok pedig hirtelen lépéshátrányban találták magukat.

Eleinte a befektetői szürők többnyire csak valami ellen szóltak, de ahogy a mozgalom fejlődött mind többen kezdtek pozitív szürőket is használni, tehát nem valami ellen, hanem valami mellett szavaztak a dollárjaikkal. A pozitív visszacsatolás eszköze sokszor sokkal hatékonyabbnak bizonyult a vállalatok megfelelö irányba terelésére. Nemcsak hogy nem fektettek be olyan vállalatokba, amelyek nem érték el az általuk egyre magasabbra helyezett mércét, de megjelentek az igazgatói üléseken, felhasználták részvényesi szavazataikat, és határozatokat hozattak.

Az 1990-es évekre a vállalatok körében is egyre inkább elfogadottabb lett, hogy a környezetvédelemre ne, mint szükséges rosszra, hanem mint a versenyelőny hosszú távú megtartásának lehetőségére tekintsenek, megjelent a fenntartható fejlődés fogalma. A progresszív vállalatok rájöttek, hogy a környezettudatos gazdálkodás csökkenti a költségeket, jobb minőségü és piacképesebb terméket és kevesebb kötelezettséget eredményez, ráadásul egy társadalmilag egészséges környezet létrehozásával a vállalat imázsát is javíthatják nem csak dolgozóik, és a helyi közösség, hanem befektetői illetve vevői körükben is. Egy-egy nemzetközi 
nagyvállalat sokszor több befolyással és tőkével rendelkezik, mint egyes államok. Amikor egy McDonalds vagy egy Coca-Cola a fenntartható fejlődés mellett kötelezi el magát, akkor beszállítóinak környezetvédelmi gyakorlatát is befolyásolhatja, nem is beszélve a dolgozóinak képzéséről vagy a helyi közösségi programokról.

A kezdeti „mézeshetek” elmúltával, miután cégek felfedezték a „zöld” fogyasztókat, az is nyilvánvalóvá vált, hogy az egyszerủ szemfényvesztés u.n. „greenwashing”, már nem müködik. A globalizációval egy időben ugyanis beköszöntött az információs korszak. A vevők és egyben a befektetők is, különösen a fiatalabb generáció, mind tájékozottabbá váltak. Többé nem érte meg nem létezö „zöld” múltat kitalálni vagy termékeiket környezetbarátként feltüntetni. A fogyasztók felnőttek és velük együtt nőtt a fogyasztóvédelem és az őket támogató állami szervek és törvények szerepe is.

\subsubsection{Tendenciák a társadalmilag felelős befektetés piacán}

Drámaian megemelkedett azon befektetők száma, akik fenntarthatósági és környezeti, társadalmi és vállalatvezetési (Environmental, Social and Governace, ESG) szempontokat is bevonnak portfólió konstrukcióikba. A globális SRI piacot 2010-ben kb. 7,6 trillió euróra becsülték, melynek legnagyobb részét Európa tette ki (3. ábra).

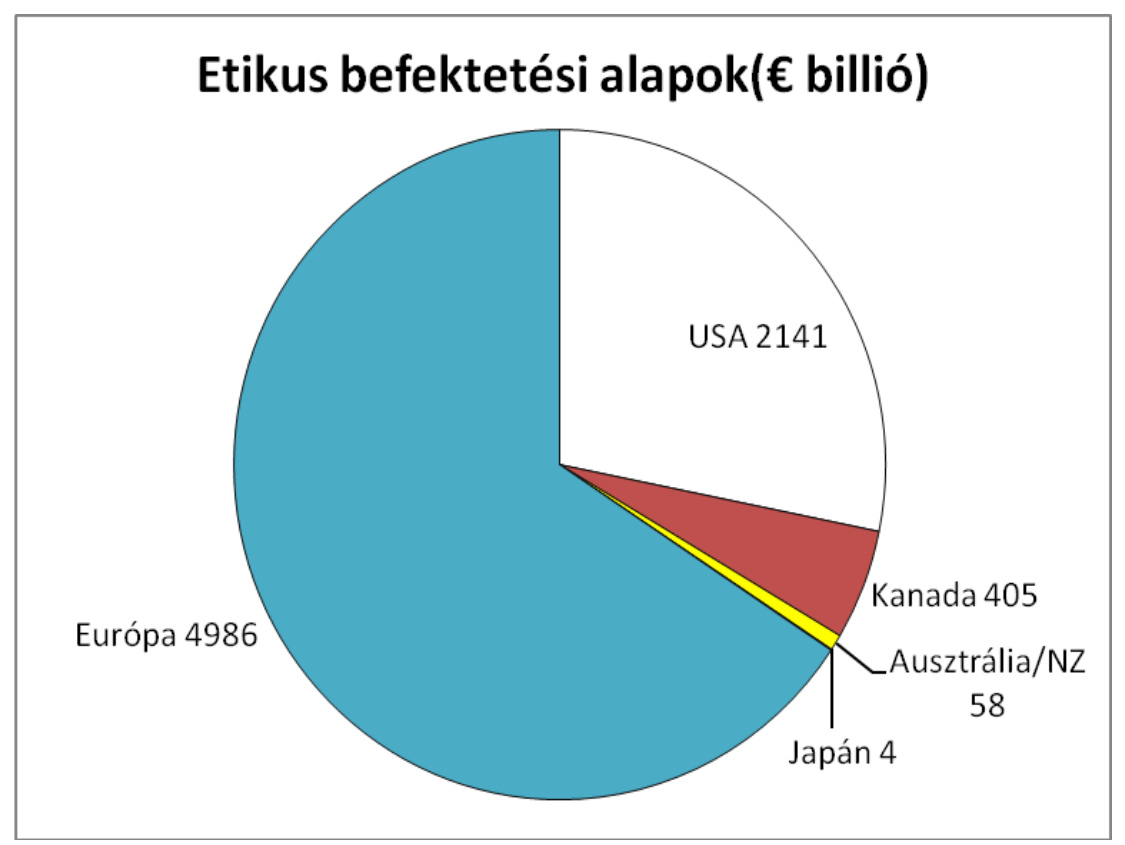

3. ábra Az etikus befektetési alapok piaca, 2010

Forrás: (EUROSIF, 2010) 
Az A. T. Kearney tanácsadó cég 2008-as felmérése alapján, azon vállalatok tőzsdei hozamai, amelyek a fenntartható fejlödésre fókuszáltak, a gazdasági válság kezdetekor mért hat hónapos periódusban átlagosan 15\%-kal teljesítették túl az ugyanazon iparágban lévő, de nem zöld orientált vállalatokat (A.T.KEARNEY, 2009). A Social Investment Forum 2009-es adatai hasonlóan pozitív eredményeket mutatnak a különböző etikus befektetési alapok (KLD, Calvert, Domini stb.) hozamaira (4. ábra).

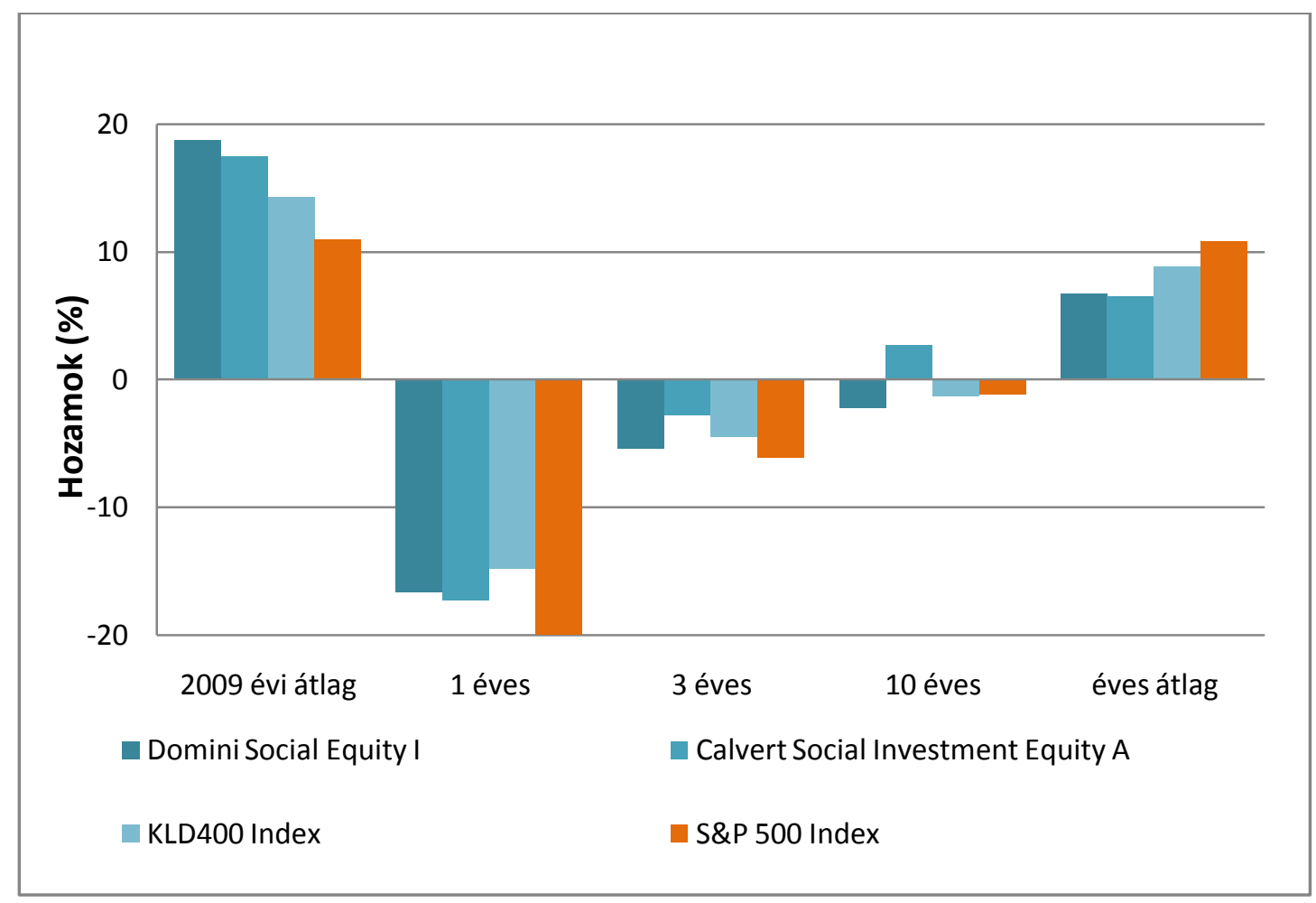

4. ábra Az etikus befektetési alapok teljesítménye vs. S\&P500

Forrás: Social Investment Forum Foundation (USSIF), 2009

Az etikai befektetési alapok bebizonyították, hogy az etikus alapokon nyugvó szelekció nincs negatív kihatással a tőzsdei értékhozamokra, sőt legalább olyan szinten képesek teljesíteni, mint a tőzsdei átlag. Még az elmúlt időszak gazdasági válsága során is megállták a helyüket, kevésbé negatív tőzsdei hozamot produkálva, mint társaik. A társadalmilag felelős befektetés egy olyan koncepció, amely folyamatosan fejlődik, ahogy a pénzügyi szolgáltató szektor egyre újabb módszereket fejleszt ki a környezeti, társadalmi és vezetési kritériumok befektetői alapokban való alkalmazására. 


\subsection{A média szerepe}

Társadalmunkban ma a média nélkülözhetetlen szerepet tölt be. Szórakoztat, tájékoztat és irányadóként müködik a vélemények kialakításában. Befolyásolja az emberek cselekedeteit, és az elmúlt években más tradicionális intézmény, mint az állam, oktatás vagy egyház, szerepkörét is átvette. A jelenlegi átlátható, nyílt társadalomban, a környezetvédelmi katasztrófák nagyfokú nyilvánossága miatt, közismert vállalatoknak különösen hosszan tartó és hatalmas pénzügyi és társadalmi következményekkel kell szembe nézniük. A technológia és média fejlődése az etikus befektetők döntéseiben is fontos szerepet játszik. A 2010 áprilisában bekövetkezett Deepwater Horizon olaj katasztrófa (British Petróleum) ismételten arra emlékeztette a befektetőket, hogy milyen fontos a tőzsdei papírok kiértékelésébe környezetvédelmi kockázati szempontokat is belevonni. Ez a baleset ugyanis világszerte komoly pénzügyi gondokat okozott a befektetéseikből élő nyugdíjasok millióinak.

$\mathrm{Az}$ önszerveződő (u.n. "grass root”), és közhasznú szervezetek által támogatott fenntarthatósági témakör fokozott figyelmet kap, nemcsak a fejlődő országokban, hanem globálisan is. Az idevágó cikkek száma ugrásszerűen megnövekedett a nyomtatott sajtóban (5. ábra), és jó néhány környezetvédelmi érdeklődési körü magazin is megjelent a piacon.

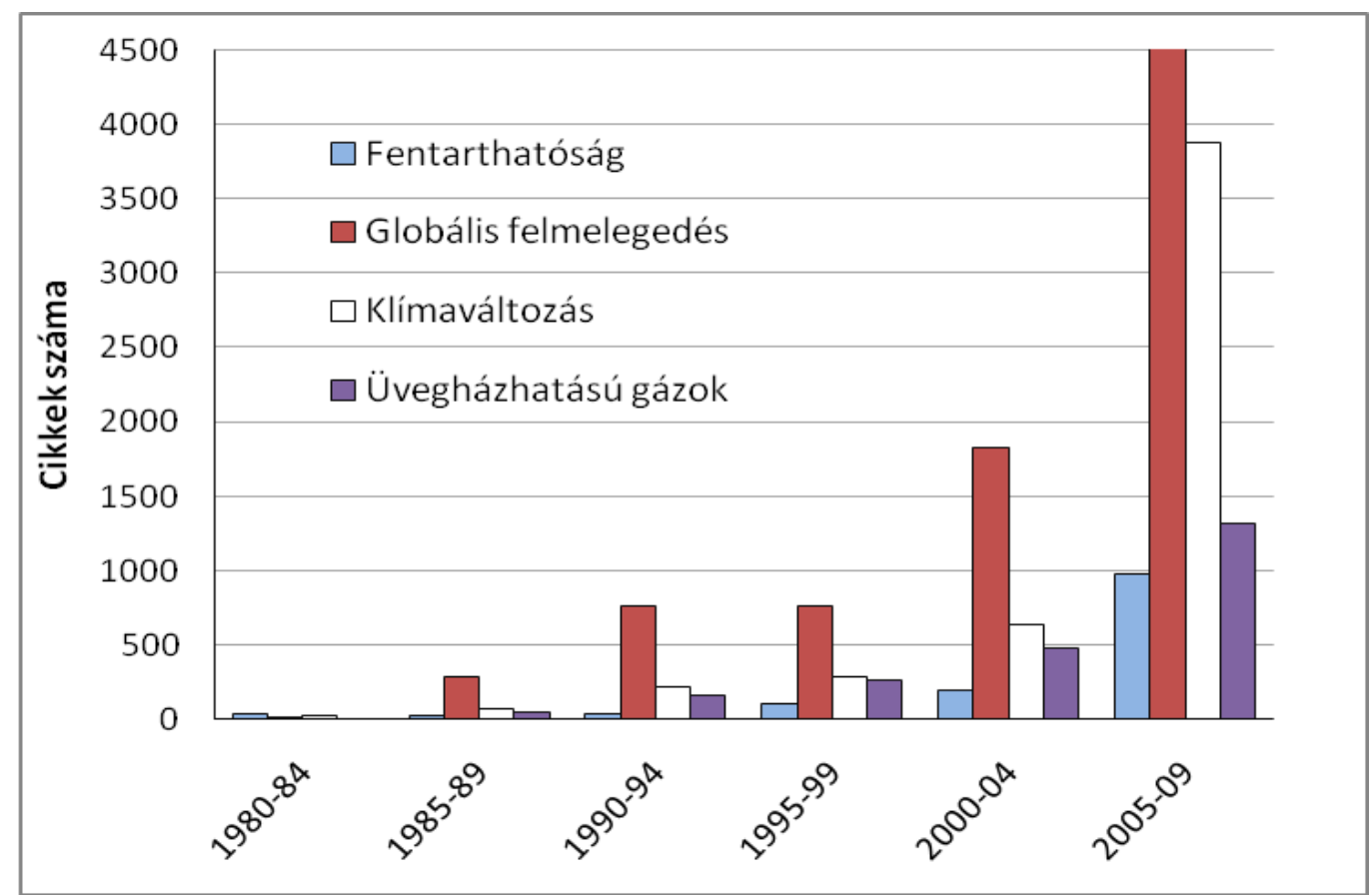

5. ábra Környezetvédelmi témájú cikkek a New York Times ban, 1980-2009 Forrás: The New York Times, saját kutatás 
Az elmúlt évtized fejleménye az internet és mobil telefon olyan szintü elterjedése, ahol már nem csak a hivatalos média, hanem magánszemélyek is bárhol, bármikor képesek helyzetjelentéseket percek alatt akár milliókhoz is eljuttatni. Több aktivista szervezet is igyekszik kiaknázni a fiatal szavazók körében rendkívül népszerü különböző társas weboldalakat. A Facebook oldalain például a legnépszerübb a több milliós tagságú „Stop Global Warming” (Állítsátok Meg a Globális Felmelegedést!) nevű weboldal. A televízió is egyre gyakrabban foglalkozik környezetvédelmi ügyekkel, sőt még kimondottan fenntarthatóság témájú csatornák (ld. pl. Magyarországon Ozon Network) is létrejöttek. A média, és ennek egy különös kinövése a hírességek (celebrities), rendkívül fontos szerepet játszanak a társadalomban. Egy-egy híresebb közéleti személyiség milliókat állíthat az ügyed mellé, vagy fordíthat ellened. Mind a modern technológia mind egy megfelelő példakép ügynek biztosított támogatása fontos szerepet játszanak a fenntartható fogyasztási szokások és egészséges életmód fiatalok körében történő népszerüsítésében.

A vásárlók sokszor a médián keresztül szerzik tudásukat a környezetvédelemről, a média pedig legtöbbször környezetvédelmi csoportokra és szervezetekre támaszkodik információszerzés céljából. Egy 2005-ös Eurobarométer felmérés szerint az európaiak többsége az NGO-kat tartotta a legmegbízhatóbb forrásnak környezetvédelmi információk szempontjából, míg a médiát (beleértve a tv-t, rádiót és nyomtatott sajtót) a második helyen említették (EUROBAROMETER, 2005). Maguk a vállalatok utolsóként kullogtak (a válaszadóknak mindössze 3\%-a tartotta öket megbízhatónak).

Elszaporodtak azok a publikációk is, amelyeket különböző kutató intézetek, nonprofit szervezetek és befektetési alapok hoznak nyilvánosságra. A tanulmányok többféle szempont szerint rendszerezik és értékelik a vállalatok CSR teljesítményét, górcső alá véve azok minden aspektusát. Ezek a jelentések aztán megfelelő média figyelmet kapva pl. a Newsweek hasábjain vagy a CNN riportjaiban tünnek fel és több millió potenciális vásárlót és befektetőt érnek el. A vállalatok számára ezért létfontosságúvá vált, hogy fokozott figyelmet fordítsanak média kampányaikra és a vállalati imázs befolyásolására. 


\subsection{Magyarországi helyzetkép}

Habár , disszertációm a már korábban tárgyalt okok miatt, nem a magyarországi vállalatokra fókuszál, szükségesnek tartottam, hogy egy rövid összefoglaló erejéig foglalkozzam az itthoni helyzettel is. Ez a rövid kitérö azonban újabb hiányosságokat tárt fel környezettudatos vállalati magatartás illetve, az ezt támogató etikus befektetések terén.

\section{A termelési oldal}

A GEMS (Global Environmental Management Survey) kiadványa szerint hazánkban a környezeti kommunikáció fejlettségének indexe, amely mutatja, hogy mennyire tudják kihasználni a környezettudatos vállalati müködés pozitív imázs javító hatását a vállalat külső kommunikációiban, igen alacsony (6.ábra). A felmérés 344 klasszikus ipari gyártó céget foglalt magába. A GEMS 1999-es tanulmányát azóta sem követte újabb felmérés hazánkban.

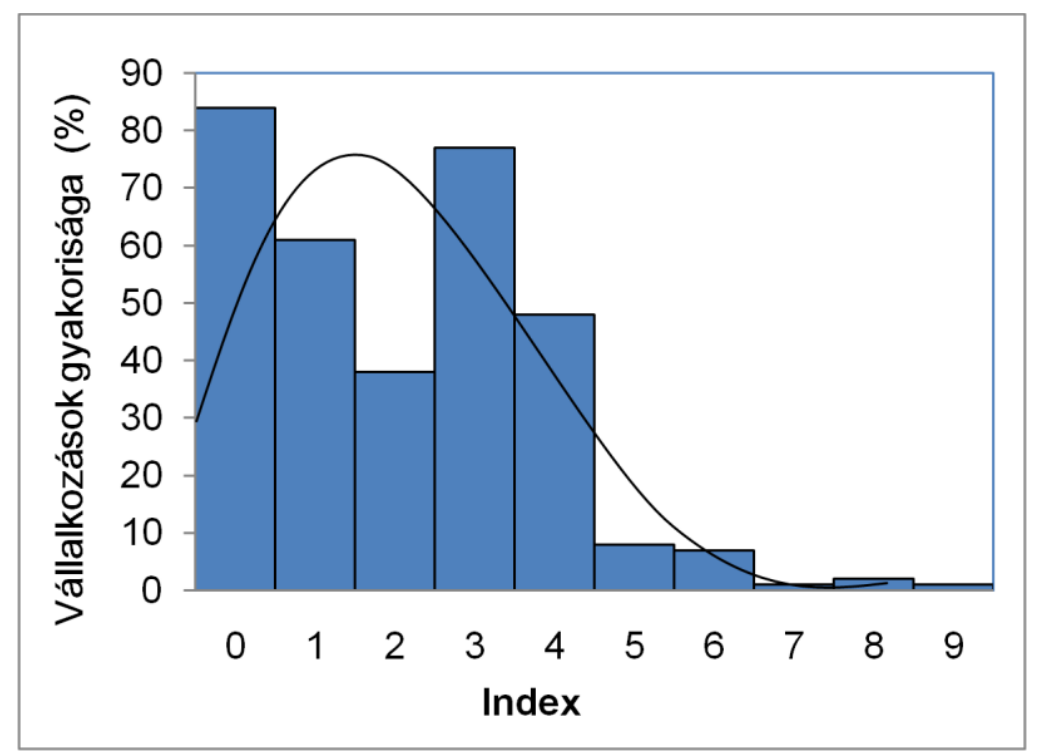

6. ábra A környezeti kommunikáció fejlettségének indexe Magyarországon

Forrás: Global Environmental Management Survey, 1999

A magyar élelmiszeripari ágazatra tekintve egy 2004-es OECD felmérés jó néhány hiányosságot tár fel (OECD, 2004). A vállalatok környezetirányítási szintje (KIR), vagyis hogy a 
rendelkezésre álló különféle környezetirányítási menedzsment eszközökből (mint környezeti jelentések, zöld számvitel, auditok, környezeti mutatók stb.) mennyit vesznek igénybe, a vállalatok többségénél alacsony volt (7. ábra). A vállalatoknak mindössze 12\%-a rendelkezett környezetvédelmi irányítási rendszerrel (ISO 14001, EMAS) és csak 20\%-uk mérte a globális mérgező anyagok kibocsátását.

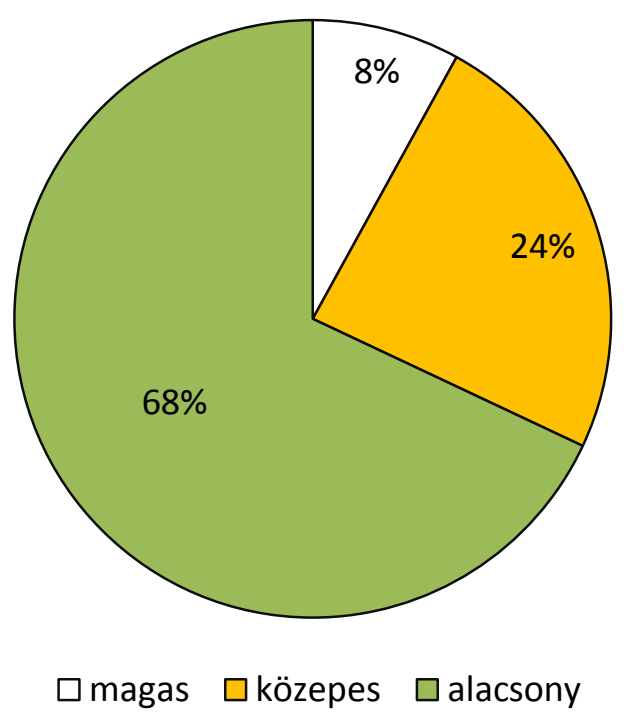

7. ábra Környezetirányítási rendszerek használata a magyarországi élelmiszeriparban Forrás: OECD felmérés, 2004, saját szerkesztés

A Gazdaság Kutató Intézet (GKI, 2010) felmérése szerint, amely több mint ezer különböző ágazatba tartozó vállalkozást ölelt fel, a legtöbb magyar vállalat (majdnem 60\%) nagyon fontosnak tartja a környezetvédelmet és úgy véli ágazatán belül átlagon felüli a környezeti érzékenysége (80\%). Állításuk szerint a CSR tevékenységek fö motivációs tényezője a vállalat imázsának javítása (a környezetvédelem csak a nyolcadik a listán). A fenti állítások nem összeegyeztethetőek azzal a ténnyel, hogy a magyarországi vállalatok CSR kiadásai minimálisak. A megkérdezettek 77,5\%-a egyáltalán nem és 9,4\%-a pedig alig fordít az egyes CSR-tevékenységek hirdetésére. Ugyanakkor beszerzéskor csak mintegy 10\%-uk veszi figyelembe a beszállító környezetvédelem iránti elkötelezettségét. Ez a felmérés, a 2004-es OECD beszámoló után hat évvel, már 30\% körülire teszi a valamilyen környezetvédelmi irányítási rendszerrel (ISO 14001, EMAS) bíró vállalatok számát. A vizsgált vállalatok 74\%ákánál nem merül fel semmiféle környezetvédelemmel összefüggő, önkéntes környezeti költség. 
A CSR tevékenységek külső kommunikációjára a megkérdezettek 77.5\%-a egyáltalán nem költ, és $67.3 \%$-uk még a belső alkalmazottak felé sem kommunikál.

\section{A fogyasztói oldal}

A fogyasztói oldalon a Medián Közvélemény és Piackutató Intézet, 2005-ös és 2006-os felmérése szerint a megkérdezettek többsége a vállalatokról alkotott vélemények kialakítása során a leghitelesebb információforrásként a médiát említette, a második helyezést pedig a független, globálisan elismert, társadalmi és környezeti teljesítményt összehasonlító vállalati rangsorok érték el. A vállalati felelősség lehetséges ösztönzőjének mindenekelőtt a jogi szabályozást (benne EU-s szabályozást) tartották. Másodikként mindkét évben a nyilvánosság szerepelt, de érdekesség, hogy a két lekérdezés közül a második felmérésben - a CSR téma sajtóban mind gyakoribb feltünése miatt - az ezt választók aránya emelkedett.

Általában véve Magyarországon még mindig nem léteznek publikusan hozzáférhető adatbázisok, melyeken az egyes vállalatok környezeti teljesítményéről lehetne tájékozódni és nagyon kevés vállalatnak van internetes CSR weboldala. Habár 2010-ben már kelet európai országok is képviseltették magukat az Európai Fenntartható Befektetői Fórumon (European Sustainable Investment Forum, EUSIF), Magyarország ez idáig még nem csatlakozott az etikus befektetők közösségéhez (EUROSIF, 2010). Néhány magyarországi bank ajánl ugyan u.n. zöld befektetési alapokat, de ezek mindegyike lényegében külföldi befektetői alapok termékeire épül. Sem a nonprofit szervezetek sem a tőzsdei befektető alapok nem játszanak olyan jelentős szerepet, mint a fejlettebb nyugati országokban, így a magyar vállalatokról rendszeresen végzett és publikált részletes felmérések sem léteznek. A már korábban említett Accountability Rating Hungary által kezdeményezett vállalati rangsor, melyet 2007-től a budapesti székhelyü Braun \& Partners tanácsadó cég vett át, a megfelelő irányba tett lépés, de sokkal több hasonló, a vállalatok CSR teljesítményének objektív felmérésére irányuló, kezdeményezésre lenne szükség.

A környezettudatos, és társadalmilag felelős fogyasztói réteg kialakulása nagyban függ az ország társadalmi és gazdasági fejlettség szintjétől. Elsődleges feltétel, hogy kialakuljon egy olyan fogyasztói réteg, amelynek legfőbb célja már nem csak az alapigények kielégítése (ld. Maslow szükségletek hierarchiáját) hanem magasabb társadalmi célok elérésére is törekszik. Az ilyen társadalomban előtérbe kerülhetnek az egészséges életmód, társadalmi érzékenység és környezetvédelem témakörei. Egy társadalmilag fejlett, demokratikus környezetben pedig 
irányadó az egyéni felelősségvállalás, és a lentről felfelé irányuló kezdeményezések. Jól tudott, hogy az egy lakosra jutó bruttó hazai termék a gazdaság teljesítőképességéről ugyan tájékoztat, de a lakosság tényleges életkörülményeiröl nem. Az elmúlt évtizedben ezért terjedt el az emberi fejlődés indexe (Human Development Index) mely iskolázottsági, egészségügyi, foglalkoztatási adatokat is tartalmaz. Az ENSZ által évente publikált Humánfejlettségi jelentés (Human Development Report) alapján Magyarország 2005-re érte el azt a társadalmi-gazdasági fejlettség szintet, amin pl. az USA volt az 1970-es években, amikor ott a környezettudatos, fenntartható fejlődési folyamat elindult (8. ábra). Az 1990-es évek elején megindult felfelé ívelő trend azonban itt meg is állt és az utóbbi években, különösen a világméretủ gazdasági válság óta, nem tapasztalható jelentős javulás.

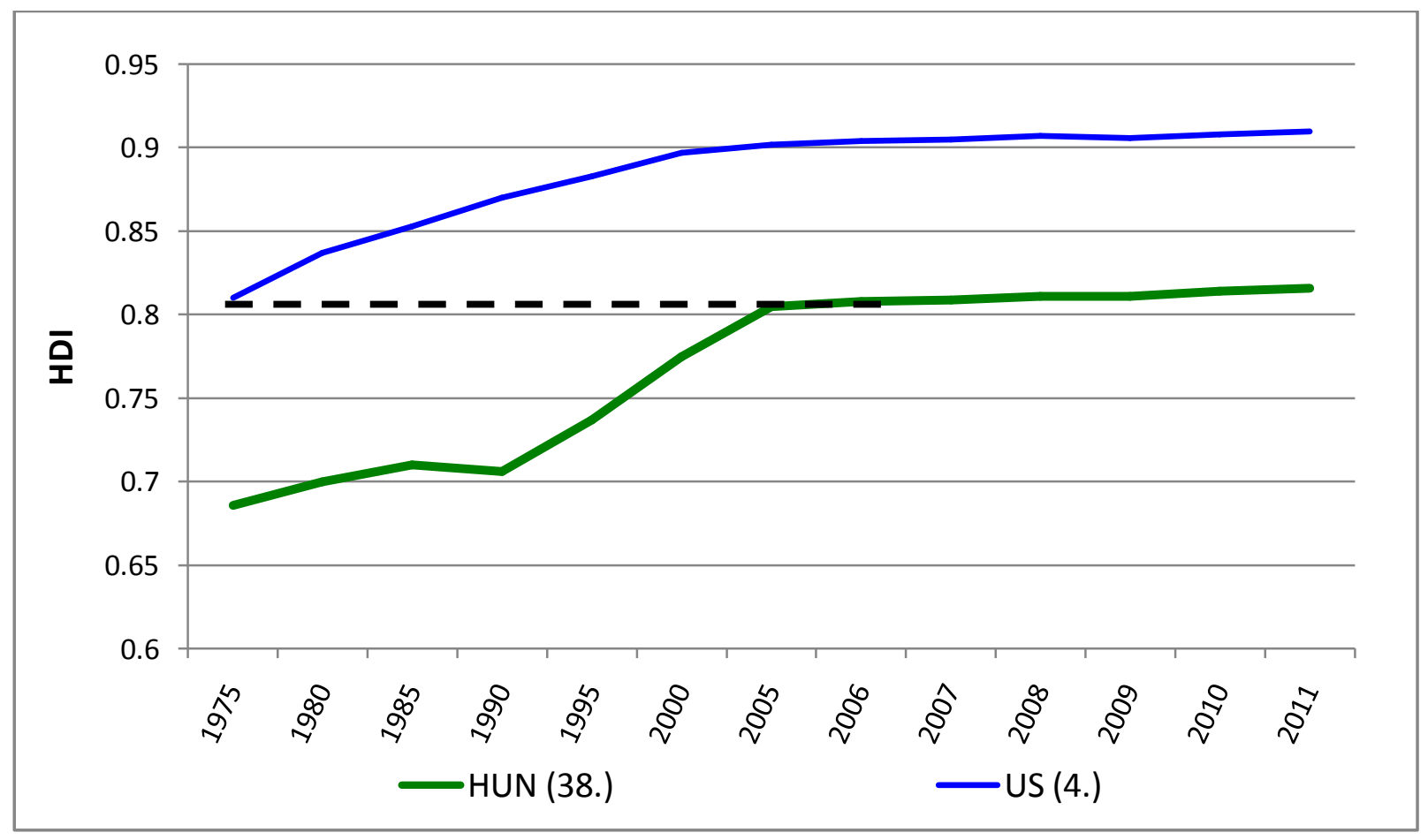

8. ábra A Humánfejlettségi Mutató (Human Development Index, HDI) alakulása Magyarországon (HUN) és az Egyesült Államokban (US) Forrás: Human Development Report, United Nations Development Program (2011)

Az utóbbi időkben megfigyelhető a fenntartható életmód és az ehhez kapcsolódó viselkedésminták elterjesztésre irányuló médiakampányok megjelenése, amelyeknek nyilvánvaló célja a fogyasztók környezet- és egészségkultúrájának fejlesztése. Nem elég azonban az igényt felébreszteni a fogyasztókban, hanem az ehhez szükséges eszközöket és lehetőségeket is biztosítani kell számukra. 


\subsection{Globális tendenciák a nemzetközi élelmiszeriparban}

Az élelmiszeripar több szempontból is kiemelt jelentőségü. Az élelmiszer elsősorban létszükséglet és a biztonságos és elégséges élelmiszerellátásnak legalább akkor nemzetbiztonsági szerepe van mint az energiaellátásnak. Emellett az élelmiszertermelés nemcsak befolyásolja de nagy mértékben függ is a környezettől. Az élelmiszeriparnak különböző kihívásokkal kell szembenéznie, melyek nem csak a pénzügyi eredményességet, hanem az imázst és hosszú-távú életképességet is befolyásolják (2. táblázat). Az érdekelt felek a felelős vállalatvezetés részeként elvárják az élelmiszertermelő cégektől, hogy korunk égető környezeti és társadalmi problémáinak megoldásában ők is aktívan részt vállaljanak.

2. táblázat Globális tendenciák a nemzetközi élelmiszeriparban

\begin{tabular}{|c|c|c|c|}
\hline & Tünetek & Előidéző okok & Megoldási lehetőségek \\
\hline 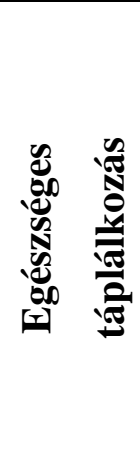 & $\begin{array}{c}\text { Káros elhízás } \\
\text { Rákos } \\
\text { megbetegedések } \\
\text { Szívbetegségek } \\
\text { Élelmiszer allergiák } \\
\text { Cukorbetegség }\end{array}$ & $\begin{array}{l}\text { “supersizing” (túlméretezés) } \\
\text { Előre feldolgozott, kész } \\
\text { ételek } \\
\text { Reklámozás gyerekeknek } \\
\text { Só, cukor és zsírtartalom } \\
\text { Adalékanyagok }\end{array}$ & $\begin{array}{l}\text { Természetes és organikus } \\
\text { termékek } \\
\text { Állami szabályozás (adók } \\
\text { stb.) } \\
\text { Egészségesebb iskolai } \\
\text { étkeztetés } \\
\text { Reklámszabályozás } \\
\text { Élelmiszercímkézés } \\
\text { Egészséges élelmiszerek }\end{array}$ \\
\hline 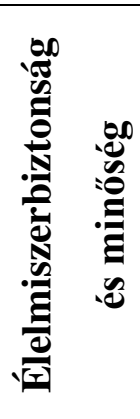 & $\begin{array}{c}\text { Ételmérgezés } \\
\text { járványok } \\
\text { Születési } \\
\text { rendellenességek } \\
\text { Rákos } \\
\text { megbetegedések }\end{array}$ & $\begin{array}{l}\text { Rovarirtó szerek } \\
\text { Műtrágyák } \\
\text { Csomagolóanyagok (BPA } \\
\text { stb.) } \\
\text { GMO élelem } \\
\text { Étel-szennyeződés }\end{array}$ & $\begin{array}{l}\text { Élelmiszercímkézés } \\
\text { Társulás a beszállítókkal } \\
\text { Új bio-anyagok }\end{array}$ \\
\hline 焉 & $\begin{array}{l}\text { Termőföld hiány } \\
\text { Élelmiszerhiány } \\
\text { Emelkedő árak } \\
\text { Hulladék }\end{array}$ & $\begin{array}{l}\text { Klímaváltozás } \\
\text { Nem-fenntartható } \\
\text { mezőgazdasági termelési } \\
\text { szokások } \\
\text { Bio-üzemanyag gyártás } \\
\text { Népesség robbanás } \\
\text { Fogyasztói szokások }\end{array}$ & $\begin{array}{l}\text { Öko-címke } \\
\text { Hatékonyabb termelési } \\
\text { technológiák } \\
\text { Helyi termékek } \\
\text { "Fair trade" (méltányos } \\
\text { kereskedelem) } \\
\text { Megújuló energia }\end{array}$ \\
\hline
\end{tabular}

Forrás: Saját szerkesztés 
Az európai polgárok a genetikailag-módosított (GMO) termények használatát, a hétköznapi termékekben jelenlévő különböző vegyi anyagokat, a mezőgazdaság környezetszennyezését, a természetes erőforrások kimerülését, a globális felmelegedést/klímaváltozást illetve a fogyasztási szokásokat mind az első tizenöt legfontosabb környezetvédelmi probléma között sorolták fel (EUROBAROMETER, 2005, 2008, 2011).

\subsubsection{Egészséges táplálkozás}

Fogyasztók, sajtó és a kormányok fokozottan kezdenek felfigyelni az egészséges életmód fontosságára és az élelmiszeripar ebben betöltött szerepére. Az Európai Közösség becslése szerint a túlzott elhízás jelenleg az egészségügyi kiadások 7\%-áért felelös, és ez az arány emelkedni fog (EUROPEAN COMMISSION, 2006). A kormányok az egészségügyi szervezetek növekvő nyomásának hatására kénytelenek ezt a számot csökkenteni és cserébe az élelmiszeripartól is elvárják, hogy alkalmazkodjon ezekhez az új követelményekhez. Az iparágat gyakran meggyanúsították felelőtlen marketing taktikákkal, mint pl. a túlméretezés gyakorlata (u.n. "supersizing”) vagy az egészségtelen termékek gyerekekre irányuló népszerüsítése. Számos kormány, köztük hazánk is, kezdeményezte egészségesebb iskolai étkeztetési programok beindítását vagy az egészségre ártalmas termékeket (“junk food”) árusító iskolai automaták betiltását. Több országban a gyerekekre irányuló promóciókat is szabályozni akarják.

Ahogy az olcsóbb, előre feldolgozott készételek egyre elterjedtebbek lesznek az egészségesebb gyümölcs- és zöldségfogyasztás kárára, úgy növekszik a rákos és szív- és érrendszeri megbetegedések száma. A fogyasztók ma már a zöldség és gyümölcs fogyasztásának jelentősége után, az előre feldolgozott élelmiszerek bevitelének alacsony mértékét tarják az egészséges táplálkozás legfontosabb elemének (MINTEL, 2009). Az élelmiszergyártó vállalatok így rákényszerülnek, hogy $\mathrm{K}+\mathrm{F}$ kiadásaik egyre nagyobb részét fordítsák egészségesebb alternatívák kifejlesztésére, hogy ez által megtarthassák és kibővíthessék vevői körüket. A természetes és organikus termékek növelik az eladási volument és prémium árakat hoznak, ugyanakkor sokszor kiteszik a nagyvállalatokat bírósági pereknek hamis reklámozás miatt.

\subsection{2 Élelmiszerbiztonság és minőség}

$\mathrm{Az}$ élelmiszertermelő vállalatok nagymértékben függnek a fogyasztói hüségtől. A fogyasztói hüség pedig a vásárlóknak az általuk választott termékek minőségébe és biztonságába 
vetett bizalmától függ. A biztonságos élelmiszertermeléssel kapcsolatos félelmeket felerősítették az elmúlt időszak sorozatos élelmiszerbiztonsági botrányai (2011-ben a német E. coli és az amerikai liszteriozis, 2008-ban a kínai tej és az Egyesült Államok-beli szalmonellózis, 2003-ban a madár influenza és a 80-as években BSE félelmek). Fertőzött élelmiszerek előállítása és forgalmazása, ami ezrek megbetegedéséhez és akár halálához is vezethet, rendkívül költséges lehet a vállalatok számára nem csak közvetlenül a bevétel csökkenés és a jogi költségek révén, de közvetetten a jó hírnév elvesztésén keresztül is.

Kutatók egyre gyakrabban okolják a rovarírtószerekben, illetve csomagoló- és fözésre használt anyagokban alkalmazott különböző vegyszereket emberi egészségre káros hatásukért (ld. Bisphenol-A, teflon). Ennek eredményeként 2010-ben az amerikai fogyasztók 39\%-a az élelmiszerekben található vegyszereket nevezte meg, mint a második legfontosabb biztonsági problémát (az előző évben ezt csak 9\% volt) a baktériáktól való félelem után, amit 44-\% említett (IFIC, 2010). Az európai fogyasztók hasonlóképpen vélekednek, itt 34\% nevezte meg az élelmiszer előállítás során használt vegyszerek egészségre káros hatását mint a negyedik legfontosabb problémát (EUROBAROMETER, 2011). Az európai fogyasztók 20\%-a a génmódosított élelmiszerek használatát sem támogatja, részben mivel ezek hatása az emberi

szervezetre még nem teljesen ismert és részben természetvédelmi okokból (EUROBAROMETER, 2011). Érdekesség, hogy pont ebben a két kérdéskörben (vegyszerek és GMO) érzik magukat a legkevésbé jól informáltnak a megkérdezett európaiak.

A szabályozó hatóságok folyamatos erőfeszítéseket tesznek annak érdekében, hogy a fogyasztók felé jobban átlátható, és értelmezhető kommunikációt tudjanak nyújtani. Ennek érdekében az élelmiszer csomagolás és címkézés területén is számos új előírást kezdeményeznek. A termék eleji (front-of-product) címkézés egyszerre számos problémát céloz meg többek közt az egészségügy, táplálkozás és környezetvédelem területén.

\subsubsection{Fenntarthatóság}

Az élelmiszeripar különösen függ a természeti erőforrásoktól. A nem fenntartható mezőgazdasági gyakorlat, a klímaváltozás és az erdőirtás következményeként a termékeny talajés megbízható vízellátás egyre szükösebb. A bio-üzemanyagok iránti kereslet növekedése erőforrásokat von el az élelmiszer növények termesztéstől. Ennek következtében drasztikusan emelkedtek az élelmiszerárak, melyek a föld lakosságának szegényebb rétegeit érintik a 
legérzékenyebben. Az élelmiszeripar nyomás alatt áll, hogy a már megmüvelés alatt álló területek kihasználtságát növelje anélkül, hogy ennek további káros hatása lenne a környezetre. Az étrend megváltozása, a jövedelmek növekedésének hatására, várhatóan megduplázza a hús iránti keresletet a fejlődő piacokon, mint például Kínában, Indiában és Brazíliában. Ez a megnövekedett húsfogyasztás tovább korlátozza a termőföld növénytermesztésre hasznosítható részét az állattartás javára.

A világ friss víz felhasználásának 70\%-a mezőgazdasági tevékenységre fordítódik. A hús iránti kereslet már így is nagy terheket ró a vízellátásra, mivel egy kilogramm marhahús előállításához kb. 15000 liter víz szükséges, míg egy kilogramm búzáéhoz csak 1500 liter (ICID, 2005). Újabb súlyos fenyegetést jelent az élelmiszer-ágazat számára a klímaváltozás, mely a növekedő hőmérséklettel, drasztikus csapadékingadozásokkal és a szélsőséges időjárás mind gyakoribbá válásával kiszámíthatatlan következményekkel jár.

Attól függetlenül, hogy a klímaváltozásról, a globális elhízási tendenciákról, a só és transzzsírsavak csökkentésére irányuló kezdeményezésekről, a front-of-product fogyasztói címkék tökéletesítéséről, vagy a gyerekeknek szánt reklámok felülvizsgálatáról beszélünk, egy biztos; a nemzetközi élelmiszer- és italgyártó cégeknek egyre nagyobb mértékben kell a külső érdekelt felek (stakeholders) kívánalmaira reagálniuk.

\subsection{A nemzetközi élelmiszeripar környezeti teljesítménye}

Az Európai Bizottság által nemrégiben kezdeményezett tanulmány szerint az Európai a legnagyobb környezeti hatást kiváltó szektorok az élelmiszer és italfogyasztás, a közlekedés illetve a lakásépítés (ETC/SCP 2011) (9. ábra). Ezen belül, az élelmiszer szektor a globális erőforrások felhasználásának 23\%-áért, az üvegház gázok kibocsátásának 18\%-áért, és a savas kibocsátások 31\%-áért felelős, legnagyobb részben a mezőgazdaság révén (ETC/SCP 2009) (3. táblázat). 


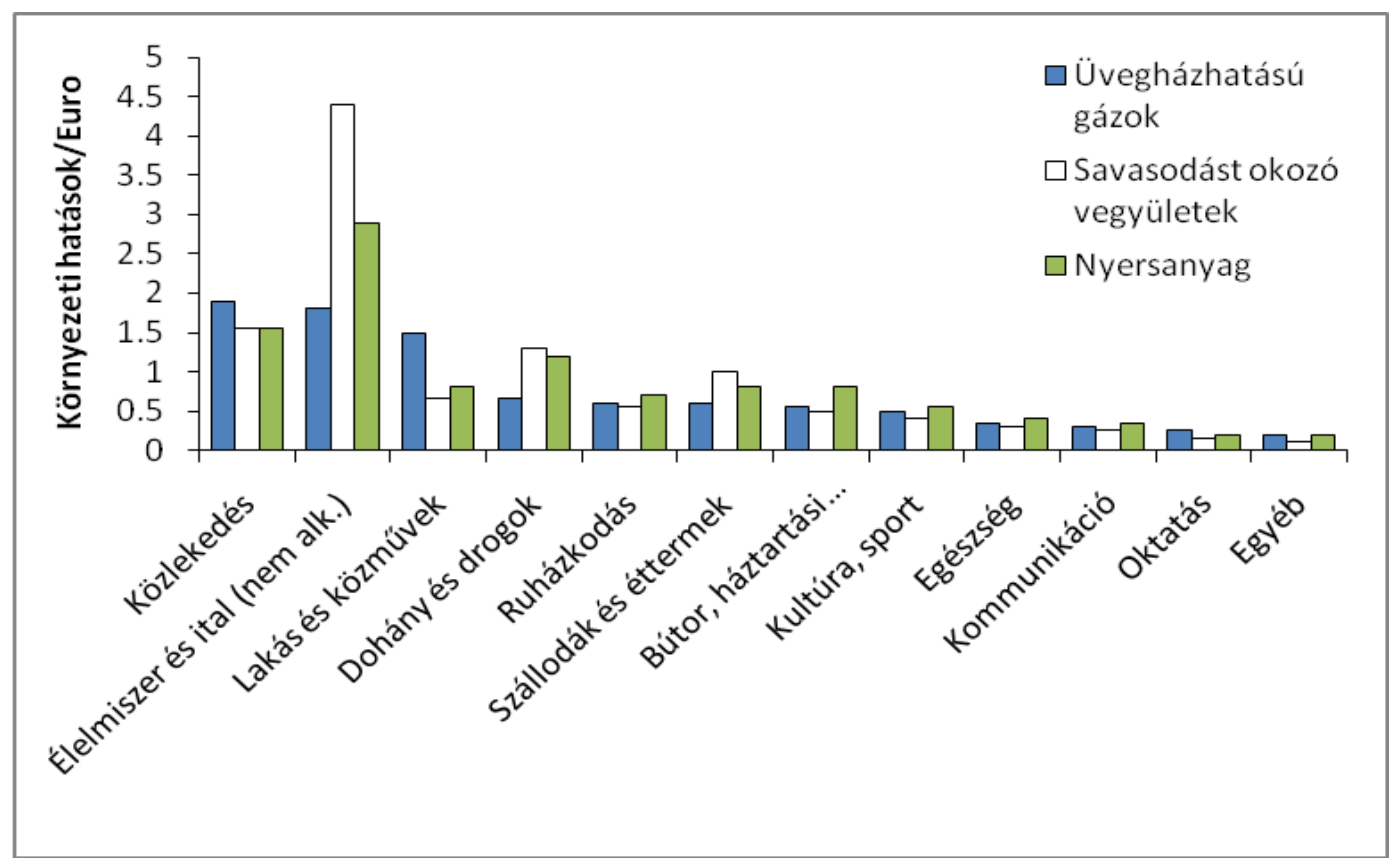

9. ábra Egy eurónyi háztartási kiadásra eső kategóriánkénti környezeti hatások az Európai Unióban Forrás: ETC/SCP Working Paper, 2011

3. táblázat Az étkezésnek és italfogyasztásnak tulajdonítható szennyezőanyag kibocsátások

\begin{tabular}{|c|c|c|c|c|c|c|}
\hline \multirow[t]{2}{*}{ Ágazat } & \multicolumn{2}{|c|}{ üvegházhatású gázok } & \multicolumn{2}{|c|}{$\begin{array}{c}\text { Savasodást okozó } \\
\text { vegyületek }\end{array}$} & \multicolumn{2}{|c|}{$\begin{array}{l}\text { Nyersanyag- } \\
\text { felhasználás }\end{array}$} \\
\hline & $\begin{array}{c}\mathrm{CO}_{2} \\
\text { ekvivalens } \\
\text { tonna/fó }\end{array}$ & $\begin{array}{c}\text { Össz- } \\
\text { fogyasztás } \\
\%\end{array}$ & $\begin{array}{c}\mathrm{SO}_{2} \\
\text { ekvivalens } \\
\mathrm{kg} / \text { fö }\end{array}$ & $\begin{array}{c}\text { Össz- } \\
\text { fogyasztás } \\
\%\end{array}$ & tonna/fó & $\begin{array}{c}\text { Össz- } \\
\text { fogyasztás } \\
\%\end{array}$ \\
\hline $\begin{array}{c}\text { Mezőgazdaság, } \\
\text { erdőgazdálkodás, } \\
\text { halászat }\end{array}$ & 0.42 & 3.8 & 5.10 & 8.5 & 1.10 & 6.9 \\
\hline $\begin{array}{l}\text { Élelmiszerek, } \\
\text { dohány és italáruk }\end{array}$ & 1.00 & 8.8 & 9.70 & 16.2 & 2.00 & 12.3 \\
\hline $\begin{array}{l}\text { Elektromos aram, } \\
\text { kőolaj, meleg víz és } \\
\text { göz }(20 \%)\end{array}$ & 0.30 & 2.7 & 1.60 & 2.6 & 0.20 & 1.1 \\
\hline $\begin{array}{c}\text { Kis- és } \\
\text { nagykereskedelem } \\
(20 \%)\end{array}$ & 0.10 & 1.2 & 0.70 & 1.2 & 0.10 & 0.9 \\
\hline $\begin{array}{l}\text { Hotelek és éttermek } \\
\qquad(50 \%)\end{array}$ & 0.20 & 1.8 & 1.70 & 2.8 & 0.30 & 1.9 \\
\hline $\begin{array}{l}\text { Összes étkezésnek } \\
\text { és italfogyasztásnak } \\
\text { tulajdonítható } \\
\text { kibocsátás }\end{array}$ & 2.0 & 18.0 & 18.8 & 31.0 & 3.8 & 23.0 \\
\hline
\end{tabular}

Forrás: ETC/SCP Working Paper 2009 
Az adatok az összes az élelmiszeripari termék elóállitásakor keletkezett kibocsátást magukba foglalják, a termőföldektől a szupermarketek polcaiig, beleértve a mütrágyagyártást, üzemanyag előállítást és felhasználást, a termelésben felhasznált elektromos áramot stb. Az élelmiszer- és italáruk tényleges megtermelése a legfőbb okozója az étkezésből és italfogyasztásból származó negatív környezeti behatásoknak (az üvegházhatású gázok esetében például a teljes életciklusból származó kibocsátások 70\%-áért felelős). A marhatenyésztés és tejgazdálkodás a legnagyobb kibocsátóként világszerte különösen rossz hírnévnek örvend.

Az ENSZ hasonló statisztikákat publikált. A 2005-ös globális emisszióból a mezőgazdaság a széndioxid 10-12\%-ával, a dinitrogén oxid 60\%-ával és a metán kibocsátás mintegy felével részesedett (az elektromos áram és üzemanyag felhasználást figyelmen kívül hagyva). Globálisan, a mezőgazdaság $\mathrm{CH}_{4}$ és $\mathrm{N}_{2} \mathrm{O}$ kibocsátása majdnem 17\%-kal növekedett 1990 és 2005 között (IPPC, 2007). Az Environment America nonprofit szervezet 2010 novemberében publikált kutatása szerint a legnagyobb agrárvállalatok felelősek az Egyesült Államok folyóinak mintegy 160000 kilométer hosszú szakaszának valamint belső tavai 650000 hektárnyi részének teljes lepusztulásáért (EAP, 2010). Az Európai Unión belül a csomagolóanyagokból származó hulladék több mint 160 kg személyenként. E hulladék majdnem kétharmada az élelmiszerfogyasztásból származik (INCPEN, 2001).

Vitathatatlan ugyanakkor, hogy pontosan ezek a nagy nemzetközi vállalatok rendelkeznek olyan hatalmas erőforrások fölött, melyeket egy sokkal hatékonyabb és fenntarthatóbb élelmiszertermelés kifejlesztésére fordíthatnának. A Föld száz legnagyobb gazdaságából ma már csak 49-et képvisel ténylegesen egy ország, a többi 51 pedig multinacionális nagyvállalat (ANDERSON \& CAVANAGH, 2000).

Nemzetközi felmérésekben (ld. CERES, Newsweek vagy CDP) a tradicionálisan szennyezö iparágak, mint az olaj- és gázipar vagy a vegyipar jobban teljesítettek, mint az élelmiszeripar, annak köszönhetően, hogy ezek az iparágak kerültek legelőször a társadalmi figyelem középpontjába, így már nagyobb gyakorlatot fejleszthettek ki a jelentéstételben és elszámoltathatóságban. Megvizsgálva környezeti teljesítményüket, az élelmiszeripart képviselő vállalatok számos tanulmányban a ranglétra alsó részén végeztek. (4. táblázat). 
4. táblázat Környezeti teljesítmény iparágak szerinti besorolása

\begin{tabular}{lc}
\hline Iparág & $\begin{array}{c}\text { Átlagos } \\
\text { pontszám (100) }\end{array}$ \\
\hline Panel A & 51.9 \\
Vegyipar & 48.8 \\
Elektromos áram & 47.9 \\
Jármüvek & 42.5 \\
Ipari gépek és berendezések & 42.2 \\
Fémalapanyag és fémfeldolgozás & 37.2 \\
Faipar & 34.8 \\
Olaj és gázkitermelés, finomítás & 21.4 \\
Szénkitermelés & 17.6 \\
Élelmiszer, ital és dohánytermékek & 16.6 \\
Légitársaságok & \\
Forrás:Report on Corporate Governance and Climate Change, CERES, 2006 & \\
\hline \hline
\end{tabular}

\section{Panel B}

Technológia

79.3

Gyógyszergyártás

78.1

Bankok, biztosítás, pénzügy

72.8

Kiskereskedelem (kivéve élelmiszer)

72.1

Tartós fogyasztási cikkek, gépkocsik

71.6

Légitársaságok és logisztika

71.3

Nem specializált ipari gyártás

71.1

Ipari áruk

69.1

Olaj és gázkitermelés, finomítás

68.4

Egészségügy

67.7

Alapvető alapanyagok

Élelmiszer, ital és dohánytermékek

62.1

Közművek

60.1

Forrás: Newsweek Green Rankings, 2010 
Az utóbbi időszakban azonban, a különböző élelmiszerbiztonsági problémák, bioüzemanyagok fellendülése és ezzel kapcsolatos élelmiszerhiányok és áremelkedések, valamint a fenntartható fejlődés kapcsán előtérbe kerültek az élelmiszeripari vállalatok is. Így remélhetőleg mind nagyobb hangsúly helyeződik majd ezen iparág CSR, és ezen belül, környezeti teljesítményére is. A ,stakeholder” elmélet alapján elvárható, hogy a különböző érdekelt felek a vállalatokat környezeti teljesítményük javítására kényszerítik. Ha az információ alapú szabályozás müködik, akkor a környezetvédelemmel kapcsolatos hírek hatását, legyen az pozitív vagy negatív, a vállalatok tőzsdei árában is nyomon követhetjük.

\subsection{A környezeti és pénzügyi teljesítmény mérése}

\subsubsection{Pénzügyi teljesítmény}

A legegyszerübb és egyben legdirektebb értékelés a vállalat pénzügyi teljesítményének mérésére a vállalat tőzsdei ára. Az adatok könnyen hozzáférhetőek, hosszú távon elérhetőek és egyben egymással összehasonlíthatóak is. Hátránya, hogy csak a tőzsdén jegyzett vállalatok értékelésére használható. Előnye viszont, hogy a vállalattal szembeni jövőbeli elvárásokat is tükrözi.

A számviteli alapú értékbecslés több kihívást tartalmaz, mivel az ehhez szükséges adatok beszerzése időigényesebb. Figyelembe kell venni az esetenként eltérő számviteli szabályokat is. Előnye, hogy a mutatók számítási módja standardizált, hátránya, hogy a pénzügyi mutatók múltorientáltak. Többféle pénzügyi mutató is létezik, mint az eszközarányos nyereség (Return on Assets, ROA), a saját tőke-arányos nyereség (Return on Equity, ROE), az árfolyam-nyereség arány (Price/Earning Ratio, P/E), vagy Tobin’s Q (a vállalat piaci értékének és az eszközök újrabeszerzési értékének hányadosa).

\subsubsection{Környezeti teljesítmény}

A környezeti teljesítmény mérésének egyik fó problémája, hogy rendkívül sok megközelítési lehetősége van. További problémát okoz, hogy egyes összetevői nehezen 
kimutathatók illetve számszerüsíthetők. Hogy a kutatók mely mutatókat választják, vagy tartják fontosnak sokszor szubjektív döntésen illetve az adatok elérhetőségén alapul. A környezeti teljesítményt általában két oldalról szokták megközelíteni: a vállalat tevékenysége révén a környezetben bekövetkezett változások mérése (üvegházhatású gázok, anyagfelhasználás, hulladék kibocsátás, kirótt büntetések stb.) illetve a környezetmenedzsment intézkedések jelenléte (minőségi bizonyítványok, környezetirányítási rendszerek, vállalati jelentések, auditok stb.). Elörelépést jelent, hogy egyre többen hangsúlyozzák a preventatív illetve az elöírásokon felüli intézkedések fontosságát. Az elmúlt tíz év fejleménye a közhasznú szervezetek által kezdeményezett és később a befektetői alapok által támogatott és továbbfejlesztett mindenre kiterjedő vállalatelemzés, mely a vállalatokat hasonló dimenziók mentén értékeli és rangsorolja. Ezen rangsorolásoknak kettős előnye, hogy a nyilvánosság bevonásával a rosszul teljesítő vállalatokat cselekvésre ösztönzi, illetve a befektetői alapok révén pénzügyi kihatásuk is van.

\subsection{A környezeti és pénzügyi teljesítmény közötti összefüggés}

Azok a vizsgálatok, amelyek párhuzamot próbáltak vonni a vállalati társadalmi felelősség, egy nem pénzügyi teljesítmény, és a vállalatok pénzügyi teljesítménye között, ellentmondó eredményekre vezettek. A nemzetközi irodalom áttekintéséből kitünik, hogy a vállalatok környezeti, társadalmi és igazgatási politikája, valamint a pénzügyi teljesítménye közti kapcsolatot széles skálán vizsgálták a negatívtól a nem létező kapcsolaton át a teljesen pozitív korrelációig (átfogó betekintéshez ld. MARGOLIS \& WALSH, 2003, illetve ORLITZKY, SCHMIDT \& RYNES, 2003).

A három leggyakrabban alkalmazott módszer a pénzügyi és a nem-pénzügyi eredmények közti korreláció vizsgálatára az esettanulmány, a számviteli alapú cégértékelés és a portfolióelemzés. Ezek lényege röviden:

- a rövid távú esettanulmány módszere a piac reakcióit követi nyomon a negatív (olajszennyeződés) vagy pozitív (környezeti díj) hírekre;

- a hosszabb távú (mikro-) gazdasági megközelítés a vállalatok pénzügyi és környezeti teljesítményét hosszabb időszakban vizsgálja, amikor is a fenntartható vezetési politika kialakítására fordított tőke megtérülését számviteli alapon vizsgálják; 
- a portfolió elemzés során két eltérő összetételủ vállalati portfolió pénzügyi teljesítményét (könyvviteli vagy piaci alapon) hasonlítják össze a környezeti teljesítménnyel.

A továbbiakban röviden ismertetem ezen módszerek előnyeit és hiányosságaikat. A disszertációmban alkalmazott esettanulmány módszer statisztikai hátterére, illetve a tanulmányok eddigi eredményeire részletesen a 2.10 és 2.11 . fejezetben térek ki.

\subsubsection{Az esettanulmány módszere}

A módszer története hosszú időre tekint vissza BALL\&BROWN (1968) és FAMA et al. (1969) elsőként ismertté vált módszertani munkái óta, és azt folyamatosan továbbfejlesztették (BROWN\&WARNER 1980, 1985; DYCKMAN, PHILBRICK\&STEPHAN 1984, MORSE 1984, SCHIPPER\&SMITH 1986, FAMA\&FRENCH 1992, újabban CAMPBELL, LO\& MACKINLAY (1997). Az eljárást alkalmazták számos különböző esemény tőzsdei hatásának értékelésére, mint a fúziók, hozamok és osztalékok bejelentése, vagy könyvviteli gyakorlat változása. A módszert később a tőzsde környezeti hírekre adott reakcióinak elemzésére is adaptálták (HAMILTON 1995; KONAR et al. 1997; DASGUPTA et al. 1998). KOTHARI és WARNER (2004) több mint 500 esettanulmányt ismertet, amelyeket 1974 és 2000 között publikáltak a jelentősebb tudományos folyóiratokban.

Az esettanulmány módszer alapja az, hogy a tőkepiac hatékony és csaknem azonnal befogadja az új információ (hírek) hatását a cégek jövőben várt profitjairól. A hatékony piac hipotézise (FAMA, FISHER, JENSEN, \& ROLL, 1969) szerint egy jól teljesítő tőkepiacon a részvényárak szolgáltatják a rendelkezésre álló legjobb és pártatlan becslést egy cég vagyonának várható értékéről. Az esettanulmány hatékony módszer, amellyel, a specifikus eseményekkel összefüggő piaci hozamokat becsülni lehet, míg egyidejüleg az általános részvény árakat befolyásoló piaci tényezőket ellenőrzésünk alatt tarthatjuk. Ez idáig az esettanulmányok nyújtják a legjobb bizonyítékot a környezeti és tőzsdei teljesítmény közti korrelációra. Az esettanulmányok ezen túl fontos szerepet játszanak a tőkepiaci kutatásban, mint a piaci hatékonyság vizsgálatának elsődleges eszközei.

Az esettanulmányok irodalmában két általános ökonometriai megközelítés szerepel(részletesebben lásd 2.10. Az eseménytanulmány ökonometriai módszerei). Az egyik, amit hagyományos vagy standard esettanulmánynak is neveznek, az abnormális hozamokat a 
tényleges és megjósolt hozamok különbségéből számítja ki, ahol a megjósolt hozamot valamely benchmark modell, mint a piaci modell (market model) vagy a tőkepiaci árfolyamok modellje (Capital Asset Pricing Model, CAPM) becsült maradékából. A másik módszer, amely regresszió alapú esettanulmányként is ismert, névleges (dummy) változókat használ, amelyek illeszkednek az esemény időszakához egy regressziós szerkezetben, ami meghatározza az esemény hatásait. Az abnormális hozamokat a regressziós egyenlet koefficienseivel modellezik. Mindkét módszer be tud fogadni további piaci változókat, hogy értelmezze a hatását olyan jellemzőknek, mint a cég mérete vagy kockázati szintje.

Az esettanulmányi eljárás népszerüsége ellenére az empirikus kutatás nem hozott következetes vagy összehasonlítható eredményeket, mivel a kutatók nagyon különböző magyarázatokra jutottak a kapott eredményekböl. FAMA (1991) is elismerte, hogy az esettanulmány technikája számos módszerbeli hibát rejt magában. A technikai nézeteltérések mellett néhány alapvető elméleti kérdés is vitatható:

a) Ha a piac valóban hatékony, akkor minden információ már beépül az árba és így csak a jóhír elvesztéséből származó büntetés maradhat. Ez különösen igaz az új könyvelési szabályok bevezetése óta (az amerikai általánosan elfogadott számviteli alapelvek (Generally Accepted Accounting Principles, US GAAP) szerint múködő vállalatoknál a FIN47 szabály 2005-ös kötelező bevezetése, illetve a nemzetközi pénzügyi beszámolási standard (International Financial Reporting Standards, IFRS) hasonló rendelkezései). Ezek a szabályok előírják, hogy a cégek az összes környezeti kinnlevőségeiknek valós értékét belefoglalják könyvelésükbe. A 2002-es Sarbanes-Oxley törvény- amely ugyan csak az amerikai tőzsdén jegyzett cégek számára kötelező érvényü, de számos privát illetve nem amerikai érdekeltségű cég is alkalmazza- még ennél is szigorúbb, nem csak számviteli beszámolási kötelezettséget ír elő.

b) Az esettanulmány rövid időtartamú. A kezdeti reakciók után a piac visszatér az eredeti irányba és ha a piac hatékony, úgy ez csaknem azonnal végbemegy (10. ábra). Az esettanulmány nem tudja elemezni a hosszú távú irányzatokat és nem tudja befogadni a cég környezeti teljesítményének javítására tett objektív intézkedéseit sem, ha azok nem kötődnek egy adott dátumhoz. Hogy dönthető el, hogy van-e hosszú távú hatás (pl. a jobb környezeti teljesítményt nyújtó vállalatok hosszú távon felül múlják-e iparágbeli társaik eredményeit?) 


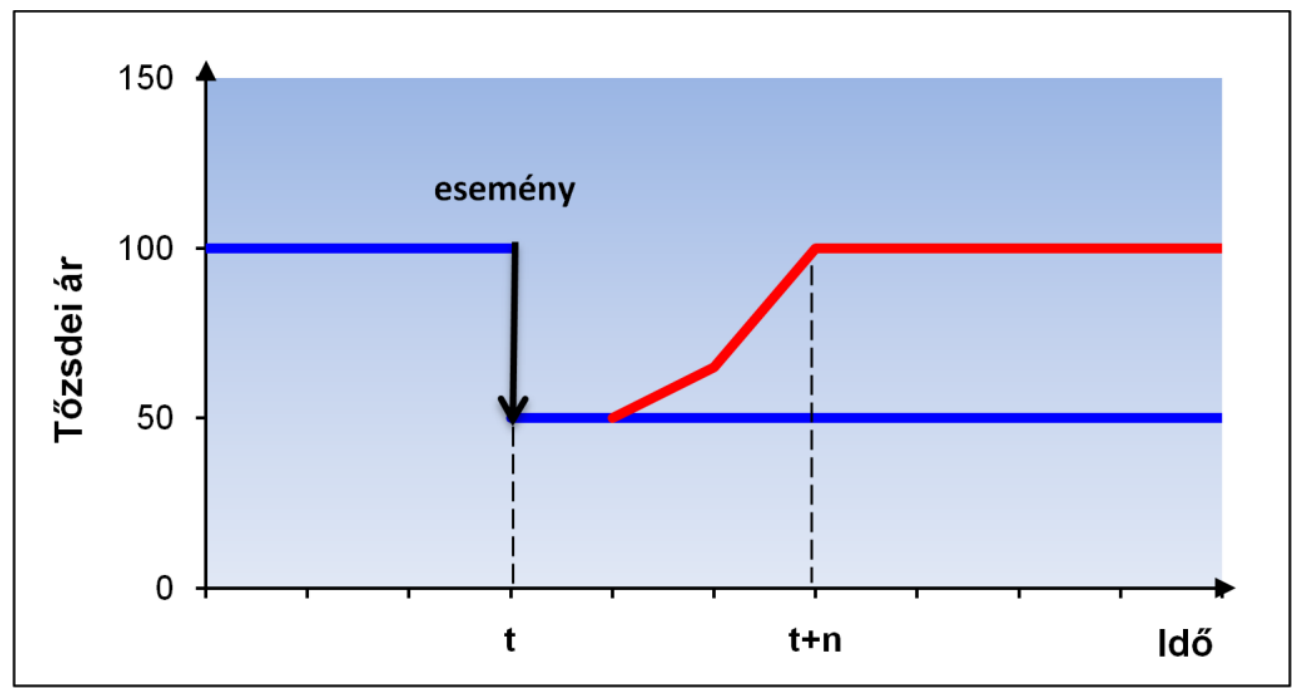

10. ábra Piaci reakció előre nem látott negatív eseményre

Forrás: Saját szerkesztés

c) Az esettanulmányok egyik legnagyobb gyengesége, hogy a nem várt eseményektől függ. Ha az esemény előre látható, akkor annak hatása már az eset időpontja előtt beépül a részvények áraiba.

\subsubsection{Az értékbecslési model}

Ez a megközelítés a könyvvitelre alapozott értékelési model különböző verzióit alkalmazza, ahol egy cég piaci értéke megfelel a könyvelési értéknek és más nem számviteli alapú érték-releváns információnak (mint pl. a környezeti teljesítmény). Ez a módszer, amely a hosszú távú viszonyok felderítésére törekszik, vizsgálja a kapcsolatot pl. a környezet szennyeződés közlése (mint a mérgező hulladék telephelyek (Superfund) utáni kötelezettségek vagy mérgező anyag kibocsátási lista (TRI)) és számos könyvelési teljesítmény jelző között, mint amilyenek a Tobin’s Q, eszközarányos nyereség, árbevétel arányos nyereség, vagy saját tőke-arányos nyereség.

DOWELL, HART és YEUNG (2000) az elsők közt elemzik ezt a témát. Tanulmányukban a szerint csoportosították az amerikai vállalatokat, hogy azok világszerte alkalmazzák-e az U.S. környezeti szabványait, vagy alacsonyabb standardokat érvényesítenek az Egyesült Államokon kívül, ahol azt megengedik. Pozitív korrelációt találtak a vállalat 
tőzsdepiaci értékének a tényleges vagyoni értékhez viszonyított aránya (Tobin’s Q) és a cég környezeti teljesítménye között.

Egy cég értéke felosztható a tényleges és az eszmei vagyonra. A tényleges értéket általában úgy definiálják, mint azokat a vagyontárgyakat, amelyek valamilyen fizikai formában léteznek, mint a tulajdon, üzem és berendezések, készpénz, árukészlet, stb. Az eszmei értéket azok a termelési tényezők képviselik, amelyek közremüködnek a cég bevételi képességében a tényleges vagyon hozamán felül. Ilyenek a szabadalmak, védjegyek, tulajdonjogi ismeretek, márkanevek és a cég üzleti hírneve. Az eszmei vagyon, azonban, jelentheti a cég kötelezettségeit is, ami csökkenti a profitabilitást. Erre példa lehet a fogyasztók bizalmának elvesztése tisztességtelen tevékenységet követően, a termék visszahívás vagy környezeti károkból származó várható kötelezettségek.

A cégértékelés megkívánja, hogy a kutató ne csak a cégvagyon összetevőire fókuszáljon (pl. tényleges és eszmei értékek), hanem a pénzügyi teljesítmény számos más változójának hatására is, mint a cég piaci részesedése, az ipar koncentrációja, az árbevétel növekedése, hirdetési vagy kutatás-fejlesztési kiadások, a cég nagysága, kockázati szintje, az import mértéke azon a piacon, amelyre a cég termel.

A cégértékelési módszer problémái az alábbiak:

a) Ez az értékelés erősen nyugszik a nyilvánosan hozzáférhető könyvelési adatokon. Amint az utóbbi időkben láthattuk, ez nem mindig a legjobb minőségü. Még a Sarbanes-Oxley törvény elfogadása és annak oldalága a FIN 47 szabály után is különbségek vannak a könyvelési standardokban, és az igazgatóság határozottan elfogult, amikor környezeti kötelezettségek jönnek szóba.

b) A módszer támogatói úgy vélik, hogy a pozitív környezeti teljesítmény a jó hírnév növelését és a beruházók bizalmának erősödését eredményezi. Azok a cégek, melyek a környezetvédelemben elöl járnak, így kevésbé kockázatosnak tünnek, és így kisebb költséggel juthatnak tőkéhez. A standard eszközárazási elmélet (asset-pricing theory) szerint a kisebb kockázat alacsonyabb várt hozammal járna. Azonban, mint láttuk, számos vizsgálat abnormális pozitív hozamot mutatott ki környezetvédelemben élenjáró cégeknél. Ezt a tanúságot nehéz összeegyeztetni a kockázat-hozam paradigmával, kivéve, természetesen, ha a piac nem értékeli hatékonyan a CSR összetevőit. 
c) További negatívum, hogy ez a fajta értékelés a múltban elért pénzügyi mutatókra épül, és nem veszi figyelembe a cég jövőbeli, várt pénzügyi teljesítményét.

\subsubsection{A portfolió analízis}

A portfolió analízisnél két vagy több, egymást kölcsönösen kizáró, látszólagos vagy valós portfolió kockázattal helyesbített átlagos hozamát hasonlítják össze. A portfoliókat egy vagy több, kiválasztott kritériumra építik (pl. nem alkalmaznak gyerekmunkát, vagy támogatják a helyi termelőket, stb.). A portfoliót ezután egy olyan teljesítményorientált modellel elemzik, amely a szokásos befolyásoló tényezőket kontroll alatt tartja. Az elemzést végezhetik egy iparágilag kiegyensúlyozott portfolión (industry balanced portfolios) vagy több iparágazat hasonlítható össze egymással illetve az átfogó piaci irányzatokkal. A portfoliókat gyakran úgy alakítják ki, hogy azokba a vállalatokba fektetnek be, amelyek környezeti vezetők a maguk sajátos iparágában. Ez lehetővé teszi a befektetést az olaj- vagy vegyipari vállalatokba illetve más erősen szennyező iparágakba is, mivel ilyenkor a vállalat teljesítményét a hozzá hasonlókéval vetik össze és nem egy ideális standarddal.

COHEN et al. (1997) kutatásai arra utalnak, hogy a befektetőknek sem haszna sem kára nem származik abból, ha környezeti teljesítményben élenjáró vállalatokat előnybe részesítik. Későbbi vizsgálatok tanúsága szerint azonban a jutalék tekintélyes lehet, ha a befektetésnél a környezeti vagy más társadalmi tényezőket figyelembe veszik (DERWALL et al. 2004; KEMPF \& OSTHO 2007). A részvények hozamainak fó eszközárazási modelljei a piaci modellre alapozott egyfaktoros modell (SHARPE, 1963) és a tőkepiaci árfolyamok modellje (Capital Asset Pricing Model, CAPM) (SHARPE 1964, LINTNER 1965). Mivel a CAPM számos hiányossággal jár, FAMA és FRENCH (1963) kidolgoztak egy háromfaktoros modellt, amely a piaci többlethozamon kívül a méretre és értékre vonatkozó további tényezőket is figyelembe vesz. Fama és French észlelték, hogy a részvények két fajtája hajlamos túlteljesíteni a piacon. Ezek a kisméretű (small-caps) részvények (méret tényező) és a magas részvényár/könyvszerinti érték rátájú (book-value-to-price) részvények (érték tényező). A méret negatívan viszonyul a részvényhozammal, míg a piaci és könyvszerinti érték hányadosa (Book-To-Market factor) pozitíven hat a részvényhozamra (FAMA \& FRENCH, 1992). Ugyanakkor a kutatók egy másik változót is vizsgálni kezdtek, nevezetesen a momentum tényezőt. A momentum, amely a részvények azon hajlama, hogy a már megkezdett irányba folytassák mozgásukat, alapvető 
fogalom a részvények árában tapasztalható trendek elemzéséhez. JEGADEESH és TITMAN (1993) megfigyelte, hogy az a részvény, amely jól/rosszul teljesít háromtól tizenkét hónapon át, megtartja ezt az irányt a következő ilyen szakaszban is. Erre a megfigyelésre alapozva CARHART (1997) kidolgozott egy négyfaktoros modellt, amely magába foglalja a momentum változót is. A momentum létezése anomália, amelynek elméletileg nem szabadna léteznie. A probléma az, hogy az értékpapírok árának növekedése, önmagában, nem lenne szabad, hogy további növekedést eredményezzen. A hatékony piac hipotézise szerint, növekedés csak akkor történhetne, ha változik a kereslet és a kínálat, vagy ha új információ jelentkezik. A momentum megjelenése jórészt az irracionális befektetőkre jellemző torzításnak tulajdonítható, akik alulvagy túlreagálják a vállalat specifikus információk nyilvánosságra hozását. Az ilyen fajta elemzés néhány alapvető kritikáját az alábbiakban említem. További hátrányokat a következő alfejezetben tárgyalok.

a) Az eredményeket erősen befolyásolja a választott eszközárazási modell. A gyenge környezeti teljesítmény egyszerü tőkepiaci árfolyamok modelljével kiszámított látszólag szignifikánsan negatív hatása például elhalványul, ha az értékpapír teljesítményének értelmezését a Fama-French háromfaktoros vagy a Carhart négyfaktoros modellre alapozzuk.

b) A hasonló jellemzőkre alapozva létrehozott portfolióknál a korreláció kockázata növekszik (értsd a vállalatok teljesítményükkel egymást is befolyásolhatják). Minél specifikusabb a portfolió, annál nagyobb a korreláció.

\subsubsection{A portfolió elemzés kiterjesztése}

Az utóbbi években tapasztalható az etikus befektetési alapok és portfoliók sokasodása. Következéskép, különböző vállalat rangsorolási módszerek jöttek létre, amelyek új utat nyitottak a vállalat környezeti teljesítményének mérésére. A kutatók az új módszert ötvözték a korábbiakkal a hosszú távú kitekintés reményében. A vállalatok pénzügyi értékelésére a vállalat részvény árfolyamait, vagy számviteli adatait használják, míg a környezeti teljesítményhez különböző rangsorolási és teljesítmény-mátrix rendszereket alkalmaznak, amelyeket vagy a kutatók maguk gyüjtöttek össze és hoztak létre, vagy pedig valamely professzionális CSR részvény portfolió társaság, mint a KLD, GES, ASSET4, Innovest stb., elemzői állítottak össze.

Ezek a rendszerek általában a környezetileg releváns adatokat értékelik ki és osztályozva a vállalati célkitüzéseket és eredményeket környezeti teljesítmény mátrixot hoznak létre. A 
teljesítményértékeléseket évente, néha havonta kidolgozzák és így a vállalat hosszú távú felmérésére is szolgálhatnak. Számos kutató alkalmazza ezt az új információt kutatási módszereiben: a KLD indexet (DERWALL \& VERWIJMEREN 2007, CHATTERJI et al. 2009, STATMAN \& GLUSHKOV 2009, BARON et al. 2009); az Innovest ökohatékonysági besorolását (Derwall et al. 2004, GUENSTER et al. 2006); a GES környezeti kockázat és lehetőség besorolását (OLSSON 2007, SEMENOVA \& HASSEL 2008), vagy a Newsweek zöld besorolását (ANDERSON-WEIR, 2010, LYON et al. 2011).

A vitatott kérdések itt a következők:

a) A múltbeli következetlenségek fő okai közé tartozik a környezeti teljesítmény értékelés objektív kritériumainak hiánya. Egyes kutatók a közérdekü csoportok és befektetési alapok által létrehozott vállalati besorolásokba vetik hitüket, vagy szubjektív kategóriákat állítanak fel saját adataikból, mások a büntetési károkat és a perköltségeket vizsgálják ipar szerte, ismét mások az etikus befektetési alapok piaci hozamát vetetik össze az átlag piaci indexszel.

b) A mérőszámok néha erősen szubjektívek és gyakran látszatintézkedéseket is tartalmaznak (window dressing). Így például, számos vállalatnak van CSR beszámolója. Javítja ez a tényleges környezeti teljesítményüket? Sok esetben valószínüleg nem, de a vállalatok mégis jó pontokat kapnak az intézményi befektetőktől.

c) A rangsorolási módszerek nem különböztetik meg a vállalatok által a környezeti teljesítmény javítására tett megelőző lépéseket (tanúsítványok, zöld beszerzések stb.) és a büntető vagy egyéb impakt faktorokat, amelyek az eseményt követően utólag befolyásolják a vállalat pénzügyi eredményeit (perek, büntetések).

d) Többen állítják, hogy a társadalmilag felelős befektetési alapok pénzügyi eredményei nem azért jobbak, mert a környezettudatos cégek általánosságban jobban teljesítenek, hanem mert az alapkezelők tapasztaltak és tehetségesek a részvényeket kiválasztásában. Kétségtelenül a portfolióelemzés legfőbb gyengesége, mind a létező mind a virtuális alapok esetén az, hogy csak az átlagos pénzügyi teljesítményt veszik figyelembe a portfolióba tartozó cégek részvényeinél. 


\subsection{Az eseménytanulmány ökonometriai módszerei}

A pénzügyi közgazdaságtanban a FAMA, FISHER, JENSEN, \& ROLL (1969) által kidolgozott eseménytanulmány módszer (event study) vált a tőzsdei árak valamilyen bejelentésre tett változásának elfogadott mérési eszközévé. Az eseménytanulmányokat használják a) a nullhipotézis vizsgálatára, hogy a piac az új információkat hatékonyan képes feldolgozni, illetve b) a hatékony piac hipotézise mellett az egyes eseményeknek a részvényesi vagyonra kifejtett hatásának vizsgálatára (BINDER, 1998).

Az eseménytanulmány első lépése megfelelö események kiválasztása, illetve az eseményablak meghatározása, amely az az időintervallum, amin belül a cégek piaci árát akarjuk vizsgálni. A reziduumok kiszámításához az eseményablak előtti adott hosszúságú, általában hat hónaptól egy évig terjedő, becslési szakasz adatait használják (11. ábra).

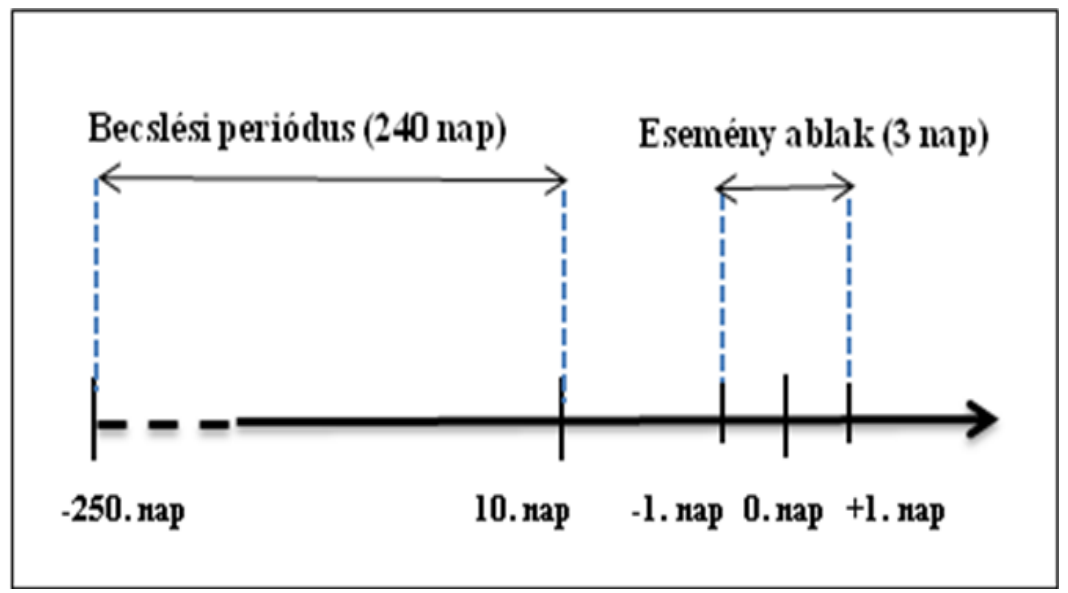

11. ábra Az eseménytanulmány idővonala

Forrás: Saját szerkesztés

Egy esemény hatásának vizsgálatához az abnormális hozamot (abnormal return, AR) kell megmérni. Az abnormális hozam a múltbeli (ex-post) események alapján várt (becsült) és a tényleges (normál) hozamok közötti különbség. Tehát $i$ cég és esemény periódus $t$ esetén a következőképpen számítandó:

$$
A R_{i t}=R_{i t}-E\left(R_{i t} \mid X_{t}\right),
$$


ahol $A R_{i t}, R_{i t}$, és $E\left(R_{i t} \mid X_{t}\right)$ az abnormális, tényleges és normális hozamok, és $X_{t}$ a szabályozó információ a normális hozam modellhez. Ennek modellezéséhez gyakran alkalmazzák az állandó átlagos hozamot, amikor $X_{t}$ állandó, és a piaci modellt, amelynél $X_{t}$ a piaci hozam. A piaci model állandó lineáris viszonyt feltételez a piaci és a tőzsdei hozam között. A piaci model definíciója:

$$
R_{i t}=\alpha_{i}+\beta_{i} R_{m t}+\varepsilon_{i t}
$$

ahol $R_{m t}$ a piaci portfolió hozama a $t$ időszakban, $\varepsilon_{i t}$ a zéró átlagos hiba tényezö, $\alpha_{\mathrm{i}}$ és $\beta_{\mathrm{i}}$ pedig a becsült paraméterek. Az általános piaci hatások kontrolljához leggyakrabban egy széles bázisú tőzsdei indexet, mint amilyen a Standard and Poor's (S\&P) 500, használják a piaci portfolió helyett. Ebben a keretben az abnormális hozamot modellezik a piaci modellből jósolt hibával:

$$
A R_{i t}=R_{i t}-\hat{\alpha}_{i}+\hat{\beta}_{i} R_{m t}
$$

Az abnormális hozam modellezésére alternatív mód a regressziós koefficiens. Ebben az esetben a számításhoz az adatok összességét használják. Ilyenkor egy dummy változót adnak a piaci modellhez, amely az $\mathrm{E}_{\mathrm{t}}$ periódust képviseli:

$$
R_{i t}=\alpha_{i}+\beta_{i} R_{m t}+\delta_{i} E_{t}+\varepsilon_{i t}
$$

Ebben a keretben a $\delta_{i}$ koefficiens az abnormális hozama a cég $i$-ik részvényének a $t$ időszakban, amit közvetlenül becsülnek a regresszióban. Ha több esemény történik, akkor külön-külön dummy változót lehet használni mindegyik időszakra. Alternatívaként egy egységnyi dummy változót lehet használni mindegyik esemény időszakára. Utóbbi esetben a dummy változó koefficiense képviseli az $i$ cég átlagos abnormális hozamát az összes esemény időszakában. Longitudinális elemzések esetében a különböző időperiódusokat is modellezhetjük dummy változókkal (DASGUPTA et al., 2005). MACKINLAY (1997) és BINDER (1998) részletesen tárgyalja az eseménytanulmány módszertanát. 
A fenti egyenlet egyszerúen becsülhető a szokásos legkisebb négyzetekkel (OLS). Ennek azonban több feltétele van. Az egyik feltétel az, hogy az $\varepsilon_{i t}$ hibatényező sorozatosan nem korrelált legyen. LO és MACKINLAY (1988) azonban kimutatta, hogy az egyedi részvények egymást követő hozamai ténylegesen korrelálnak, és a nagy hozamokat további nagy hozamok követik. Egy másik feltétel az, hogy a hibatényező normális eloszlást kövessen állandó varianciával, vagyis legyen homoszkedasztikus. GIACCOTO és ALI (1982) dokumentálta, hogyha a homoszkedaszticitás feltétele nem teljesül, a paraméter becslése eredménytelen lesz és így minden erre alapozott következtetés félrevezető lehet. Ezért ahhoz hogy egy specifikus esemény hatását a tőzsdei árakra felmérjük, számításba kell venni a variancia időbeli változását (heteroszkedaszticitás). ENGLE(1982) kidolgozott egy modellt, amelyben a tényleges feltételes variancia függvénye a négyzetes random zavarás múltbeli értékeinek, amit autoregresszív feltételes heteroszkedaszticitásnak (ARCH) nevezett. Az ARCH modellt BOLLERSLEV (1986, 1987) módosította, és megengedte, hogy a tényleges feltételes variancia függjön mind a múltbeli feltételes varianciától, mind a múltbeli négyzetes random zavarástól. Az előnye az általános autoregresszív feltételes heteroszkedasztikus $(\mathrm{GARCH})$ modellnek, hogy nem csak az átlagos hozamot $\left(A R_{i t}\right)$ modellezi, hanem helyt ad az időfüggő volatilitásnak is. A GARCH modellt széleskörüen alkalmazzák az irodalomban, és alkalmasnak bizonyult a részvény árfolyam eloszlásának magyarázatára (BOLLERSLEV, ENGLE \& WOOLDRIDGE, 1988; FRENCH, SCHWERT \& STAMBAUGH, 1987; BAILLIE \& DEGENNARO, 1990).

Egy másik vitatott téma az, hogy a részvény hozamokra vonatkozó regressziók ritkán mutatnak normális eloszlású hibatényezőket (FAMA, 1963). Valójában a részvényhozamok eloszlása túlzott mértékủ csúcsosságot (kurtozist) mutat, azaz leptokurtikus. A feltételes normális eloszlású GARCH modell megengedi, hogy a feltétel nélküli hibaeloszlás leptokurtikus legyen, azonban nem képes teljesen magyarázni az észlelt nagymértékủ kurtozist (CORHEY \& RAD, 1996). Az irodalom általában elfogadja, hogy a Student t-eloszlás hatékonysága jobb (BAILLIE \& BOLLERSLEV 1989, HSIEH 1989). Újabban MCKENZIE, THOMSEN \& DIXON (2004) szimulációkat végzett a napi várható hozamokat használva, hogy felbecsülje a statisztikai esettanulmányokból következtethető pontosságot. A vizsgált módszerek közt volt az állandó átlagos hozam model, a regressziós modellek OLS-sel, GARCH $(1,1)$ normális hibával és GARCH (1,1) Student-t hibával. Kimutatták, hogy a regressziós modellek jóval használhatóbbak, mint az állandó átlagú hozam model. Megállapították továbbá, hogy a GARCH 
modellekkel végzett vizsgálati statisztika hatékonyabb, mint az OLS módszer, és kismértékü abnormális teljesítmény esetén a Student-t eloszlású GARCH $(1,1)$ model bizonyult következetesen a leghatékonyabbnak.

\subsection{A témakör kutatási eredményeinek áttekintése}

Számos kutató elemezte a tőkepiac reakcióját mind a pozitív mind a negatív a környezeti eseményekre. Bár ezekben a kutatásokban általában arról számoltak be, hogy vállalatok a piaci érték csökkenését tapasztalták a kedvezőtlen környezeti hírek bejelentését követően, míg a jó környezeti hírek ellenkező hatást váltottak ki, ezek a tapasztalatok nem voltak egyöntetüek.

HAMILTON (1995), KONAR és COHEN (1997), KING és LENOX (2001), CLARKSON et al. (2008) a Toxikus Kibocsátás Leltárának (Toxic Release Inventory, TRI) nyilvánosságra hozására adott reakciókat vizsgálták. LAPLANTE és LANOIE (1994) valamint KLASSEN és MCLAUGHLIN (1996) a sajtó környezeti híreire adott piaci reagálásokat tanulmányozták. Míg Klassen és McLaughlin a harmadik féltől adományozott környezeti díjakra szignifikáns pozitív piaci reakciókról számoltak be, addig GILLEY et al. (2000) a környezeti folyamatok javítására adott piaci reakciókat vizsgálva negatív eredményeket kaptak. Klassen és McLaughlin szintén igazolva látták, hogy a tőzsdei hozamok aszimmetrikusan reagálnak a környezeti hírekre. A részvények árának növekedése egy vállalat pozitív környezeti bejelentésére nem olyan mértékü, mint az árak esése negatív események hírére. Egy későbbi tanulmányban KONAR és COHEN (2001) kimutatta, hogy az a cég, amely kevesebb toxikus vegyi anyagot bocsájt ki vagy kevesebb környezeti perrel fenyegetett, várhatóan nagyobb Tobin's Q-t ér el. 2002-ben írt közleményükben KING és LENOX állították, hogy valójában a szennyeződés megelözése és nem annak helyrehozása eredményezi a jobb értékhozamot.

NICOLAU et al. (2001) szignifikáns pozitív reakciót mutatott ki a vállalat ISO 9000 tanúsítványának hírére, azonban PAULRAJ és de JONG (2011) éppen ellenkező választ kapott az ISO 4001 tanúsítvánnyal kapcsolatban. LANOIE et al. (1998), GUPTA és GOLDAR (2005), és DASGUPTA et al. (2006) nemzeti kormányok által kiadott szennyezők listáját vizsgálta és azt találták, hogy piac bünteti azokat a vállalatokat, amelyek kevésbé környezetbarátnak tekinthetök. MUOGHALU et al. (1990) a veszélyes hulladék helytelen lerakása miatt folytatott perek hatását vizsgálta a tőkepiacra és megállapította, hogy a cégek jelentős veszteségeket szenvedtek. KARPOFF et al. (2005) viszont úgy véli, hogy a részvényesi érték csökkenése mindössze a 
büntetés tényleges mértékével egyenesen arányban csökken. A különböző eredmények arra engednek következtetni, hogy a piac nem értékeli egyformán a környezeti törekvéseket és a szabályok áthágását. KING és BAERWALD (1998) szerint az egyedi vállalati jellemzők befolyásolják, hogy a vállalatok a környezeti teljesítményüket hogyan jelentik le illetve azt a piaci elemzők hogyan értékelik. Újabb tanulmányok (CORMIER \& MAGNAN, 2007; WAGNER 2010, HORVÁTHOVÁ 2010) megerősítik, hogy az eltérő vizsgálati kimenetelek a cégek különböző jellegzetességeinek is tulajdoníthatók. A cégszintű jellemzők között a leggyakrabban vizsgáltak a cég mérete, az iparág illetve a piaci kockázat (BEURDEN \& GOESSLING, 2008). A piaci kockázatot a bétával, míg a vállalat méretét a bevétellel vagy az eszközökkel modellezik. A likviditási hányados (adósság/részvénytőke arány) egy másik gyakran vizsgált mutató (WADDOCK \& GRAVES 1997). Számos kutató arra a következtetésre jutott, hogy azon elemzések, amelyek több iparágat ölelnek fel bizonytalan kimenetelüek az iparágak közötti nagy mértékü eltérések miatt, és ezért a kutatásoknak csak meghatározott iparágakra kellene fókuszálniuk (GRIFFIN \& MAHON 1997, CHAND 2006). Előző kutatások szintén kimutatták, hogy a nagymértékben szennyező iparágakban tevékenykedő cégek sokkal nagyobb figyelmet fordítanak a környezeti teljesítményük nyilvánosságra hozatalára (HALME \& HUSE 1997, DEEGAN \& GORDON 1996). Habár az élelmiszeripart eddig nem sorolták a tradicionálisan szennyező iparágak közé, ez a megítélés gyorsan változik. Az élelmiszer termelés magas környezeti kihatása ellenére, eddig kevés tanulmány foglalkozott az iparággal, és különösen a környezeti és pénzügyi teljesítmény közötti összefüggésekkel. HARTMANN 2008as cikkében a CSR és élelmiszeripar általános összefüggéseivel foglalkozott, kiemelve a vállalatok kommunikációjának fontosságát. MALONI \& BROWN (2006) és PESONEN et al. (2011) az ellátási lánc illetve az élelmiszerlánc egészét vizsgálták a vállalti felelősség és a környezetvédelem szempontjaiból. THOMSEN \& MCKENZIE (2001), WANG et al. (2002) és KONG (2012) élelmiszerszennyeződési botrányok tőzsdei kihatásaival foglalkoztak. Megint mások regionális jellegzetességeket taglaltak (ODOR 2009 Magyarország, JONES et al. 2008 az Egyesült Királyság, míg GUTHRIE et al. 2008 az Ausztrál élelmiszeripart vizsgálta).

Bár a legtöbb vizsgált cég-jellemző pénzügyi vagy üzlet specifikus jellegü (mint a méret, $\mathrm{K}+\mathrm{F}$ ráfordítás, hirdetés hatékonysága, kockázatosság, eszközök, iparág, ország stb.), a telekommunikáció nagymértékü proliferációja, valamint a környezetvédelem és fenntarthatóság témakörének növekvő sajtó visszhangja elengedhetetlenné teszi a média szerepének vizsgálatát. 
DASGUPTA et al. (2006) szerint minél nagyobb figyelem fordult az újságokban bizonyos negatív eseményekre, annál jobban csökkent a cég piaci értéke. Ezt természetesen befolyásolhatja az, hogy a jelentősebb események (pl. Deep Water Horizon eset) természetüknél fogva nagyobb sajtófigyelmet kapnak. AERTS et al. (2008) a média szerepét vizsgálva a közvélemény formálására úgy találta, hogy a média nyilvánossága jelentős meghatározó erőt jelent a környezeti teljesítmény közzétételében, vagyis a környezeti hírek mennyisége befolyásolja a vállalat környezeti kockázatosságát. Egy 30 év vizsgálatait áttekintő metaelemzésben ORLITZKY et al. (2003) arról számolt be, hogy a reputáció fontos közvetítő tényező a társadalmi és pénzügyi teljesítmény viszonya között. Megállapították továbbá, hogy külső elemzők véleménye jobban látszik befolyásolni a pénzügyi eredményeket, mint a vállalatok saját kommunikációi. KARPOFF et al. (2005) azonban úgy vélte, hogy a környezeti szabályok megszegéséért járó reputációs veszteségek nem annyira jelentősek, mint a büntetőjogi cselekményekből adódóak. BANSAL és CLELLAND (2000) másrészt amellett érvelt, hogyha egy vállalat nagy környezeti legitimációt szerzett (pl. múltbeli teljesítményéből a befektetők tudják, hogy egy-egy negatív eset rendkívüli), úgy az védve lesz a negatív események teljes erejétől. A média befolyásának illetve a cég imázsnak fontosságára utaló bizonyítékok a stratégiai vállalatvezetés erőforrás-alapú (resource-based view) teóriáját támasztják alá, mely szerint egy vállalat azon képessége, hogy környezetvédelmi problémáit és imázsát a vele egy üzletágban lévőknél jobban menedzseli magasabb megtérülési rátákat eredményez (lásd BARNEY, 1986 és WERNERFELT, 1984).

Jóval kevesebb cikk foglalkozik specifikusan, a piaci eredmények időbeli eltérésével, vagyis, hogy változnak-e az abnormális hozamok, ha különböző időpontokban vizsgáljuk őket. Ez a kérdés inkább csak részeredményként, vagy a kutatások mellékágaként tünik fel. DASGUPTA et al. (2006) arra a következtetésre jutott, hogy a negatív eseményekre adott átlagos abnormális hozamok változnak az idő függvényében. Kutatásuk az 1992 és 2000 év közötti időtartamot öleli fel. BLANCARD és LAGUNA (2009), a vegyi katasztrófákat vizsgálva 1995 és 2005 között, viszont nem talált szignifikáns eltérést a kiválasztott mintaperiódusok között. CLIMENT és SORIANO (2011) zöld befektetési alapok hozamait hasonlították össze az általános SRI piaccal 1987 és 2009 között, és a hozamokat az utolsó periódusban magasabbnak találták. A különbséget a zöld befektetési alapok népszerüségének növekedésével, illetve a gazdasági válsággal magyarázták. Hozzájuk hasonlóan más kutatók is vizsgálták ugyanazon 
vállalat-csoportokból képzett portfoliók hosszútávú teljesítményét. OGDEN és WATSON (1999) egy tíz éves hosszútávú tanulmányban víz-szolgáltató cégeket vizsgáltak, míg GARCIACASTRO et al. (2008), egy hét éves időtartamú, de szélesebb vállalati körben folytatott kutatást. Mindketten arra a következtetésre jutottak, hogy az így képzett portfoliók rövidtávon veszteségesnek, míg hosszú távon nyereségesnek bizonyultak. Szerintük a különbség a vállalatok zöld befektetéseihez szükséges magas kezdeti tőkeigénynek köszönhető.

Számos kutató szerint, egy egyetemes, mindenki által elfogadható üzleti modell a vállalati társadalmi szerepvállalás mellett vagy ellen gyakorlatilag elérhetetlen (ROWLEY \& BERMAN 2000, MARGOLIS \& WALSH 2003, SCHRECK 2011). Újabb tanulmányok azonban amellett érvelnek, hogy egy jól kivitelezett CSR üzletpolitika, vagyis amely a CSR azon aspektusaira fókuszál, amelyek a megfelelő időpontban a legtöbb hasznot tudják hajtani, igenis jobb pénzügyi teljesítményhez vezethet (MAROM 2006, BIRD et al. 2007). 


\section{CÉLKITŰZÉSEK}

\subsection{A kutatás fó irányai}

$\mathrm{Az}$ irodalmi feldolgozásban részletes betekintést nyújtottam a témakört érintő főbb közgazdaságtani irányzatokról illetve a pénzügyi és környezeti teljesítmény összefüggéseit vizsgáló kutatások eddigi eredményeiről és irányvonalairól. Kitekintettünk az etikus befektetési alapok és a média szerepére, illetve az élelmiszeripar jelenlegi problémáira, környezetünkre és fogyasztási szokásainkra gyakorolt hatására. Egyfelől a környezettudatos gazdálkodás, mint az etikus befektetési alapok által vizsgált vállalati társadalmi teljesítmény egyik pillére fontos szerepet játszik abban, hogy egy cég milyen megítélés alá esik a befektetők részéről. Másfelől, a fenntartható fejlödés előtérbe kerülésével, mind a kormányok mind a fogyasztók részéről, az élelmiszeripar fokozottan a figyelem középpontjába került a fenntartható termelés és fogyasztás szempontjából is.

Kutatásom két fö irány, egy transzverzális és egy longitudinális vizsgálat, és ezen belül is három föbb kérdéskör köré csoportosítható. A transzverzális elemzés során elsősorban arra voltam kíváncsi, hogy a vállalatokkal kapcsolatos környezeti hírekre egyformán reagál-e a piac. Hogyan itélik meg a befektetöi körök a vállalatok környezetvédelmi és fenntarthatósági törekvéseit? Vajon a negatív, büntető jellegü események, mint az állami beavatkozások, pereskedések vagy a proaktív, pozitív vállalatok által kezdeményezett programok játszanak nagyobb szerepet? Egyforma elbírálás alá esnek-e a környezetvédő lejárató kampányok illetve jó hírnevet erősítő zöld besorolások?

A keresztmetszeti elemzés második része arra irányult, hogy kiderítsem mely vállalati szintű (a vállalatra specifikusan jellemző) mutatók befolyásolják a piaci döntéseket. Mivel ugyanazon iparág szereplőit vizsgáltam, amelyek ráadásul ugyanazon piac szereplői is, egyes az összes vállalatra kiható tényezőket kizárhattam. Azonban számos vállalati szintủ pénzügyi mutató, mint a méret, profitabilitás, az eladósodás mértéke vagy a piac többi részéhez viszonyított kockázat befolyásolhatja, hogy a befektetők egyes hírekre hogyan reagálnak. A pénzügyi mutatók mellett fontosnak tartottam, hogy a megvizsgáljam a vállalatok környezeti megítélését is. Itt két vállalati szintủ mutatót, a vállalat médialefedettségét illetve a vállalat 
imázsát vontam be az elemzésbe. Fontos kiemelni, hogy médialefedettség alatt itt nem a specifikus hírek által kiváltott médiareakciót, hanem magára a vállalatra irányuló általános figyelmet vizsgáltam.

Harmadik kutatási témaköröm a környezeti hírek megítélésének időbeli változására irányult. A környezetvédelem és fenntarthatóság kérdése az elmúlt két évtizedben jelentős változáson esett át. Egyfelől megnövekedett a téma sajtóvisszhangja, másfelől magának a témakörnek a megítélése is sokkal pozitívabb lett. Magának az élelmiszeriparnak a fenntartható fejlődésben betöltött szerepe is egyre nyilvánvalóbbá vált. Ezen változások erőteljesen befolyásolhatják a piaci reakciókat. Ezért az élelmiszeripari vállalatok környezeti híreinek és tőzsdei adatainak elmúlt húsz évre vonatkozó longitudinális elemzését végeztem el.

Kutatásom huszonhárom nagy, nemzetközi élelmiszervállalatot ölel fel. Vizsgálatom során összegyüjtöttem és elemeztem ezen vállalatok tőzsdei, pénzügyi, és sajtó anyagait. A statisztikai feldolgozásban jelentős elörelépést jelentett, hogy kutatók a pénzügyi idősor elemzésekre használt fejlettebb módszereket erre a témakörre is adaptálták. Dolgozatomban ezért a GARCHmódszert alkalmazom, mely figyelembe veszi a tőzsde olyan sajátosságait, mint a volatilitás vagy a klasztereződés. 


\subsection{Kutatási hipotézisek}

Hipotéziseimet a témakörben megjelent nagyszámú publikáció tanulmányozására és feldolgozására, hazai és külföldi egyetemek professzoraival végzett személyes konzultációkra illetve a fent vázolt föbb irányelvekre alapoztam. Munkámban arra törekedtem, hogy megvizsgáljam a környezeti hírek hatását az élelmiszeripari vállalatok részvény áraira különös tekintettel a következőkre:

$\mathrm{H}_{1}$ : A piac nem reagál minden környezeti hírre egyformán. Várható, hogy a piac bizonyos hírcsoportokra egyáltalán nem reagál, mivel azokat nem tekinti értékteremtőnek vagy rombolónak.

$\mathrm{H}_{2}$ : Különbözö vállalati szintü pénzügyi jellemzők, mint méret, profitabilitás, vagy kockázat, befolyásolják a piac reakcióját. Várható, például, hogy a kisebb, veszteségesebb cégek jobban ki vannak téve a piac reakcióinak, mint a nagyobb, profitábilisabbak.

H3: A média figyelme befolyásolja a piaci reakciókat. Várható, hogy a közleményekben kevésbé gyakran szereplő vállalatokat erősebb piaci reakciók érik, mint a folyamatosan a figyelem előterében állókat.

$\mathrm{H}_{4}$ : A cég környezeti reputációja befolyásolja a piaci reakciókat. Várható, hogy a jó környezeti hírnév megvédi a vállalatokat a negatív események által kiváltott kedvezőtlen tőzsdei reakciók teljes hatásától.

H5: A piaci reakciók változnak az idö függvényében. Várható, hogy a környezetvédelmi témakör előtérbe kerülésével, illetve a nyilvánosság növekedésével a piac reakciói diferenciáltabbakká váltak. 


\section{ANYAG ÉS MÓDSZER}

\subsection{A nemzetközi élelmiszervállalatok és statisztikai jellemzőik}

A kezdeti adatgyüjtés egy nagyobb, ötven nagy nemzetközi élelmiszeripari vállalatot felölelő, adatbázis létrehozásával indult (ld. Mellékletek: Vállalati Adatbázis). Az adatbázist a Dunn\&Bradstreet illetve a Hoover segítségével állítottam össze. A vállalatok a New-yorki tőzsdén (NYSE) és NASDAQ-on jegyzett, egy millió dollárnál nagyobb árbevételü cégek, melyek az elsődleges ipari kód (SIC, Standard Industrial Classification) szerint harminchárom élelmiszeripari ágazatot foglalnak magukba (12. ábra).

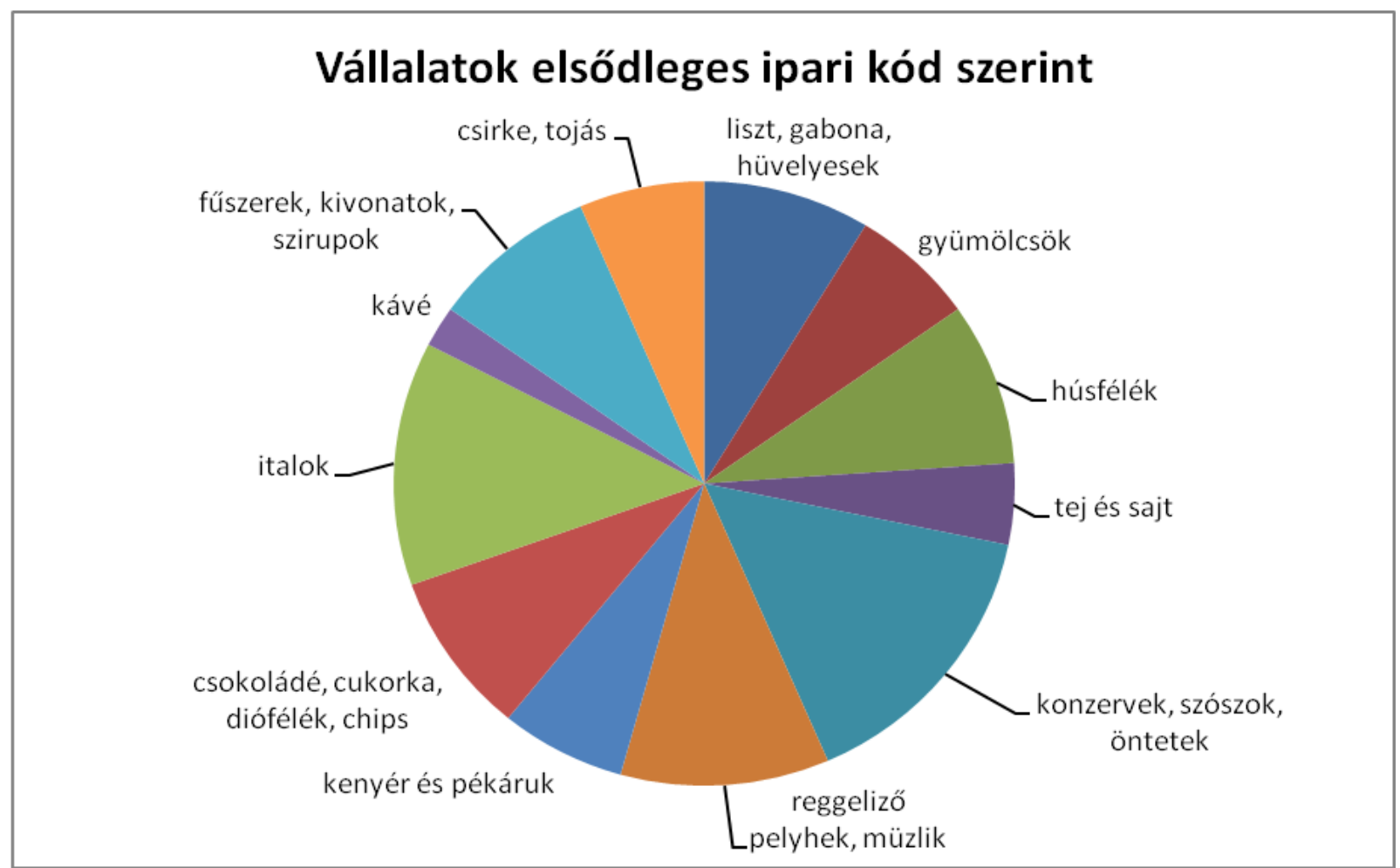

12. ábra A vizsgált vállalatok élelmiszertermelési ágazat szerint

A felmérés nem tartalmaz dohányipari, és szeszes italokat gyártó cégeket, tekintve, hogy ezek természetüknél fogva a reputációs skála alsó részén állva túlságosan egy irányba befolyásolnák az eredményeket. Az adatbázist a továbbiakban le kellett szükítenem azon vállalatokra, melyek a vizsgált időtartam alatt (1990 január és 2010 decembere között) piacra 
dobásuk óta folyamatosan és legalább öt éven keresztül forgalmaztak, illetve tőzsdei indexük szerint is önálló vállalatoknak számítanak.

Második lépésként, egy a környezeti teljesítménnyel kapcsolatosan általánosan használt szavak és kifejezések listájának segítségével, a Wall Street Journal Factiva adatbázisából letöltöttem mindazon hírcikkelyeket, melyek az így létrehozott keresőlánc kritériumainakának megfeleltek (5. táblázat).

5. táblázat A Factiva adatbázisban felhasznált kulcsszavak jegyzéke

\begin{tabular}{|c|c|c|c|c|}
\hline accident & contribut* & footprint & NRDC & resolution \\
\hline accomplish* & council & foundation & order & resource \\
\hline $\operatorname{act} *$ & CSR & gift & outstanding & responsib* \\
\hline activist & decree & global & patent & reuseable \\
\hline admire & defense & grant* & penal* & reward* \\
\hline admirable & department & great* & PERI & SA8000 \\
\hline admiration & design & green* & pledge & scorecard \\
\hline advantage & disaster & GRI & policy & scrutin* \\
\hline agency & disclosure & honor* & pollut* & settle* \\
\hline air & discovery & idea & principle* & social $*$ \\
\hline analysis & distinction & incident & priorit* & spill \\
\hline announce* & donat* & index & prize & star \\
\hline approv* & dump & initiative & program & stewardship \\
\hline award & earth & innovat* & progress & study \\
\hline best & eco* & institute & project & success* \\
\hline boycott & eco-friendly & invent* & public & suit \\
\hline breakthrough & ecolog* & involvement & quali* & super* \\
\hline carbon & effort & ISO 14001 & Rainforest & support \\
\hline celebrat* & emission & issue & rall* & sustainab* \\
\hline center & EMS & justice & $\operatorname{rank}^{*}$ & system \\
\hline CERCLA & endeavor & lawsuit & ranking & tags \\
\hline CERES & endow* & leader* & recogn $*$ & technolog* \\
\hline certifi* & energy & LEED & recovery & tort \\
\hline change & environment* & list & recycl* & toxic \\
\hline clean* & EPA & litigation & regulat* & tribute \\
\hline concern* & ethi* & management & renewable & violation \\
\hline consent & example & model & report & warming \\
\hline conserv* & excellen* & natur* & reputation & water \\
\hline consult* & executive & Newsweek & research & win, won \\
\hline contaminat* & fine* & NPL & & \\
\hline
\end{tabular}


A kulcsszavak segítségével, így a több mint hatszázezer általános cikkből ezerre sikerült leszükíteni a környezetvédelmi témakörbe tartozó híreket. A cikkek letöltése után, az értékelhetőség kedvéért, csak azon vállalatok maradtak az adatbázisban, melyeknél legalább húsz vagy annál több környezeti hírt találtam. Azon események esetében, ahol több újság, illetve ugyanazon újság de többször is, közölte a hírt csak a legkorábbi dátummal megjelent cikk került az adatbázisba. Azok a napok, amikor több esemény is történt ugyanazon a napon, illetve az eseményablakok átfedték egymást szintén kimaradtak, mivel ilyen esetekben nem lehet megállapítani, hogy a tőzsdei reakciót melyik esemény váltotta ki. Szintén ki kellett zárnom azon napok eredményeit, amikor más fontos, zavaró események - akvizíció, osztalék, negyedéves profit jelentések stb. - történtek. Az így véglegesített adatbázisban huszonhárom vállalat, 880 értékelhető eseménye állt rendelkezésemre.

A vállalati adatbázis elkészítésekor figyelembe vettem a vállalat méretén (árbevétel és tőkepiaci érték) kívül, annak profitabilitását (sajáttőke-arányos megtérülés mutató: ROE, árfolyam/nyereség arány: $\mathrm{P} / \mathrm{E}$ ), likviditását (adósság/részvénytőke arány: LEV) és kockázatosságát (értékpapír volatilitás: béta). A pénzügyi jellemzőket a Dunn\&Bradstreet adatbázisából nyertem (6. táblázat).

6. táblázat A vizsgált élelmiszeripari vállalatok leíró statisztikai adatai $(\mathrm{N}=23)$

\begin{tabular}{|c|c|c|c|c|c|c|c|}
\hline & $\begin{array}{l}\text { Tőkepiaci } \\
\text { érték } \\
\text { (Millió } \\
\text { USD) }\end{array}$ & $\begin{array}{l}\text { Eszközök } \\
\text { (Millió } \\
\text { USD) }\end{array}$ & $\begin{array}{l}\text { Bevétel } \\
\text { (Millió } \\
\text { USD) }\end{array}$ & $\begin{array}{l}\text { Adósság/ } \\
\text { részvénytőke } \\
\text { arány } \\
(\mathrm{LEV})\end{array}$ & Béta & $\begin{array}{l}\text { Árfolyam/ } \\
\text { nyereség } \\
\text { arány } \\
(\mathrm{P} / \mathrm{E})\end{array}$ & $\begin{array}{l}\text { Sajáttőke- } \\
\text { arányos } \\
\text { megtérülési } \\
\text { mutató (ROE) }\end{array}$ \\
\hline Átlag & 13486 & 9632 & 10587 & 0,88 & 0,81 & 19,81 & 20,77 \\
\hline Medián & 3710 & 4080 & 3960 & 0,68 & 0,61 & 16,29 & 13,88 \\
\hline Szórás & 28188 & 14812 & 15200 & 0,82 & 0,62 & 14,73 & 17,99 \\
\hline Minimum & 337 & 484 & 499 & 0,00 & 0,10 & $-0,06$ & 2,86 \\
\hline Maximum & 145170 & 66710 & 61682 & 3,97 & 3,08 & 85,47 & 83,95 \\
\hline
\end{tabular}

Az élelmiszer iparág nagymértékben telített, mivel a négy legnagyobb részvevő (Nestlé, Unilever, Kraft, és Danone) a harminc legnagyobb élelmiszeripari vállalat piaci tőkésítésnek több mint ötven százalékát teszi ki (EUROSIF, 2010). A kutatásomban felhasznált cégminta 
ezért az iparágra nézve reprezentatívnak tekinthető, mivel az átlag cégméret tökepiaci érték szerint 13 milliárd dollár felett van, így a piaci kapitalizáció nagy részét lefedi, míg az átlag P/E ráta által kifejezett nyereségesség 20 körül mozog, ami szintén megfelel az iparág átlagának. Ezen túl a 23 vállalatból 21 képviselteti magát a Dow Jones élelmiszer és ital indexének (DJUSFB) negyvenkét vállalatából, ami súlyozás szerint az index 78,6\% teszi ki.

\subsection{A változók és alcsoportok bemutatása}

A függő változó, vagyis a tőzsdei értékben létrejött változás kiszámításához szükségem volt a vállalatok húsz évre visszamenő tőzsdei adataira, illetve egy átlag piaci értéket megfelelően kifejező, megközelítő értékre, melyre a Standard and Poor's (S\&P) 500 index értékeit használtam. Ezen adatokat a Yahoo! Finance segítségével gyüjtöttem össze.

Az elemzés keresztmetszeti (transzverzális) illetve időbeli (longitudinális) elvégzéséhez ezen túl létre kellett hoznom különböző független változó csoportokat.

A transzverzális elemzést két oldalról közelítettem meg. Elsősorban az eseménytípusok különbözőségére voltam kíváncsi, és másodsorban a tőzsdei reakciót befolyásolható egyéb vállalati szintủ változók szempontjából közelítettem meg a problémakört.

Az eseményeket tekintve, az összegyüjtött környezeti hírek különbözö, mind pozitív mind negatív, hírekből állnak össze, így a piac reakciója is eltérő lehet a különböző eseménytípusoktól függően. A tőzsde, például, általában, sokkal erősebben reagál a negatív hírekre, mint a pozitívokra. Ha az összes hír aggregátumát elemeznénk, a hír elöjelének figyelembevétele nélkül, akkor a különböző előjelü események elnyomnák egymást és statisztikailag inszignifikáns eredményeket produkálnának. A különböző események hatásának elkülönítéséhez ezért, az előzetes elvárások szerint, a mintát először egy pozitív és negatív hírhalmazra választottam szét, majd a további differenciálás érdekében, ezeket tovább bontottam egy belső illetve egy külső eseménycsoportra, aszerint, hogy a hír a vállalat belső tevékenységeinek közvetlen eredménye, vagy pedig külső elemzők és megfigyelök közvetett, szubjektív véleményét tükrözi. Így a következő négy alkategóriát kaptam: 
1-es típusú esemény (E1): A vállalat belső müködéséből eredő vállalat ellen irányuló büntetések, állami intézkedések, perek stb.

2-es típusú esemény (E2): A vállalatok által kezdeményezett környezeti megítélést, vagy tényleges környezeti teljesítményt javító belső intézkedések.

3-as típusú esemény (E3): Különböző, külső megítélők által a vállalatnak odaítélt díjak, elismerések, rangsorolások stb.

4-es típusú esemény (E4): Egyéb, külső erők által kezdeményezett, negatív események (bojkottok, jelentések stb.)

A 2-es és 3-as típusú események pozitív megítélésủek, amíg az 1-es és 4-es típusúak negatívak. E1 és E2 a vállalat belső döntéseire és cselekedeteire fókuszál, míg E3 és E4 külső megítélők véleményeit tükrözi.

A cég specifikus mutatók elérhetősége, és nagymértékü volatilitása miatt a vállalatok pénzügyi mutatóit, média lefedettségét illetve reputációs rátáját csak az elmúlt négy évre visszamenőleg (2007-2010) tudtam vizsgálni. Így a keresztmetszeti elemzés második részéhez összesen a huszonhárom vállalat 556 eseménye állt rendelkezésemre. Az elemzés elvégzéséhez, a cég-specifikus muatatókat megfelelő csoportokra kellett bontanom, még pedig oly módón, hogy mindegyik csoportban értékelhető számú hírcikkely maradjon.

A pénzügyi mutatók a már fent említett Dunn\&Bradstreet adatbázisából származnak. Az irodalmi áttekintésre alapozva, ezek közül az eszközállományt (assets, A), a likviditási (leverage, LEV) és rizikó (béta, B) faktorokat, illetve a profitabilitást (Return on Equity, ROE) választottam. A csoportosításhoz, értelemszerüen, a pénzügyi mutatók általánosan elfogadott mértékegységeit használtam.

A vállalatok média lefedettségét (coverage, COV) a nyomtatott médiában megjelenő környezetvédelemmel kapcsolatos cikkek számával mértem. A skála itt húsztól (a legkevesebb számú hír, amivel egy vállalat az adatbázisban szerepelhetett) egészen a valamivel 100 fölötti értékig mozgott.

A környezeti imázst (reputation, REP) egy átlag zöld pontszám, "green score” (1-100-ig terjedő skálán), kiszámításával hoztam létre, melyet a médiában megjelenő (Newsweek, CRO Magazin), NGO-któl (CERES, CDP), illetve befektetői alapoktól (Maplecroft, KLD) származó különböző felmérésekből nyertem. E sorok írásakor 23 különböző fentarthatósági rangsorolás 
volt elérhető, azonban nem mindegyik nyilvánosan vagy ingyenesen elérhető. Habár egyes besorolások már a 2000-es évtöl léteznek, én a folyamatosságra és a szabványosításra törekedtem, így csak a fennt említett hat rangsort használtam.

Az így kapott adatokból kategóriánként három-három csoportot hoztam létre, ahol az egyes mutató mindíg a legjobb, a hármas a legrosszabb, míg a kettes a középmezőnyt képviselte. A transzverzális elemzéshez így hat vállalati szintü mutatót (négy pénzügyi és két nem pénzügyi kategóriát), és ezen belül hármas csoportokat nyertem, melyek lebontását a 7-os táblázatban láthatjuk.

7. táblázat Vállalati szintủ mutatók kategóriák és csoportok szerinti lebontása

\begin{tabular}{|c|c|c|c|c|}
\hline Kategória & Csoport & Skála & $\begin{array}{c}\text { Vállalatok } \\
\text { száma }\end{array}$ & $\begin{array}{c}\text { Események } \\
\text { száma }\end{array}$ \\
\hline \multirow{3}{*}{ 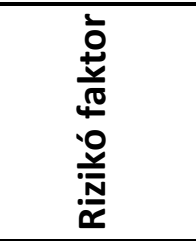 } & B1 & $>1.2$ & 5 & 97 \\
\hline & B2 & $1.2-0.6$ & 7 & 193 \\
\hline & B3 & $<0.6$ & 11 & 266 \\
\hline \multirow{3}{*}{ 营 } & LEV1 & $>0.75$ & 11 & 216 \\
\hline & LEV2 & $0.75-0.5$ & 5 & 174 \\
\hline & LEV3 & $<0.5$ & 7 & 166 \\
\hline \multirow{3}{*}{ 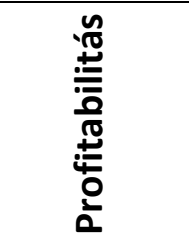 } & ROE1 & $>25$ & 9 & 218 \\
\hline & ROE2 & $25-10$ & 7 & 215 \\
\hline & ROE3 & $<10$ & 7 & 123 \\
\hline \multirow{3}{*}{ 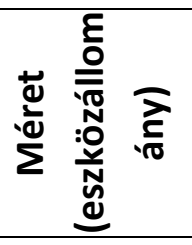 } & $\mathrm{A} 1$ & $>15$ & 7 & 234 \\
\hline & $\mathrm{A} 2$ & $15-5$ & 9 & 221 \\
\hline & A3 & $<5$ & 7 & 101 \\
\hline \multirow{3}{*}{ 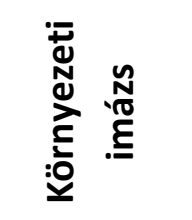 } & REP1 & $>55$ & 8 & 240 \\
\hline & REP2 & $55-30$ & 9 & 189 \\
\hline & REP3 & $<30$ & 6 & 127 \\
\hline \multirow{3}{*}{ ¿ } & Cov1 & $>30$ & 6 & 223 \\
\hline & cov2 & $30-20$ & 7 & 200 \\
\hline & cov3 & $<20$ & 10 & 133 \\
\hline
\end{tabular}


Legvégül pedig a longitudinális elemzéshez a teljes 1990-2010 közötti idő futamot vettem alapul, ahol is a négy eseménykategóriát külön-külön akartam vizsgálni (8. táblázat).

8. táblázat A környezeti események megoszlása esemény típus és év szerint (longitudinális elemzés)

\begin{tabular}{|c|c|c|c|c|}
\hline \multirow[b]{2}{*}{ Év } & \multicolumn{4}{|c|}{ Esemény Típus } \\
\hline & E1 & E2 & $\mathbf{E 3}$ & $\mathbf{E 4}$ \\
\hline 2010 & 11 & 99 & 67 & 9 \\
\hline 2009 & 10 & 71 & 50 & 7 \\
\hline 2008 & 15 & 60 & 24 & 18 \\
\hline 2007 & 15 & 36 & 26 & 9 \\
\hline 2006 & 10 & 28 & 21 & 8 \\
\hline 2005 & 20 & 11 & 13 & 10 \\
\hline 2004 & 10 & 13 & 4 & 8 \\
\hline 2003 & 21 & 12 & 6 & 4 \\
\hline 2002 & 15 & 4 & 2 & 6 \\
\hline 2001 & 16 & 5 & 1 & 5 \\
\hline 2000 & 8 & 3 & 2 & 4 \\
\hline 1999 & 8 & 2 & 3 & 3 \\
\hline 1998 & 18 & 3 & 0 & 2 \\
\hline 1997 & 5 & 0 & 1 & 0 \\
\hline 1996 & 6 & 1 & 0 & 2 \\
\hline 1995 & 3 & 0 & 0 & 1 \\
\hline 1994 & 2 & 0 & 0 & 0 \\
\hline 1993 & 4 & 0 & 0 & 1 \\
\hline 1992 & 3 & 1 & 0 & 0 \\
\hline 1991 & 1 & 4 & 0 & 2 \\
\hline 1990 & 2 & 5 & 0 & 0 \\
\hline
\end{tabular}


A mintát eredetileg egyforma időszakaszokra szerettem volna bontani és egy regressziós egyenlet keretében elemezni (ez volt az általános megközelítés az eddigi kutatásokban). Ez a megoldás azonban nem volt célravezető, mivel a különböző esemény típusok nem egyforma mintázatokat képeztek, így a közös idő-intervallumok használata nem hozott kiértékelhető eredményeket. Ezért, négy külön portfoliót képeztem a vizsgálandó eseményekre, és ezek kumulatív abnormális nyereség/veszteség hozamának alakulását elemeztem a húsz éves periódusban.

\subsection{Alkalmazott ökonometriai módszerek}

Három kutatási kérdésköröm kielégítő megválaszolásához némileg eltérő ökonometriai megközelítéseket kellett alkalmaznom, habár mindegyik módszer a GARCH regressziós egyenletek segítségével meghatározott három napra eső kumulált átlagos abnormális hozamok kiszámításán alapult. Mivel az előzetes tanulmányokban a $\operatorname{GARCH}(1,1)$ model a Student-t hibával bizonyult a legjobb hatásfokúnak, saját empirikus elemzésemben is ezt az ökonometriai elemzési módszert alkalmaztam. A keresztmetszeti elemzés első részéhez, vagyis az eseménytípusok közötti eltérések vizsgálatához, a 4-es számú egyenlet a következőként módosult:

$$
\begin{aligned}
& R_{i t}=\alpha_{i}+\beta_{i} R_{m t}+d_{1} E_{1}+d_{2} E_{2}+d_{3} E_{3}+d_{4} E_{4}+\varepsilon_{i t} \\
& \varepsilon_{i t} \sim t\left(0, h_{i t}, v\right) .
\end{aligned}
$$

A GARCH (1, 1) modellhez szükséges feltételes variancia egyenlet hozzáadásával:

$$
h_{i t}=\omega+\theta \varepsilon_{i, t-1}^{2}+\gamma h_{i, t-1}
$$

ahol $\varepsilon_{i t}$ a hibatényező a Student-t eloszlásból zéró átlaggal és $\mathrm{h}_{\mathrm{it}}$ varianciával; $\mathrm{R}_{\mathrm{it}}$ megfelel az $i$ cég napi részvényhozamának a $t$ napon, és $\mathrm{R}_{\mathrm{mt}}$ megfelel az $\mathrm{S} \& \mathrm{P} 500$ napi hozamának. A hozamok számítási módja: 


$$
R_{t}=100 \times\left(\ln \mathrm{P}_{\mathrm{t}}-\ln \mathrm{P}_{\mathrm{t}-1}\right),
$$

ahol $\mathrm{P}_{\mathrm{t}}$ vagy a vállalati részvény ára a $t$ napon, vagy az $\mathrm{S} \& \mathrm{P} 500$ index. Az összes számításhoz egy három napos esemény ablakot vettem tekintetbe úgy, hogy a dummy változó értéke az esemény napján, illetve egy nappal előtte és egy nappal utána 1 legyen, míg egyébként 0 . Természetesen a huszonhárom vállalathoz huszonhárom egyenletre volt szükség. Ezért az átlag iparági eredmény kiszámításához az egyenletekből nyert együtthatókat összesíteni kellett. Ehhez a SAVICKAS (2003) által kidolgozott és később JUNKER (2005) által is használt módszert alkalmaztam. Az egyenletekből nyert dummy együtthatókat $\left(\mathrm{d}_{1}-\mathrm{d}_{4}\right)$, vagyis az abnormális hozamok becsült átlagát, először is standardizálni kell:

$$
S_{i t}=\frac{\hat{d}_{i t}}{\sqrt{\hat{h}_{i t}}}
$$

A standardizált együtthatók átlaga pedig az összes vállalat eseménytípusonkénti átlagos abnormális hozamát eredményezi:

$$
S_{t}=\sum_{i=1}^{N} \frac{S_{i t}}{N}
$$

A megfelelő szignifikancia szintet az alábbi keresztmetszeti teszt statisztikából nyerjük:

$$
t=\sum_{i=1}^{N} \frac{S_{i t}}{N} / \sqrt{\frac{1}{N(N-1)} \times \sum_{i=1}^{N}\left(S_{i t}-\sum_{j=1}^{N} \frac{S_{j t}}{N}\right)} \cdot 2
$$

A vállalati szintű változók abnormális hozamokra való hatásának vizsgálatához ismét módosítani kell az egyenlet, úgy hogy az ugyanazon kategóriába eső vállalatok eseménytípus szerinti átlagos abnormális hozamai kiszámíthatóak legyenek: 


$$
\begin{aligned}
& R_{i j t}=\alpha_{j}+\beta_{j} R_{m t}+\sum_{k=1}^{4} \delta_{j k} E_{k t}+\varepsilon_{i j t} \\
& \varepsilon_{i j t} \sim t\left(0, h_{i j t}, v\right) \\
& h_{i j t}=\omega+\theta \varepsilon_{i j, t-1}^{2}+\gamma h_{i j, t-1},
\end{aligned}
$$

ahol $\varepsilon_{\mathrm{ijt}}$ a hibatényező a Student-t eloszlásból zéro átlaggal és $\mathrm{h}_{\mathrm{ijt}}$ varianciával; $R_{i j t}$ megfelel az $i$ cég napi részvényhozamának a $t$ napon, ami aj kategóriába esik, és $\mathrm{R}_{\mathrm{mt}}$ megfelel az S\&P 500 napi hozamának. $\mathrm{E}_{\mathrm{kt}} \mathrm{s}$ képviseli a négy dummy változót a fentiekben ismertetett eseményekre. Külön-külön megbecsültem az (8a) és (8c) egyenleteket mindegyik pénzügyi és a nem pénzügyi változóra, egyesítve az összes $j$ kategóriába eső cégre vonatkozó megfigyeléseket. Ez tizennyolc regressziós egyenlet lefuttatásával történt meg.

A 2.10-es szekcióban taglaltak miatt a hosszanti elemzést nem lehet egy regressziós egyenlet keretein belül megoldani. Ezért itt eltérő ökonometriai módszert kellett alkalmaznom. Az empirikus elemzéshez először is a standard esemény tanulmány módszeréből már jól ismert piaci modellt használtam (ld. 2. és 3. egyenlet) GARCH-ra módosítva. A regresszióból nyert abnormális hozamokból meghatároztam a három napra eső kumulált abnormális hozamokat:

$$
\operatorname{CAR}_{i}\left(t_{1}, t_{2}\right)=\sum_{t=t_{1}}^{t_{2}} A R_{i t}
$$

Az így kapott kumulált abnormális hozamokból a négy eseménytípusra létrehozott portfolió kronologikus grafikai megjelenítésére és annak elemzésére volt szükség. Ezek után arra voltam kiváncsi, hogy a látható törésvonalak mentén létrehozott időintervallumokba eső abnormális hozamok szignifikánsan eltérnek-e egymástól. Ezért először is a csoportok mediánjának eltérését vizsgáltam Kruskal-Wallis teszttel, majd post-hoc elemzésként Mann-Whitney páronkénti összehasonlítást végeztem. A páronkénti összehasonlítás nagy száma miatt az esetleges elsőfajú hiba esélye jelentős, ezért az analízist Bonferroni korrigált formában is lefuttattam. 


\section{KUTATÁSI EREDMÉNYEK}

\subsection{Transzverzális elemzés}

A keresztmetszeti elemzéssel célom a négy eseménytípusra adott reakciók, illetve a reakciókat esetlegesen befolyásoló vállalati szintủ változók hatásának vizsgálata volt.

\subsubsection{Környezeti események típusa szerint}

Első lépésben a tőzsde reakcióit a különböző környezeti hírek típusa szerinti elemeztem. Az események típus szerinti lebontását a 9. táblázatban láthatjuk.

9. táblázat A környezeti események megoszlása eseménytípus szerint

\begin{tabular}{cc}
\hline Típus & Esemény \\
\hline E1 & 203 \\
E2 & 358 \\
E3 & 220 \\
E4 & 99 \\
\hline
\end{tabular}

E1 és E2 típusú események a vállalat belső döntéseire és cselekedeteire fókuszálnak, míg az E3 és E4-esek a külső megítélők véleményeit tükrözik. A 2-es és 3-as típusú események, a priori, pozitív megítélésűek, amíg az 1-es és 4-es típusúak negatívak. A legtöbb közlemény a két pozitív kategóriából került ki. Mint az várható is, a vállalatok nyilvánvalóan nagy hangsúlyt helyeznek a kedvezőtlen hírek visszatartására, míg szívesen veszik, és önmaguk is gyakrabban jelentik azon eseményeket, melyek jó színben tüntetik fel őket.

Elöször is a vállalatok összesített eredményét számoltam ki. A négy kiválasztott eseménytípus három napra eső aggregált kumulált abnormális hozama (CAR) és annak szignifikanciája az összes vizsgált élelmiszeripari vállalatra a 10. táblázatban látható. 
10. táblázat Eseménytípus szerinti átlagos abnormális hozamok és szignifikancia szintjük

\begin{tabular}{c|cccr}
\hline & E1 & E2 & E3 & \multicolumn{1}{c}{ E4 } \\
\hline CAR & -1.0431 & 1.0539 & 0.1154 & -0.2605 \\
\multirow{2}{*}{ t stat } & $-3.96^{* * *}$ & $4.38 * * *$ & 0.87 & -1.04 \\
\hline
\end{tabular}

Jegyzet: ***, **és *az 1\%, 5\% és 10\% szignifikancia szintet jelölik (one-tail test)

Az eredményből, az eredeti felosztásnak megfelelően, az tünik ki, hogy az E2 és E3 típusú események pozitív reakciót váltanak ki, míg az E1 és E4 típusúak negatívat. Viszont az is tisztán kirajzolódik, hogy a tőzsde szelektív a tekintetben, hogy mely erőfeszítéseket jutalmazza, és mely kihágásokat bünteti. A külső forrásból származó értékelésekre adott piaci reakciók, legyenek azok pozitívak vagy negatívak, nem tekinthetők szignifikánsak. A tanulmányokat, rangsorolásokat, és díjakat, melyeket egy harmadik fél bocsát ki (E3) nem méltányolja a piac. Ez az eredmény ellent mond Klassen és McLaughlin 1996-os megállapításának, mely szerint a környezeti díjak híre 0.82\%-os abnormális hozamnövekedést eredményezett. Az eredmények különbözőségének valószínű oka, az időbeli eltérés (részletesebben ld. a longitudinális elemzést), vagyis hogy az utóbbi években az ilyen típusú hírek olyan mértékben elszaporodtak, hogy ez a piac érdektelenségéhez vezetett. Ezzel szemben a belsőleg, a vállalat által kezdeményezett környezet javító tevékenységek (E2) szignifikánsan pozitív hozamokat eredményeztek. Az E2 pozitív hírek átlagosan 1,05 százalékkal növelték a vállalat értékét. A befektetők valószínüleg ezeket a tevékenységeket tekintik értékteremtőknek, mivel a cégeknek ebből származik tényleges monetáris haszna, ellentétben az E3-as típusú eseményekből származó, pusztán reputációs előnyökkel. Azon események, melyek valós pénzbeli következményekkel járnak, az elöírások be nem tartása, perek és büntetések (E1), fontos piaci tényezőknek számítanak. Az E1 negatív hírek átlagban -1,04 százalékkal csökkentették a vállalatok értékét. Míg az egyéb harmadik fél által kezdeményezett leleplező riportok, bojkottok stb. híre (E4) nem tünik jelentős eseménynek a befektetők szemében.

Második lépésben, a vállalatokat külön-külön vizsgáltam. A részletes vállalatonkénti abnormális hozamokat a 11. táblázatban láthatjuk. 
11. táblázat Vállalatonkénti kumulált abnormális hozamok és szignifikancia szintjük

\begin{tabular}{|c|c|c|c|c|}
\hline Vállalat & E1 & E2 & E3 & E4 \\
\hline \multirow{2}{*}{1} & 0.1045 & -0.1536 & 0.2952 & 0.1332 \\
\hline & 0.72 & -0.82 & 1.14 & 0.65 \\
\hline \multirow[b]{2}{*}{2} & -0.3092 & 0.1420 & -0.1702 & 0.0565 \\
\hline & -1.46 & 0.54 & -0.65 & 0.16 \\
\hline \multirow{2}{*}{3} & -0.4089 & 0.9267 & 0.0667 & 0.0855 \\
\hline & $-2.64 * * *$ & $5.26^{* * * *}$ & 0.23 & 0.24 \\
\hline \multirow[b]{2}{*}{4} & -0.4178 & 0.0484 & -0.1082 & 0.0166 \\
\hline & $-2.53 * *$ & 0.35 & -0.72 & 0.05 \\
\hline \multirow{2}{*}{5} & 0.1584 & 0.2424 & 0.1995 & 0.0248 \\
\hline & 0.71 & $1.72 *$ & 1.08 & 0.07 \\
\hline \multirow{2}{*}{6} & -0.1046 & 0.3752 & 0.1841 & 0.5062 \\
\hline & -0.14 & $2.17 * *$ & 0.73 & 0.75 \\
\hline \multirow{2}{*}{7} & -0.4843 & 0.2414 & 0.1377 & 0.1848 \\
\hline & -1.40 & $1.66^{*}$ & 0.87 & 0.70 \\
\hline \multirow{2}{*}{8} & -0.1327 & 0.3188 & 0.0169 & -0.3595 \\
\hline & -0.23 & 0.99 & 0.03 & -0.61 \\
\hline \multirow{2}{*}{9} & -0.0675 & 0.2138 & 0.2784 & -0.4551 \\
\hline & -0.31 & 0.94 & 1.19 & $-1.65 *$ \\
\hline \multirow{2}{*}{10} & -0.1361 & 0.3763 & -0.2322 & \\
\hline & -0.46 & 1.58 & -0.74 & \\
\hline \multirow{2}{*}{11} & -0.8471 & 0.1929 & 0.0239 & \\
\hline & $-2.18^{* *}$ & 0.92 & 0.13 & \\
\hline \multirow{2}{*}{12} & -1.0195 & 0.1350 & -0.0280 & -0.2722 \\
\hline & $-3.27 * * *$ & 0.76 & -0.11 & -1.09 \\
\hline \multirow{2}{*}{13} & -1.6851 & 0.4262 & 0.2580 & -0.0999 \\
\hline & $-2.16 * *$ & 1.33 & 0.60 & -0.18 \\
\hline \multirow{2}{*}{14} & & 0.0681 & -0.0572 & \\
\hline & & 0.23 & -0.22 & \\
\hline \multirow{2}{*}{15} & 0.3950 & 0.8091 & -0.2243 & -0.9625 \\
\hline & 1.02 & 1.38 & -0.39 & -1.56 \\
\hline 16 & -0.1566 & 0.2303 & & \\
\hline \multirow{2}{*}{17} & $-0.2643^{-0.50}$ & 0.0714 & -0.1259 & -0.2049 \\
\hline & -1.06 & 0.09 & -0.51 & -0.67 \\
\hline 18 & & $\begin{array}{r}-0.1216 \\
-0.54\end{array}$ & 0.0566 & $\begin{array}{ll}0.1740 & \\
& 0.48\end{array}$ \\
\hline \multirow{2}{*}{19} & -0.1516 & $0.1090^{-0.07}$ & -0.1303 & -0.0213 \\
\hline & -0.64 & 0.95 & -0.68 & -0.07 \\
\hline \multirow{2}{*}{20} & -0.1826 & 0.0851 & -0.0149 & -0.9697 \\
\hline & -1.08 & 0.78 & -0.08 & $-3.06^{* * * *}$ \\
\hline \multirow{2}{*}{21} & & 0.3756 & 0.2781 & 2.2040 \\
\hline & & 1.18 & 0.57 & 1.40 \\
\hline \multirow{2}{*}{22} & -0.5143 & 0.1116 & -0.0449 & -0.4006 \\
\hline & $-1.73 *$ & 0.82 & -0.22 & -1.34 \\
\hline \multirow{2}{*}{23} & -0.8377 & 0.5048 & 0.0331 & 0.4082 \\
\hline & -1.47 & 1.46 & 0.09 & 0.79 \\
\hline
\end{tabular}

Jegyzet: ***, **és *az 1\%, 5\% és 10\% szignifikancia szintet jelölik (one-tail test) 
Mint a fentiekből kitünik a piaci reakciók korántsem homogének. Habár az aggregált CAR az E1 és E2 típusú eseményekre nagyon meggyőző volt, az individuális vállalatokra tekintve ez nem mindig tükröződik. A huszonhárom vizsgált vállalatból mindössze hat mutatott szignifikánsan negatív eredményeket az E1 eseményekre, és négy szignifikánsan pozitívakat az E2 eseményekre. Viszont találhatunk két szignifikánsan negatív reakciót az E4 típusú hírekre is, amely az összegzett eredményben nem volt látható. Az E3-as típusú események nem generáltak szignifikáns kumulált abnormális hozamot. Némely vállalatnál nincs reprezentálva az összes eseménytípus. Arra is láthatunk némi magyarázatot, hogy az E1 és E2 események miért lettek az összesítésben egyértelmúen pozitívak vagy negatívak, míg az E3 és E4 események nem. Míg a belső eredetü híreknél a CAR előjele majdnem mindig megegyezik, addig a külső jelentések mindössze felénél mozogtak az árak a várt irányba. Erre az érdekes jelenségre a hosszanti elemzés során még visszatérek.

\subsubsection{Vállalati szintü változók szerint}

Miután megállapítottam, hogy a piaci reakció eseménytípusonként eltérő volt, ugyanakkor vállalatonként is változó, a következő lépésben a vállalati mutatók abnormális hozamokra kifejtett hatását vizsgáltam.. A vizsgált időszak 2007 január és 2010 decembere között 556 eseményt foglalt magába. Az események közti eloszlás hasonló volt, mint az egész periódusra (12. táblázat).

12. táblázat A környezeti események megoszlása esemény típus és év szerint (transzverzális elemzés)

\begin{tabular}{lc|cc}
\hline \multicolumn{2}{c|}{ Esemény típus } & \multicolumn{2}{c}{ Év } \\
\hline E1 & 61 & 2010 & 214 \\
E2 & 274 & 2009 & 138 \\
E3 & 173 & 2008 & 118 \\
E4 & 48 & 2007 & 86 \\
\hline
\end{tabular}

A vállalatokat méretük, profitabilitásuk, piaci kockázatosságuk, eladósodásuk, média lefedettségük és környezeti imázsuk szerinti kategóriánként három csoportra osztottam (ld. 6. 
táblázat) és a piaci reakciót minden egyes csoportra a tőzsdei árak pozitív és negatív környezeti hírekre adott válaszaként számítottam ki. Összesen 18 regressziós egyenletet futtattam le, amelyek eredményei a 13. táblázatban találhatóak:

13. táblázat $\mathrm{A}$ vállalati szintủ változók hatása az abnormális hozamokra

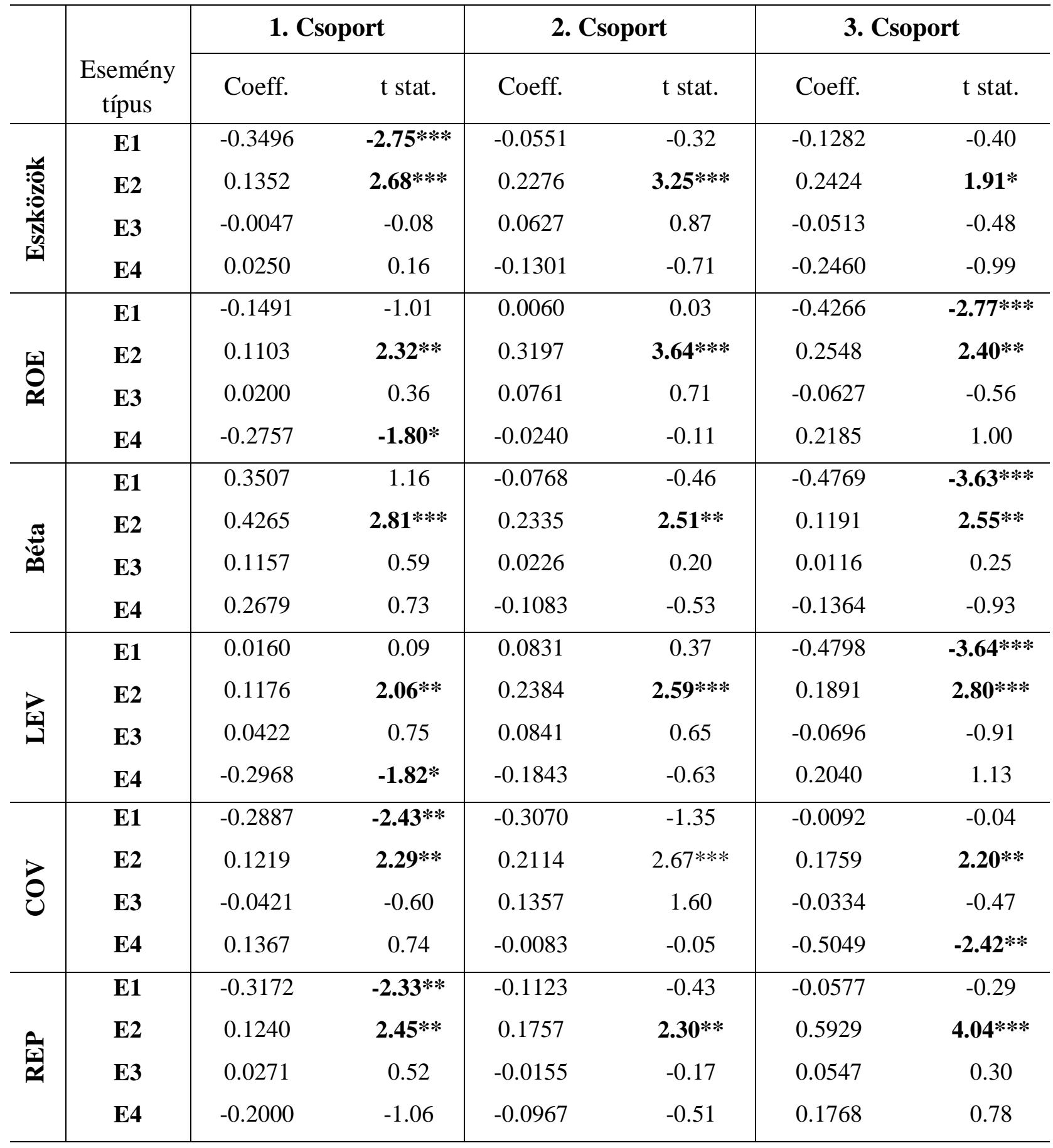

Jegyzet: ***, **és * az 1\%, 5\% és 10\% szignifikancia szintet jelölik (one-tail test) 


\subsubsection{A pénzügyi változók elemzése}

Hasonlóan az eseménytípusra végzett vizsgálatokhoz, itt is elsősorban az E1 és E2-es (belső) események produkáltak értékelhető (szignifikáns) eredményeket, míg a harmadik féltől származó E3-as egyáltalán nem és az E4-es is csak két alkalommal. A pénzügyi változókon belül a méret és profitabilitás illetve a piaci kockázat és adóság állomány együtt mozognak, így e tényezők elemzését csoportosítva külön-külön mutatom be.

\section{Méret és profitabilitás:}

$\mathrm{Az}$ 1. csoport mind méretét mind profitabilitását tekintve stabilabb vállalatokat tartalmaz, míg a 3. csoport a kisebb, kevésbé jövedelmező cégeket. A pozitív belső események (E2) szignifikáns pozitív reakciókat váltottak ki a tőzsdei árakban, mindhárom csoportban. Az abnormális hozamok méretüket tekintve magasabbak a kisebb cégeknél (0,25 körül) mind a nagyobbaknál (0,11 és 0,13 között), azt mutatva, hogy a piac a kisebb, kevésbé profitábilis vállalatokat nagyobb mértékben jutalmazza pozitív környezetvédelmi tevékenységükért. A pozitív külső események (E3) nincsenek hatással a vállalatok tőzsdei áraira. A kedvezőtlen belső események (E1), mint a környezetvédelmi bírságok és egyéb büntetések, szignifikánsan negatív hatással vannak a nagyobb illetve a kevésbé jövedelmező cégek áraira. Az első eredmény talán meglepőnek tünik, de nem akkor, ha a piac dinamikáját is figyelembe vesszük. Mivel a prominens nagyvállalatok sokkal inkább a figyelem középpontjában állnak, ezért több és lényegesen jelentősebb büntetéssel kell szembe nézniük és mindemellett a befektetők és elemzők is nagyobb figyelmet szentelnek nekik. Míg az egyébként is rossz anyagi helyzetben lévő vállalatok kevésbé tudják a környezetvédelmi büntetések plusz pénzügyi terhét feldolgozni. Hasonlóan a pozitív külső eseményekhez a negatív külső események (E4) sem produkálnak szignifikáns piaci reakciókat, kivéve a magas ROE-jü cégeknél ahol -0,28\%-os értékcsökkenést tapasztalunk.

Piaci kockázat és adóság állomány:

A béta és adósság pénzügyi faktorok esetében az egyes kategória kockázatosabb és több hosszútávú adóssággal rendelkező vállalatot tartalmaz, míg a harmadik kategória a kevésbé 
kockázatos és eladósodott vállalatokat. A bétára kapott eredmények egyértelmüek. Minél volatibilisebb, instabilabb a cég annál nagyobb a pozitív környezeti tevékenységböl (E2) származó nyereség. Az abnormális hozam az első kategóriás vállalatoknál átlagban 0,43, a második kategóriásoknál 0,23, míg a harmadik kategóriásoknál csak 0,12. Az adósság ráta esetében is növelik a cégértéket a pozitív kezdeményezések, de itt a tendencia pont fordított, vagyis a legmagasabb plusz hozamot az alacsony adósságállományú cégek könyvelhetik el, míg a legalacsonyabbat a magas adósságállományúak. Ez a tendencia logikusnak mondható, mivel a legtöbb pozitív környezeti kezdeményezés általában extra kiadásokkal is jár, és a befektetők nem feltétlenül tekintik ezt ésszerünek a már amúgy is eladósodott vállalatok esetében. A külső forrásból származó kedvező hírekre (E3) itt sem reagál a piac. A belső tevékenységből eredő negatív események (E1) csak a jó állapotban lévő vállalatok, vagyis alacsony béta és LEV, esetében eredményeztek szignifikánsan negatív abnormális hozamokat (0,48 körül). A befektetők itt egyértelmüen büntetik a jobb helyzetben lévő vállalatokat, mivel ezek a negatív események nyilvánvalóan csökkentik jövőbeli elvárásaikat ezekkel a vállalatokkal szemben. Külső szemlélők által kinyilvánított negatív hírek (E4) csak a magas adósság rátájú cégek esetében hoznak negatív abnormális hozamokat.

Az eredmények azt mutatják, hogy a piaci reakciók változnak a pénzügyi mutatók függvényében. A kedvező környezeti hírek a kisebb, kevésbé profitabilisebb cégek esetében hozzák a legtöbb hasznot. A kockázatosabbnak vélt vállalatok is jobban profitálnak az ilyen kezdeményezésekből. A legkevésbé a magas hosszútávú adósságrátával rendelkező cégek „zöld” cselekedeteit értékeli a piac. A szennyező termelési technikából eredő büntetések pedig leginkább a nagyméretủ illetve az alacsony profitabilitású cégeket sújtják, illetve azokat, melyeket a piac alacsony kockázatúnak (béta és LEV) ítél meg.

\subsubsection{A nem pénzügyi változók elemzése}

A két nem pénzügyi mutató, média lefedettség és környezeti imázs, esetében az E2-es (pozitív belső) események mindhárom kategóriában növelik a cégértéket. A hatás nagyobb azoknál a cégeknél, amelyekkel a sajtó kevesebbet foglalkozik. Szintén jobban profitálnak a pozitív kezdeményezéseikből a kevésbé jó hírnévnek örvendö vállalatok. Ellenben, a külső forrásból eredő pozitív megnyilatkozások (E3) itt sem eredményeznek szignifikáns reakciókat. 
Megállapítható tehát, hogy minél jobb egy vállalat reputációja, és minél többet szerepel a sajtóban, annál kisebb pénzügyi haszna származik a pozitív kezdeményezéseiböl. Ez könnyen összeegyeztethető a hatékony piac hipotézisével, mely szerint, ha egy eseményt a piac előre lát, akkor annak hatása már eleve beépül a cég piaci árába. Ennek megfelelően, azon vállalatok esetében, melyek magas média lefedettséggel és jó imázzsal rendelkeznek, a negatív (E1) események nagyobb áresést eredményeznek (átlagban 0,30\%-kal), mivel a befektetők ilyenkor jobban „meglepődnek”, vagyis a piac egy elöre nem várt eseményre reagál. A média által kevésbé szem előtt lévő vállalatoknál tapasztalhatunk egyedül drámai értékpapír árcsökkenést (0,50\%-kal) külső megítélők negatív híreire (E4). Talán az a tény, hogy ezen vállalatok alig szerepelnek a hírekben, és amikor igen akkor is negatív elöjellel, hevesebb piaci reakciót vált ki.

Egy érdekes, elöre nem várt megállapítás, hogy habár a külső megítélők véleményei önmagukban közvetlenül nem befolyásoljak a vállalatok tőzsdei árait, közvetve igenis hatással vannak egy cég általános környezeti imázsának kialakítására, és mint láttuk a környezeti imázs befolyásolja a vállalat belső tevékenységéből származó hírekre adott tőzsdei reakciókat

Az eredmények tehát azt mutatják, hogy mindkét nem pénzügyi változó befolyásolja a belső események híreire adott reakciókat. A kedvező környezeti megítélés csökkenti a pozitív, míg növeli a negatív hírekre adott reakciókat. A média lefedettség esetében az eredmények nem ennyire egyértelmüek. Úgy tünik, hogy a hír előjele és jellege is befolyásolja, hogy a média figyelme növeli, vagy csökkenti a reakciókat. Belső eseményeknél a nagyobb média lefedettség tompítja a pozitív, míg erősíti a negatív hírek hatását. A külső negatív hírek esetében azonban a kisebb figyelem az, ami nagyobb reakcióhoz vezet.

\subsection{Longitudinális elemzés}

Következő kutatási témaköröm a környezeti hírekre adott piaci reakciónak időbeli változásait taglalja. Az elemzés részeként először trendanalízis segítségével a hírek típus szerinti alakulását vizsgáltam. Második lépésben a négy eseménytípusra létrehozott portfolió abnormális hozamainak változását elemeztem, hogy ezek segítségével meghatározhassam a megfelelö törésvonalakat, amelyek mentén az eseményeket csoportosíthatom. Legvégül pedig az így elkülönített időszakaszok különbözőségét az átlagos kumulált abnormális hozamok mediánjának elemzésével ellenőriztem. 


\subsubsection{Trendanalízis}

Az eseménytípusok között, első rátekintésre is, megfigyelhető egy nyilvánvaló különbség (13 ábra). Amíg a negatív jellegü hírek száma a kezdeti enyhe emelkedő trend után kiegyenlítődött, addig a pozitív sajtóhírek exponenciálisan megugrottak. A pozitív hírek számának megugrását a 2005-ös év első harmadától figyelhetjük meg (Kyoto protokoll érvénybe lépése: 2005 február 16). A külső forrásokból származó hírek, mind pozitív mind negatív oldalról, csak a 1999-es év után tűntek fel állandó jelleggel az írott médiában. Azonban, amíg a környezetvédelmi besorolások, listák és díjak folyamatosan emelkedő trendet mutatnak, addig a kedvezőtlen riportok száma a kezdeti ugrás után ellaposodott. Ez két pontosan kivehető tendenciát tükröz: először is a vállalatok felismerték a média szerepének fontosságát és nagyobb figyelmet szentelnek környezeti imázsuk menedzselésének, másodszor pedig a közhasznú szervezetek és befektetői közösségek egyre aktívabbá váltak a vállalatok társadalmi felelősségének, és ezen belül környezeti tevékenységének nyomon követésében.

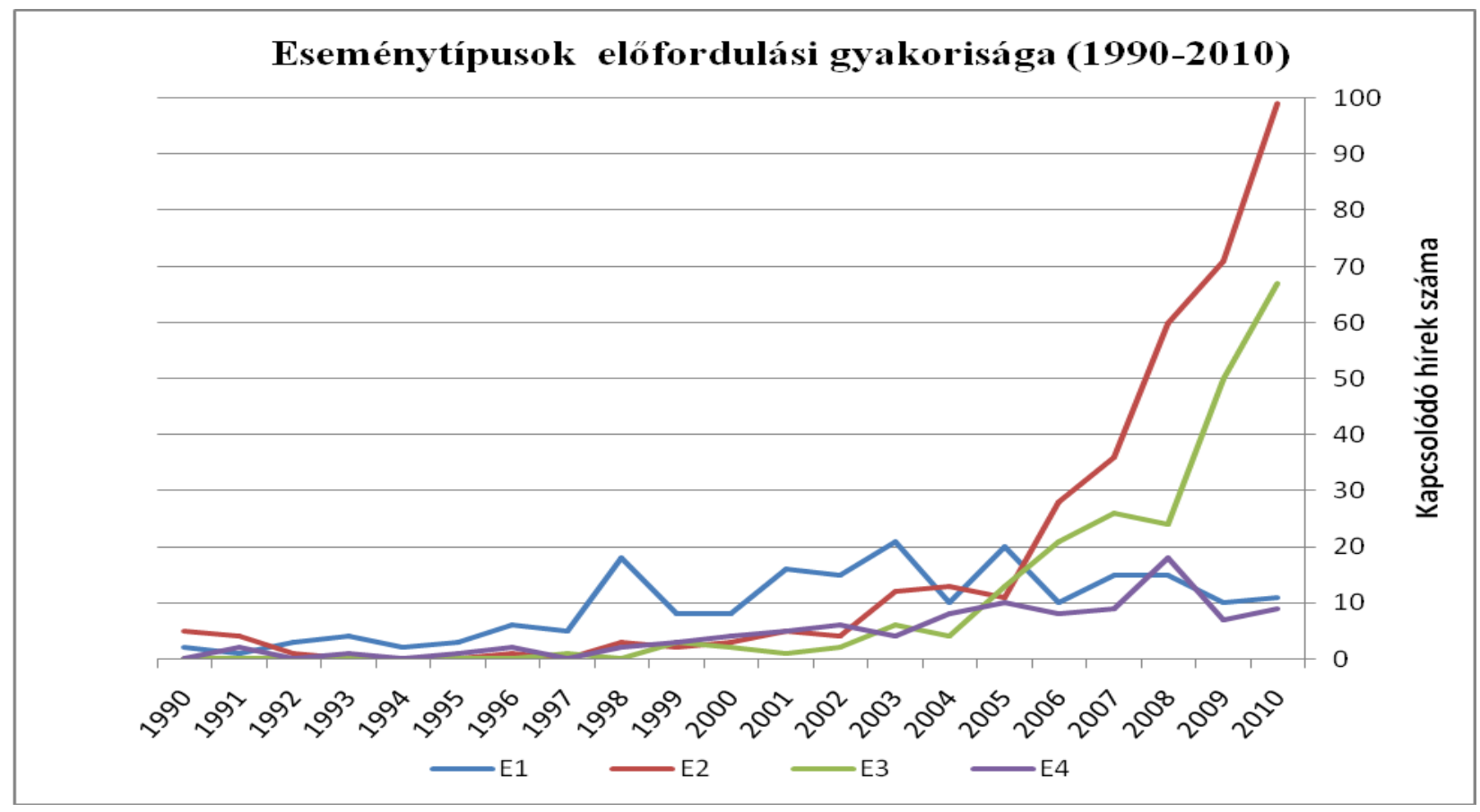

13. ábra Eseménytípusok gyakoriságának alakulása a nyomtatott médiában 1990-2010 között

Az elemzéshez első lépésben a három napos kumulált abnormális hozamokat, illetve ezeknek az átlagtól való abszolút eltérését egy egyszerü scatter graph (szórás diagramm) segítségével elemeztem (14-17 ábrák). 


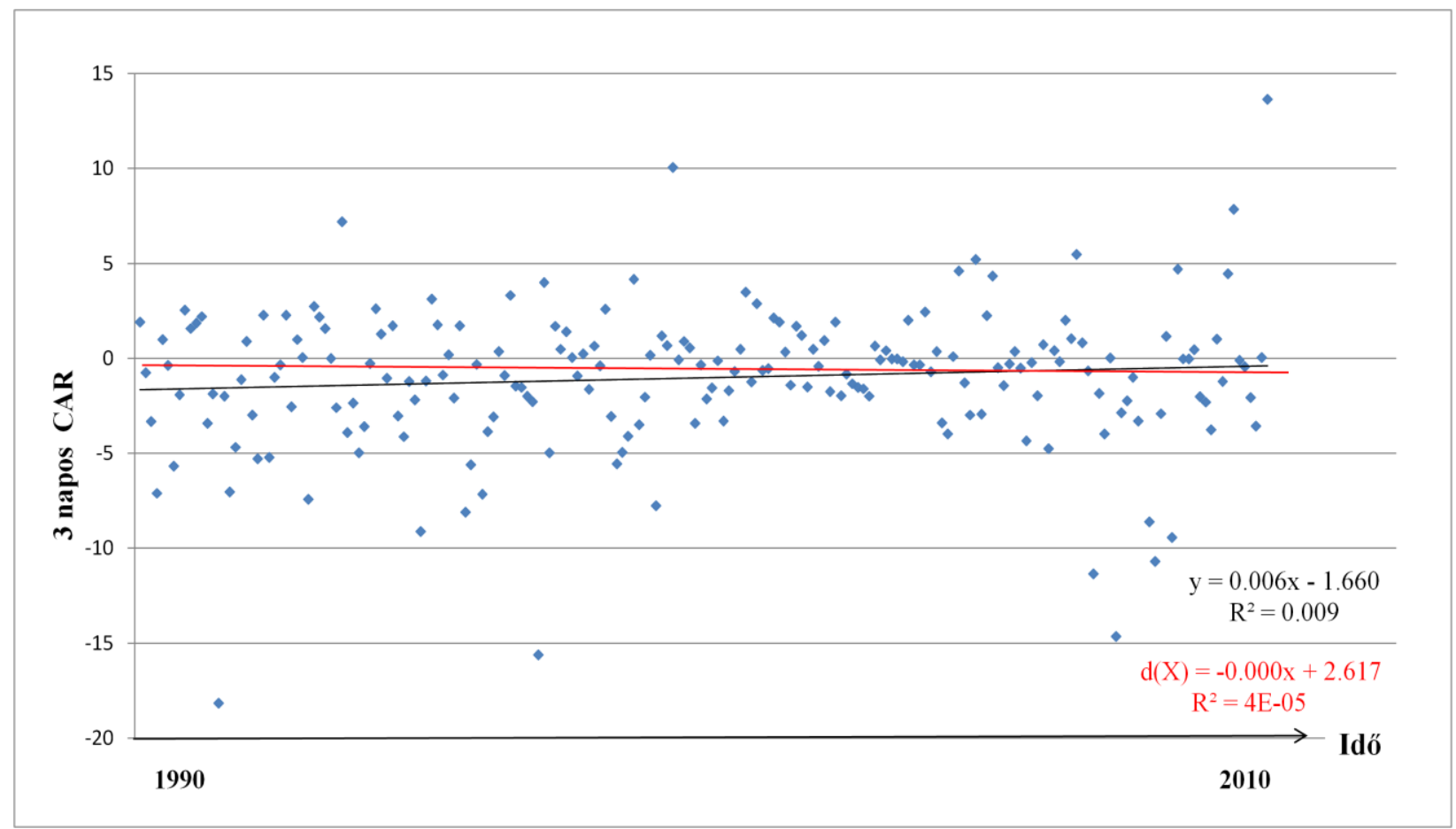

14. ábra E1 típusú események három napos abnormális hozamainak és átlagos abszolút eltérésének lineáris trendgörbéje

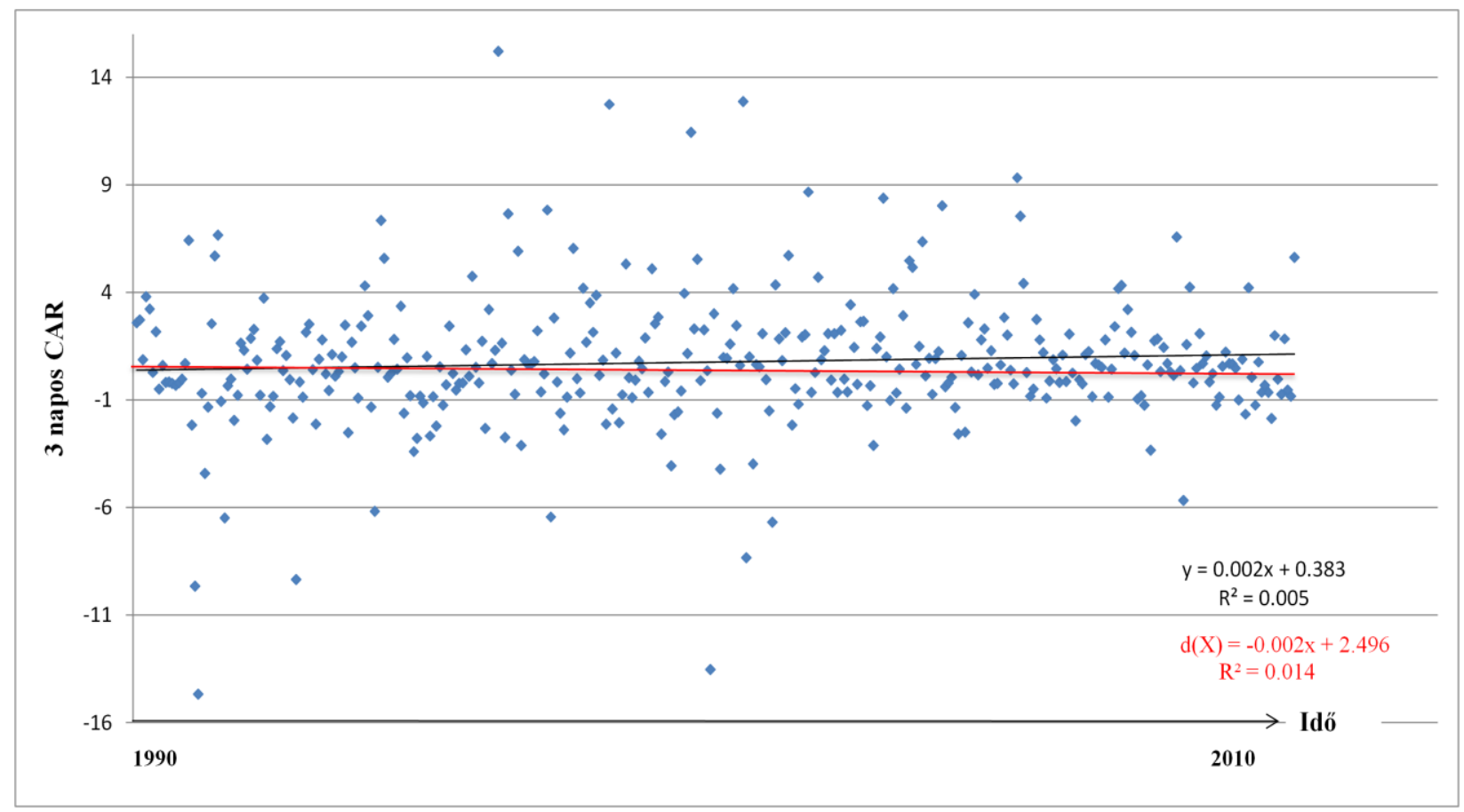

15. ábra E2 típusú események három napos abnormális hozamainak és átlagos abszolút eltérésének lineáris trendgörbéje 


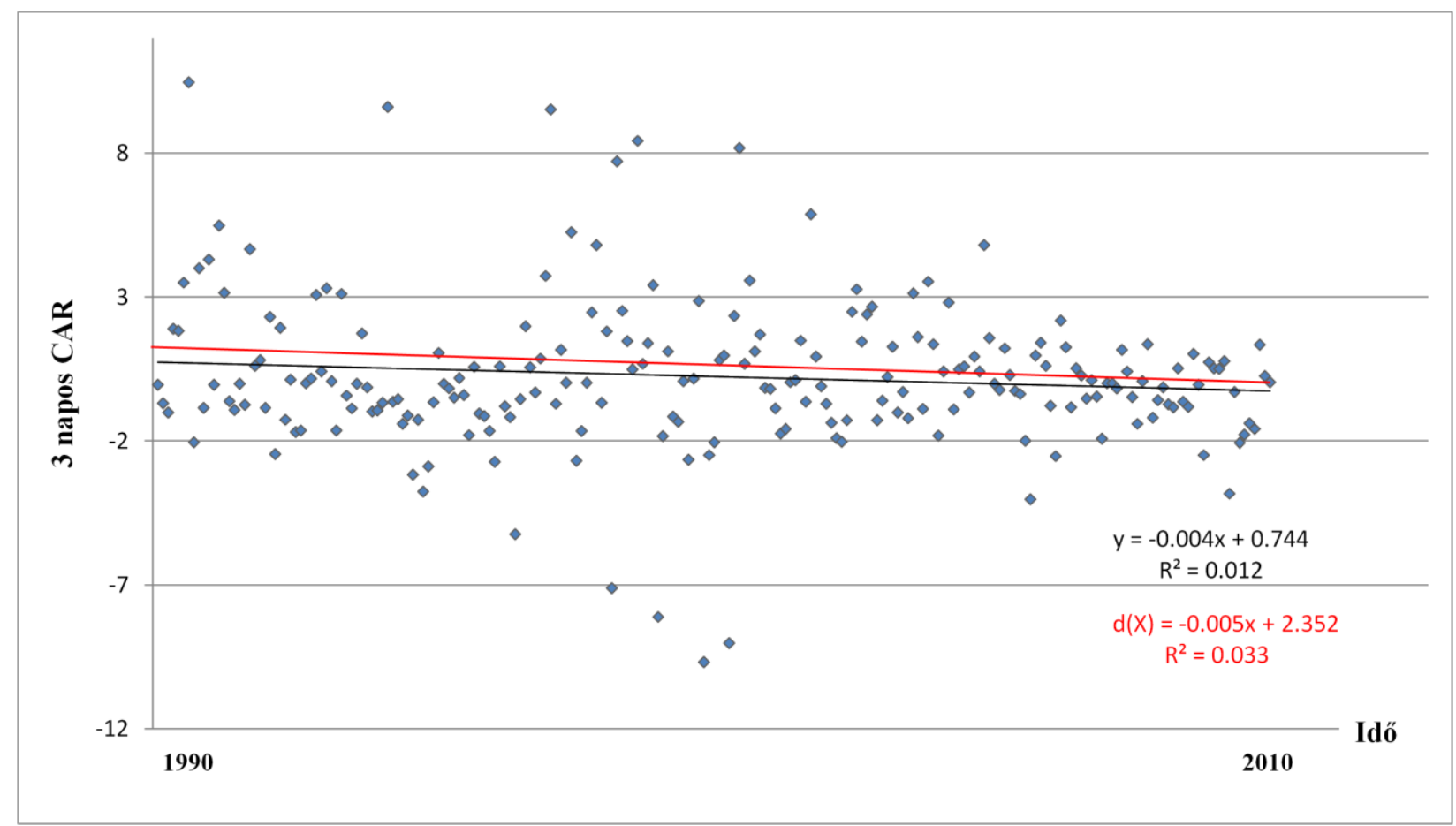

16. ábra E3 típusú események három napos abnormális hozamainak és átlagos abszolút eltérésének lineáris trendgörbéje

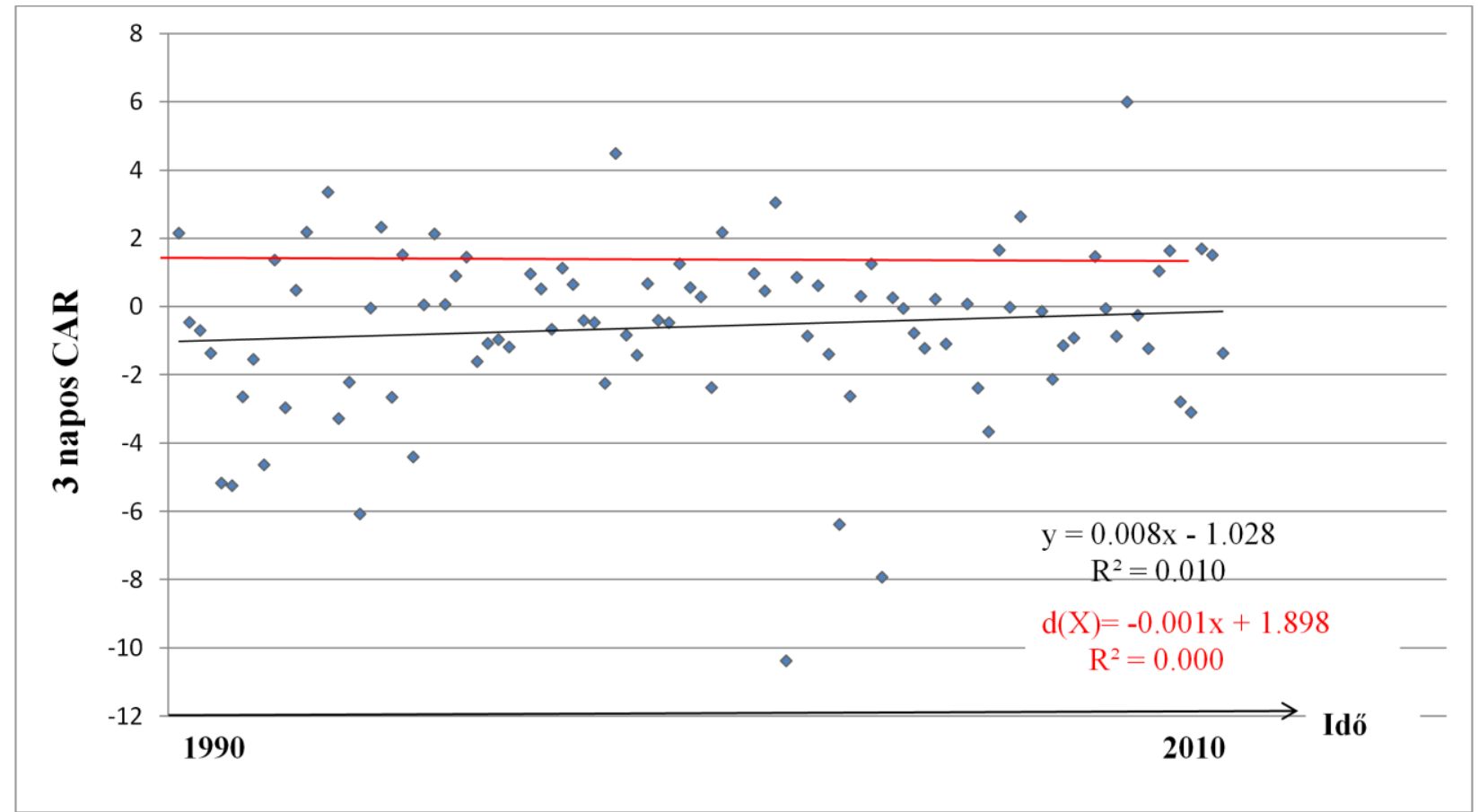

17. ábra E4 típusú események három napos abnormális hozamainak és átlagos abszolút eltérésének lineáris trendgörbéje 
Az elmúlt két évtized sajtóanyagának áttekintésekor a vállalatok pozitív környezeti imázs felépítésére tett erőfeszítéseinek növekedését figyelhetjük meg. A vállalatok által kezdeményezett a környezeti teljesítmény illetve a környezeti megítélés javítására irányuló intézkedések esetében (E2-es eseménytípus) ez az erőfeszítés, mint azt a keresztmetszeti elemzés során is láthattuk, anyagi szempontból is kifizetődő. A scatter graph-ból viszont az is kitünik, hogy a CAR-ok ezen túl egy enyhe pozitív tendenciát is mutatnak (+0,02\%). Tehát, nem csak hogy értékeli a piac ezeket az eseményeket, de nagyobb hangsúlyt is helyez rájuk. A két negatív eseménytípus esetében azonban a CAR-ok szintén pozitív tendenciájúak (E1 0,06\% és E4 0,08\%), vagyis a piac ez esetben az idő előrehaladtával egyre kisebb mértékben bünteti a vállalatokat. A külső rangsorolások és díjak megítélésénél pedig úgy tünik, hogy ezek a riportok vesztettek népszerüségükből, mivel itt a CAR-ok -0,4\%-kal csökkenő tendenciát mutatnak, vagyis a piac ezeket a híreket kedvezőtlenebbül árazza be. Ez valószínüleg az SRI piac beérését is tükrözi, ahol az elmúlt években jelentős konszolidáció történt az alapkezelő vállalatok között, amely ezzel egy időben a standardizálására irányuló törekvésekkel is párosult. Az események szóródásában is megfigyelhetünk eltéréseket. Habár az átlagtól való abszolút eltérés, d (X), mind a négy esettípusnál csökkenő tendenciát mutat, a két pozitív típusú esemény (E2 és E3) szórása egyértelmüen nagyobb mértékben csökkent (-0,02\% és -0,05\%) míg a két negatív típusúe (E1 és E4) lényegében változatlan maradt (-0,00\% és -0,01\%). Itt is az E3-as külső megítéléseknél és riportoknál figyelhetjük meg a legnagyobb rendeződést, míg a külső forrásból származó negatív eseményeket változatlanul széles skálán értékeli a piac.

\subsubsection{A populációk sztochasztikus ugyanakkoriságának vizsgálata}

A további mélyrehatóbb hosszanti elemzéshez az esemény típusok szerinti portfoliók elmúlt húsz éves kumulált abnormális hozamát grafikusan ábrázoltam (ld. 18-21 ábrák). Az ábrák segítségével láthatóvá váltak a különböző trendek, és törésvonalak, így megfelelő időintervallumokra lehetett bontani minden egyes eseménytípust, hogy azokat összehasonlíthassam. Míg az így létrehozott portfoliókban az összes eseménytípusnál a hozamok a várt irányba mozogtak, addig az E1 és E2-es események láthatóan homogénebbek, míg az E3 és E4-esek ciklikusabbak voltak. Ez is egyik magyarázata annak, hogy az E3, és E4 típusú eseményeknél az átlagos kumulált CAR nem volt szignifikáns a keresztmetszeti elemzés során. A fentieknek megfelelően az egymástól elkülöníthető időszakaszok száma is 
eseménytípusonként változó. Az E2-es események esetében mindössze két eltérő szakasz állapítható meg, míg az E3-as események esetében már hat. Természetesen, minden esetben az események további differenciálása is lehetséges (extrém esetben akár napi bontásban is), de ez ellentétes lenne az elemzés céljával, vagyis az általános trendek feltárásával illetve a szignifikáns eltérések felfedezésével. Sok esetben, a rövidebb intervallumokra bontás nem is hozott magasabb szignifikancia vagy plusz információ értékủ eredményeket.

Általánosan megállapítható, hogy néhány érdekes kivételtől eltekintve, az egyes eseménytípusokra jellemző törésvonalak nem ugyanazon időpontokra esnek. Ilyen érdekes egybeesés például 2007 áprilisa, amikor két fontos esemény, az Egyesült Államok legfelsőbb bíróságának egy irányadó döntése, illetve az IPPC (Intergovernmental Panel on Climate Change) klíma jelentése, pozitív irányba mozdította el a közvélemény hozzáállását a környezetvédelemmel kapcsolatban. Ennek megfelelöen az E2-es típusú események CAR-jánál egy felfelé ívelö tendenciát, míg az E4 és E1-es eseményeknél ennek az ellenkezőjét, a CAR-ök negatív irányú elmozdulását figyelhetjük meg. A kormányzati politika változásai, mint például George Bush klíma tervének bejelentése 2003 februárjában, vagy Obama elnökké választásának híre 2008 novemberében, szintén fontos, a befektetők viselkedését befolyásoló, és az idősíkon tisztán kimutatható tényezők voltak.

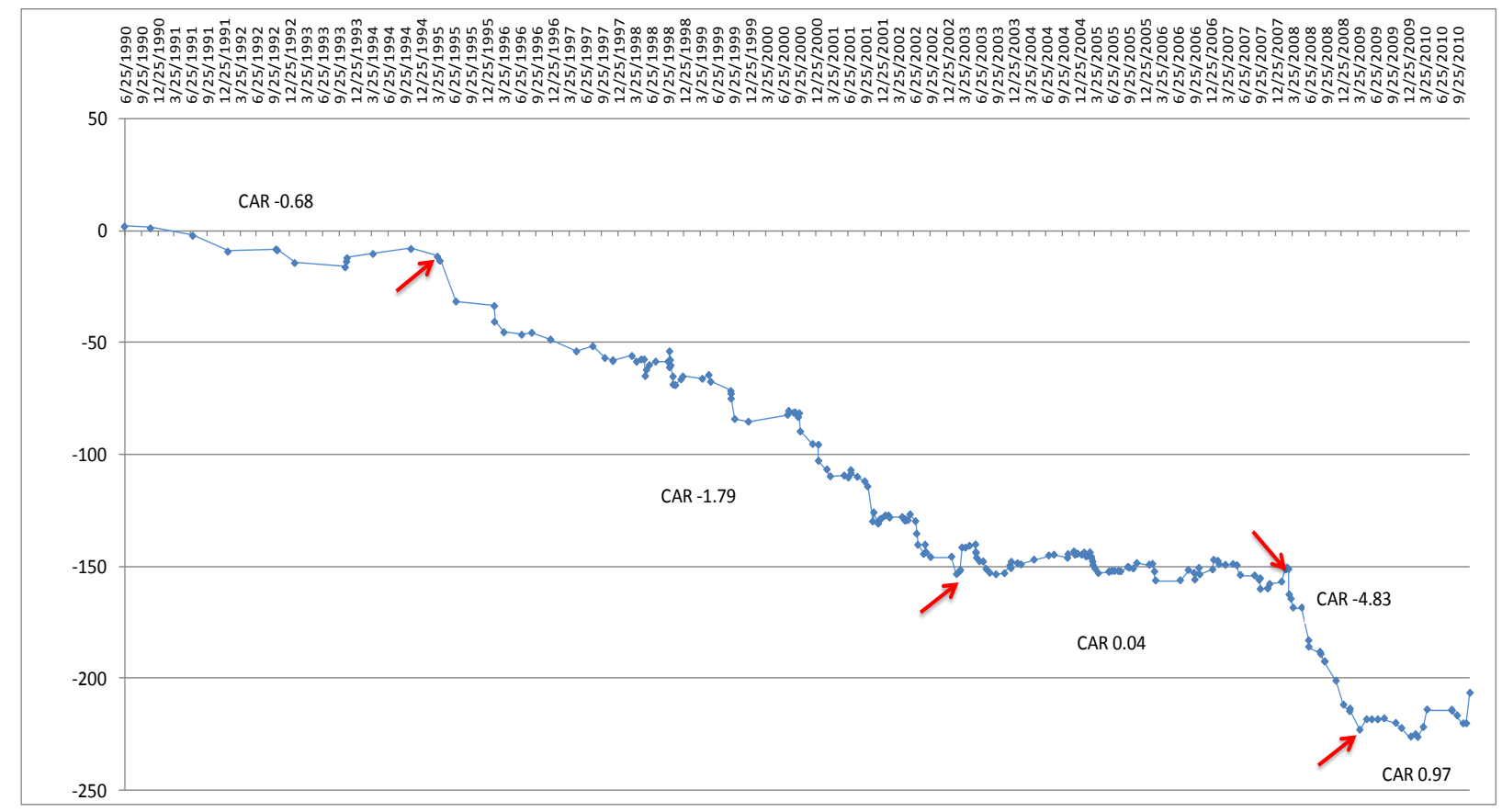

18.ábra E1 portfolió: negatív belső események kumulált átlagos három napos abnormális hozamának alakulása 


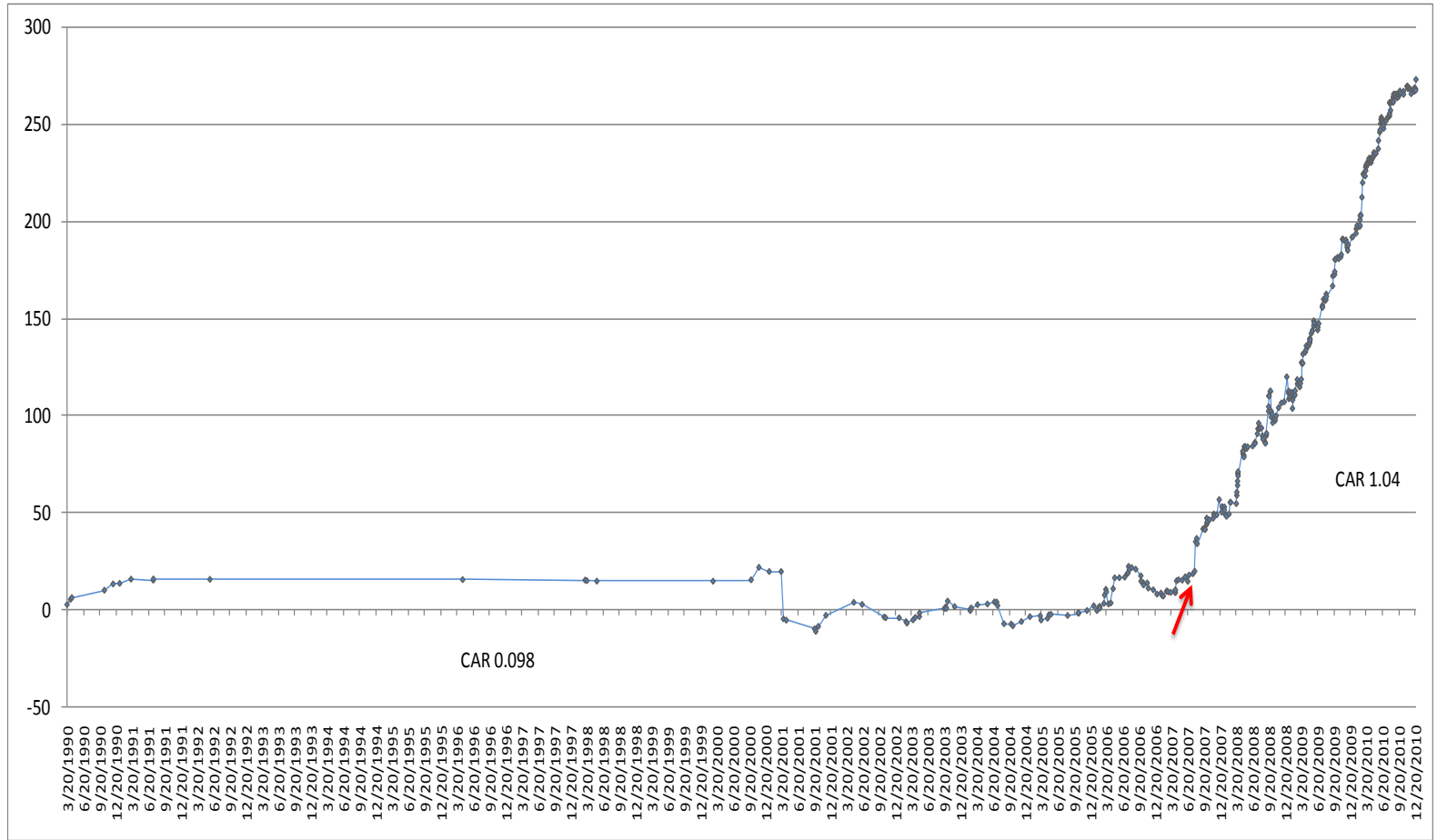

19. ábra E2 portfolió: pozitív belső események kumulált átlagos három napos abnormális hozamának alakulása

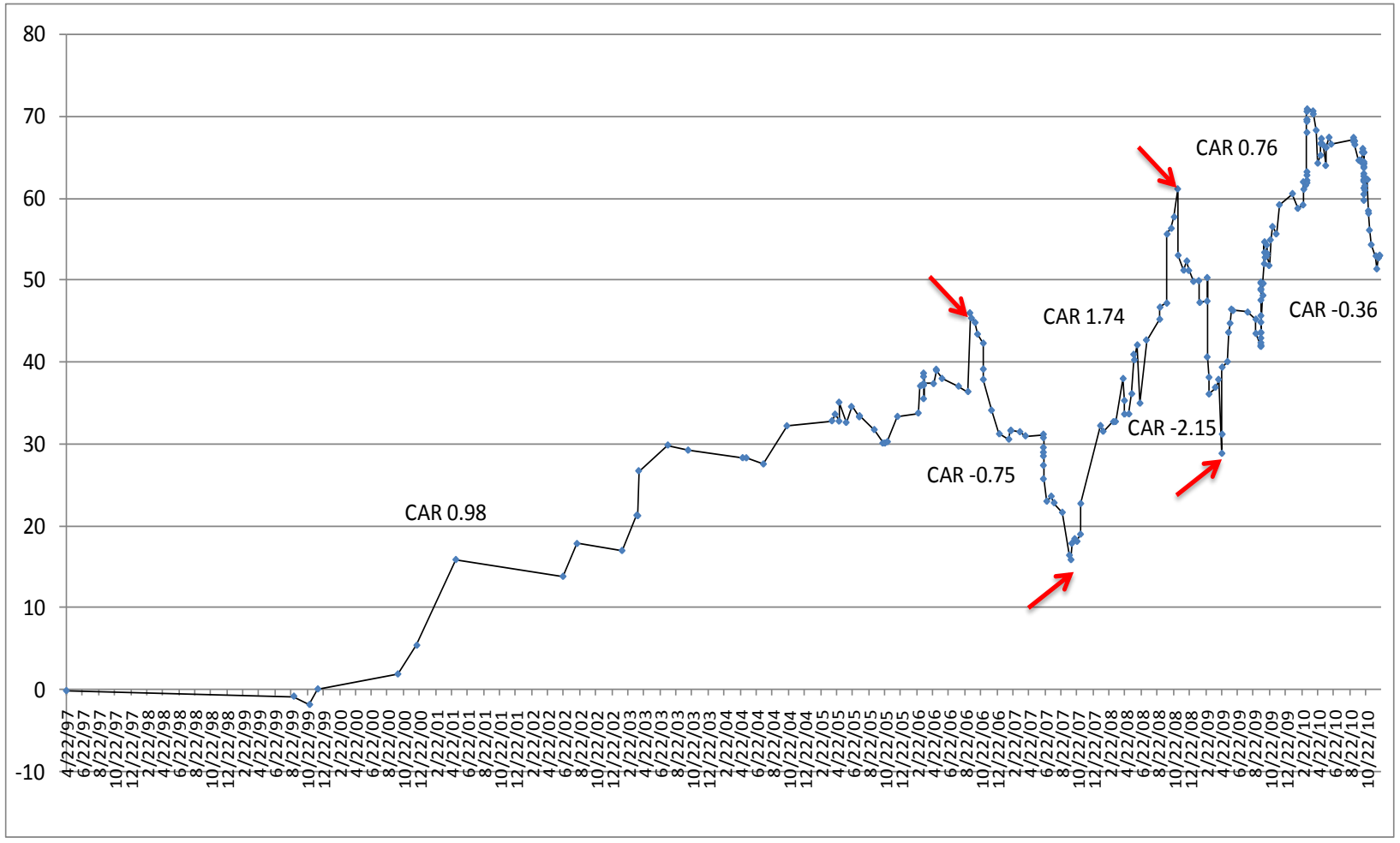

20. ábra E3 portfolió: pozitív külső események kumulált átlagos három napos abnormális hozamának alakulása 


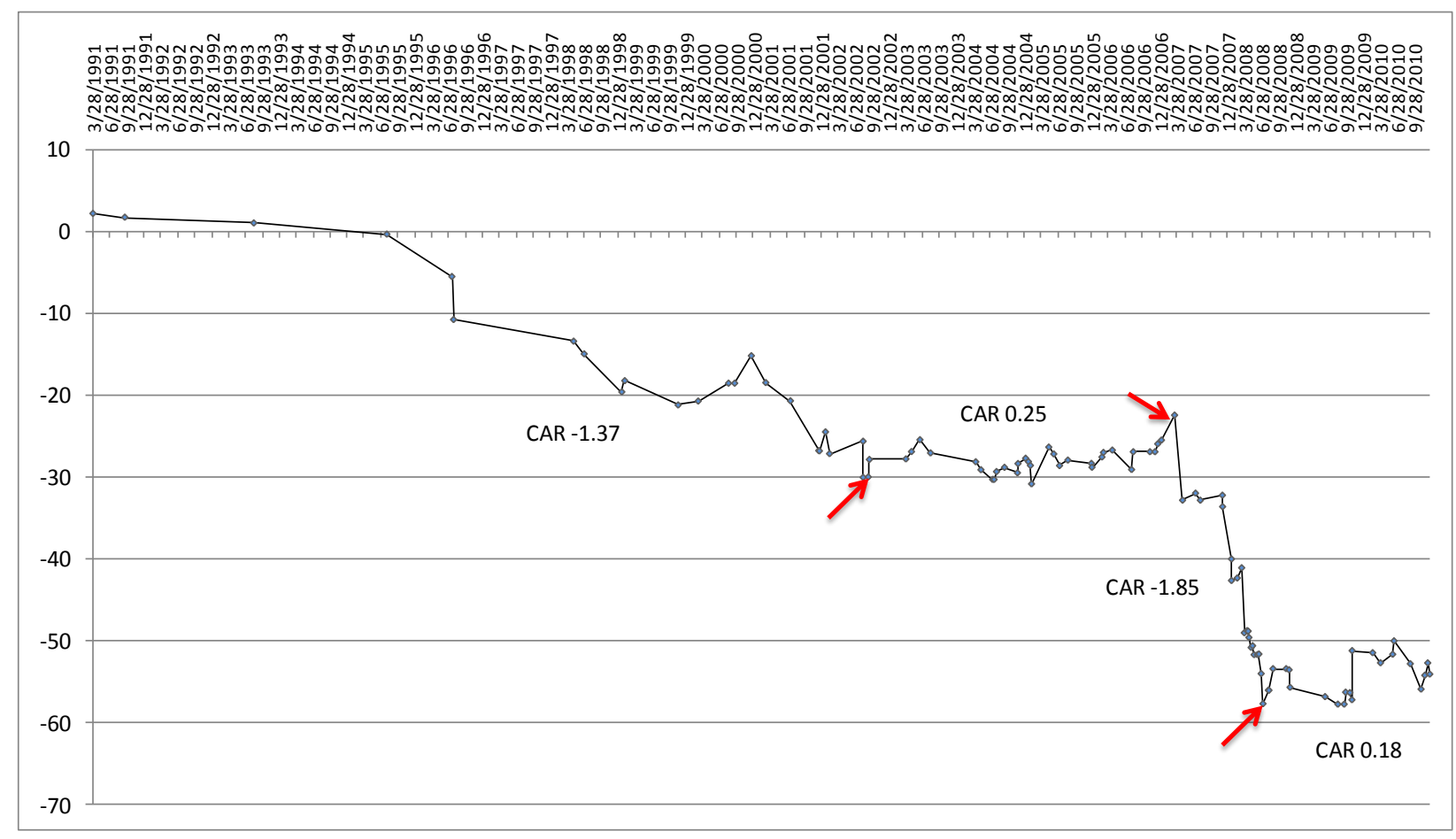

21. ábra E4 portfolió: negatív külső események kumulált átlagos háromnapos abnormális hozamának alakulása

Mint a fentiekből is kitünik a grafikus ábrázolás több szempontból is szükségszerü volt. Először is, így az összehasonlítandó periódusok nem valami tetszőleges dátum mentén, hanem jól kirajzolódó törésvonalak mentén alakíthatóak ki. Másodszor pedig nyilvánvalóvá vált, hogy az eseménytípusokra nem lehet egy sablont ráhúzni, hanem mindegyiket külön kell vizsgálni. A négy portfolió íly módon felosztott időperiódusaiba eső eseményeinek átlagos és medián három napos kumulált abnormális hozamait a 14-as táblázatban láthatjuk.

14. táblázat Az E1-E4 események kiválasztott időintervallumainak átlagos és medián három napos kumulált abnormális hozamai

\begin{tabular}{ll|cccccc}
\hline & & 1. periódus & 2. periódus & 3. periódus & 4. periódus & 5. periódus & 6. periódus \\
\hline \multirow{2}{*}{ E1 } & medián & 0.2978 & -1.2279 & -0.1466 & -2.9079 & -0.0297 & \\
& átlag & -0.6772 & -1.7931 & 0.0382 & -4.8295 & 0.9708 & \\
\multirow{2}{*}{ E2 } & medián & 0.2076 & 0.6602 & & & & \\
& átlag & 0.0981 & 1.0379 & & & & \\
\multirow{2}{*}{ E3 } & medián & 0.1004 & -0.7959 & 1.2802 & -1.3378 & 0.4157 & -0.2089 \\
& átlag & 0.9795 & -0.7497 & 1.7411 & -2.1525 & 0.7645 & -0.3573 \\
E4 & medián & -1.4561 & 0.2849 & -0.8625 & -0.0989 & & \\
& átlag & -1.3660 & 0.2450 & -1.8532 & 0.1804 & & \\
\hline
\end{tabular}


A továbbiakban ellenőriztem, hogy az így létrehozott csoportjaim jól definiáltak-e, vagyis először egy Kruskal-Wallis tesztet futtattam, majd a post-hoc analízishez elvégeztem az egyes időintervallumokba eső CAR-ok mediánjainak páronkénti összehasonlítását. A Mann-Whitney teszt eredményei (Bonferroni korrigált változatban is) a 15-es táblázatban láthatóak:

15. táblázat A Mann-Whitney post-hoc teszt eredményei (Bonferroni korrigált/korrigálatlan) a négy eseménytípus kiválasztott időintervallumaira

\begin{tabular}{|c|c|c|c|c|c|}
\hline \multicolumn{6}{|c|}{ E1 Típusu Események } \\
\hline $\mathbf{H}$ & 21.24 & & & & \\
\hline \multirow[t]{3}{*}{$\mathbf{p}$} & 0.000283 & & & & \\
\hline & 1. periódus & 2. periódus & 3. periódus & 4. periódus & 5. periódus \\
\hline & $11 / 2 / 1994$ & $2 / 18 / 2003$ & $2 / 28 / 2008$ & $4 / 6 / 2009$ & $12 / 31 / 2010$ \\
\hline $11 / 2 / 1994$ & & 0.2688 & 0.9757 & 0.01572 & 0.8421 \\
\hline $2 / 18 / 2003$ & 1 & & 0.002596 & 0.02318 & 0.07465 \\
\hline $2 / 28 / 2008$ & 1 & 0.02596 & & 0.000065 & 0.9327 \\
\hline $4 / 6 / 2009$ & 0.1572 & 0.2318 & 0.0006465 & & 0.003224 \\
\hline $12 / 31 / 2010$ & 1 & 0.7465 & 1 & 0.03224 & \\
\hline
\end{tabular}

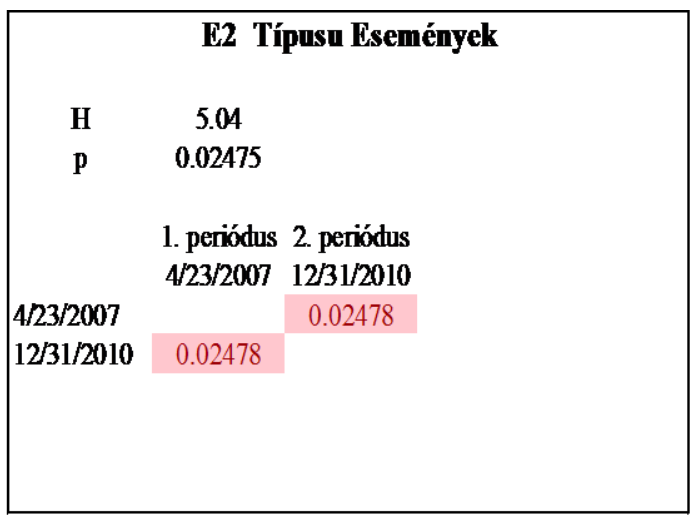

\begin{tabular}{|c|c|c|c|c|c|c|}
\hline \multicolumn{7}{|c|}{ E3 Típusu Események } \\
\hline $\mathbf{H}$ & 32.54 & & & & & \\
\hline \multirow[t]{3}{*}{$\mathbf{p}$} & $4.639 \mathrm{E}-06$ & & & & & \\
\hline & 1. periódus & 2. periódus & 3. periódus & 4. periódus & 5. periódus & 6. periódus \\
\hline & $5 / 8 / 2006$ & $10 / 2 / 2007$ & $11 / 10 / 2008$ & $4 / 27 / 2009$ & $3 / 17 / 2010$ & $12 / 31 / 2010$ \\
\hline $5 / 8 / 2006$ & & 0.00124 & 0.1583 & 0.00886 & 0.913 & 0.04802 \\
\hline $10 / 2 / 2007$ & 0.01865 & & $6.85 \mathrm{E}-05$ & 0.5739 & 1.64E-04 & 0.0264 \\
\hline $11 / 10 / 2008$ & 1 & 0.00103 & & 0.00278 & 0.09813 & 0.00047 \\
\hline $4 / 27 / 2009$ & 0.1329 & 1 & 0.04173 & & 0.00481 & 0.1543 \\
\hline $3 / 17 / 2010$ & 1 & 0.00246 & 1 & 0.07211 & & 0.00945 \\
\hline $12 / 31 / 2010$ & 0.7203 & 0.396 & 0.007026 & 1 & 0.1418 & \\
\hline
\end{tabular}

\begin{tabular}{|ccccc|}
\hline \multicolumn{5}{|c|}{ E4 Típusu Események } \\
H & 9.87 & & \\
p & 0.01970 & & & \\
& & & & \\
& 1. periódus & 2. periódus & 3. periódus & 4. periódus \\
& $8 / 13 / 2002$ & $3 / 21 / 2007$ & $7 / 10 / 2008$ & $12 / 31 / 2010$ \\
$7 / 20 / 2004$ & & 0.01698 & 0.9137 & 0.0520 \\
$3 / 21 / 2007$ & 0.1019 & & 0.01114 & 0.8546 \\
$7 / 10 / 2008$ & 1 & 0.06683 & & 0.09456 \\
$12 / 31 / 2010$ & 0.312 & 1 & 0.5674 & \\
& \multicolumn{4}{c}{} \\
\end{tabular}

A Kruskal-Wallis teszt alapján a csoportosítás mind a négy eseménytípusra releváns volt $(\mathrm{p}<0,05)$. A páronkénti eltérések az E4-es események kivételével a bonferroni korrekció után is majdnem minden esetben szignifikánsak maradtak, tehát a kiválasztott időintervallumok egymástól különbözőnek mondhatóak. 


\subsection{Hipotézisek verifikálása}

$\mathrm{H}_{1}$ : A piac nem reagál minden környezeti hírre egyformán: Várható, hogy a piac bizonyos hírcsoportokra egyáltalán nem reagál, mivel azokat nem tekinti értékteremtőnek vagy rombolónak.

Az eredmények megerősítik az eddigi kutatásokat, hogy a tôzsdei árak pozitív környezetvédelmi események hírére emelkednek, míg környezeti kihágások hírére csökkenek. Ezen túl megállapítható, hogy azon események, amelyek direkt, belső vállalati tevékenység következményei (pozitív vagy negatív) szignifikánsan befolyásolják a tőzsdei árakat, míg harmadik félhez kötődő külső vélemények és megnyilvánulások nem.

$\mathrm{H}_{2}$ : Különböző vállalati szintü pénzügyi jellemzök, mint méret, profitabilitás, vagy kockázat, befolyásolják a piac reakcióját: Várható, például, hogy a kisebb, veszteségesebb cégek jobban ki vannak téve a piac reakcióinak, mint a nagyobb, profitábilisabbak.

Az eredmények kimutatják, hogy a tőzsdei reakciók eltérőek a pénzügyi mutatók függvényében. Pozitív belső események nagyobb reakciót váltanak ki a kisebb, kevésbé profitábilis vállalatok esetében. A környezet jobbítására irányuló intézkedések szintén kifizetődőbbek a piac által kockázatosabbnak ítélt a vállalatoknál. Legkevésbé a magas adósságállományú vállalatok profitálnak. A negatív hírek a nagyobb, kevésbé profitábilis és rizikósabbnak itélt vállalatokat érintik a legjobban.

H3: A média figyelme befolyásolja a piaci reakciókat: Várható, hogy a közleményekben kevésbé gyakran szereplö vállalatokat erősebb piaci reakciók érik, mint a folyamatosan a figyelem előterében állókat.

A fenti megállapítás mind a pozitív belső mind a negatív külső hírek esetében igazolás nyert. Viszont a büntetések és perek esetében a nagyobb nyilvánosság magasabb veszteségekhez vezetett. Ehhez valószínűleg hozzájárul a $\mathrm{H}_{2}$-ben már megállapított méret tényező.

$\mathbf{H}_{4}$ : A cég környezeti reputációja befolyásolja a piaci reakciókat: Várható, hogy a jó környezeti hírnév megvédi a vállalatokat a negatív események által kiváltott kedvezőtlen tőzsdei reakciók teljes hatásától. 
Habár a $\mathrm{H}_{4}$-es hipotézis általánosságban véve igaz, tehát a vállalat környezeti imázsa befolyásolja a piaci reakciókat, de a hatás iránya nem egyezik meg az eddigi kutatásokra alapozott előzetes elvárásokkal. Vagyis a kedvező környezeti megítélés nem csökkenti a negatív hírekre adott reakciókat, hanem növeli azt, míg a várt tompító hatást pont a pozitív hírekre adott reakcióknál figyelhetjük meg. Evvel szemben a rossz hírnévnek örvendő vállalatok jobban profitálnak pozitív kezdeményezéseikből, és kevésbé büntetik őket környezeti kihágásaikért.

H5: A piaci reakciók változnak az idö függvényében: Várható, hogy a környezetvédelmi témakör elötérbe kerülésével, illetve a nyilvánosság növekedésével a piac reakciói diferenciáltabbakká váltak.

Az eredmények igazolják azon elözetes várakozást, hogy a piaci reakciók változnak az idő függvényében. Ezen túl kimutatható, hogy a különböző eseménytípusok nem egymással párhuzamosan fejlödtek, hanem mindegyik eltérő életgörbét ír le. Itt is megfigyelhetjük a belső és külső forrásból származó hírek differenciálódását. Míg az elsőnél homogénebb addig a másiknál ciklikusabb abnormális hozamokkal. A pozitív belső kezdeményezésekre adott reakciók enyhe fölfelé ívelő tendenciát, a pozitív külső megítélésekre adottak viszont negatív tendenciát mutatnak. A negatív híreket (mind külső és belső) egyre kevésbe bünteti a piac. 


\section{4 Új és újszerü tudományos eredmények}

Kutatási munkámmal az alábbi új- és újszerü tudományos eredményeket értem el:

1. Az eseménytanulmány GARCH specifikációjú módszerét Magyarországon elsőként alkalmaztam a vállalatokkal kapcsolatos környezeti hírek piaci reakcióinak elemzésére.

2. Az élelmiszeripari ágazat pénzügyi és környezeti tevékenységének összefüggéseit vizsgálva egy a nemzetközi szakirodalomban is felismert hiányosságot igyekeztem pótolni, mely az iparág kiemelt fenntarthatósági szerepe miatt rendkívül időszerủ volt.

3. A környezeti események híreire adott tőzsdei reakciók vizsgálatával, igazoltam hogy a tőzsde szelektív az események értékelésében. Az események típusokra bontásával megállapítottam, hogy a tőzsde elsősorban a konkrét - várt vagy valós- pénzügyi eredményeket befolyásoló vállalati kezdeményezéseket preferálja.

4. A vállalati szintủ változók bevonásával bebizonyítottam, hogy a tőzsdei reakciók függnek a specifikus vállalati jellemzőktől. A nagyobb, jobb hírnevü cégeket erősebb negatív reakciók érik, míg a kisebb, és kevésbé környezettudatosnak ítélt vállalatok jobban profitálnak pozitív kezdeményezéseikböl.

5. A tőzsde környezeti hírekre adott reakcióinak hosszútávú elemzése felfedte az események különböző típusokra osztásának szükségességét. Kimutattam, hogy a piaci reakciók nem csak hogy változnak az idő függvényében de az esemény jellegétől függően különböző életgörbét írnak le. 


\section{KÖVETKEZTETÉSEK ÉS JAVASLATOK}

\subsection{A környezeti események típus szerinti elemzéséből származó következtetések és javaslatok}

Disszertációm első kérdéseként arra voltam kíváncsi, hogy vajon a különféle környezettel kapcsolatos hírek, ugyanolyan hatást váltanak-e ki a vállalatok tőzsdei áraira? Melyek azok az események, melyekre a piac reagál, és melyek azok, amelyekre nem? Mint azt a szakirodalom áttekintéséből is vártam, a piac reakciói differenciálódnak az események típusa szerint. Megerősítést nyert, hogy a pozitív hírek a tőzsdei árak emelkedéséhez, míg a negatívak veszteségekhez vezetnek. A disszertációmban alkalmazott felosztás alapján viszont az is kitünik, hogy a piac nem helyez akkora hangsúlyt harmadik személytől eredő elemzésekre, rangsorolásokra és értékelésekre, mint azt gondolnánk. Keresztmetszeti elemzésem második lépéséből (ld. 6.2) azonban kitünik, hogy ha direkt összefüggés nem is kimutatható, az ilyen típusú hír cikkelyek igenis befolyásolják a vállalatokról alkotott általános véleményt.

Az E1 és E2 típusú (belső) eseményekre adott magas szignifikanciájú reakciók legfőbb oka valószínüleg az, hogy ezen kezdeményezések többnyire tényleges, közvetlen pénzügyi következményekkel járnak és ezért a befektetők elsősorban ezeket az eseményeket tartják értékteremtőnek, vagy rombolónak.

Az események további bontása (pl. a proaktív és az utólagos javító intézkedések közötti differenciálás) értékes információtartalommal szolgálhat a vállalatok számára atekintetben, hogy mely környezetvédelmi kezdeményezésekre érdemes erőfeszítéseiket koncentrálni.

\subsection{A vállalati jellemzők szerinti elemzéséből származó következtetések és javaslatok}

Az események típusán túl, nyilván a vállalati jellemzők is befolyásolják a piaci reakciókat. Az eddigi kutatásokból kitünik, hogy a több iparágat felölelö, illetve a cég-specifikus tulajdonságokat figyelmen kívül hagyó tanulmányok eredményei ellentmondásosak és sokszor nem értelmezhetőek. Vizsgálataimat egyetlen iparágra leszúkítve egyes, az összes élelmiszeripari céget érintő, piaci hatásokat ki tudtam zárni, és így a cég-specifikus jellemzőkre tudtam koncentrálni. 
A pénzügyi változók vizsgálata után néhány érdekes következtetés lehet levonni. Habár többnyire ezeknek a cégeknek van a legkevesebb szabadon felhasználható tőkéjük, mégis ezek a kisebb és kevésbé nyereséges vállalatok profitálnak legjobban pozitív irányú kezdeményezéseikből. Ezen vállalatoknak ezért érdemes elgondolkozniuk, hogy erőforrásaikat már eleve környezettudatosabb technológiákba fektessék. Ugyanakkor a nagyobb vállalatok, pénzügyi helyzettől függetlenül, jobban teszik, ha minta-állampolgárokká vállnak, mert a sajtó és a befektetők is árgus szemekkel figyelik őket. Ezeket a vállalatokat előszeretettel támadják a környezetvédelmi aktivisták, és még a kormányok is szívesen szabnak ki nagyobb összegü bírságokat.

A két nem-pénzügyi változóból nyert eredmények talán a legkomplexebbek és legnehezebben értelmezhetőek. A jó környezeti imázzsal rendelkező és a médiában gyakran szereplö vállalatoknak kell legjobban odafigyelniük környezeti tevékenységükre. Nem csak, hogy sokkal nagyobb eröfeszítéseket kell tenniük, hogy pozitív kezdeményezéseik pénzügyileg is megtérüljenek, de ráadásul ballépéseiket is jóval keményebben bünteti a piac. Ugyanakkor, a "rossz-fiúk"-kal szemben sokkal elnézőbbek a befektetők. A külső szemlélők (környezetvédő és civil szervezetek, aktivisták stb.) által publikált hírek látszólag nem generálnak tőzsdei reakciókat, de ugyanakkor nagyon fontos szerepet töltenek be a vállalatokról alkotott általános kép illetve az uralkodó tőzsdei hangulat kialakításában.

Több mint valószínü, hogy a változók egymással is kölcsönös együtthatásban állnak, így további kutatás tárgyát képezheti pl. a méret és a média, vagy az imázs és a média együttes hatásának vizsgálata.

\subsection{A longitudinális elemzéséből származó következtetések és javaslatok}

A környezeti hírekre adott reakciók hosszanti elemzéséből kitünik, hogy a tőzsde, vagyis a befektetők, a társadalom környezetvédelemhez való általános viszonyával együtt változtatják hozzáállásukat. A mindenkori kormányzati döntések, és jogi változások szintén fontos szerepet játszanak mind a vállalatok, mind a befektetők környezettudatos magatartásának alakításában.

Az elemzésből kiderül, hogy a vállalatok fenntartható fejlődésre és a környezeti imázs kialakítására irányuló erőfeszítései csakis egy hosszútávú stratégia részeként lehetnek kifizetődőek. A negatív környezeti eseményekből származó hosszútávú reputációs veszteségek 
jóval nagyobbak, mint amennyit a vállalat rövidtávon megtakaríthat környezetromboló magatartásával.

A négy hírtípus eltérő pályát ír le. A pozitív belső kezdeményezésü hírek egyértelmüen felfelé mutató és erősödő tendenciát mutatnak. Ciklikusság nem kimutatható, volatilitásuk csökkent. Az ilyen típusú hírekre adott reakciók a legkiszámíthatóbbak. A pozitív külső forrásból származó hírek vesztettek kezdeti népszerüségükből, és habár szórásuk csökkent még így ki vannak téve az éppen aktuális piaci trendek, és átrendeződés szeszéjének. A negatív belső riportokra adott reakciók egyértelmüen lefelé ívelő görbét mutatnak, de egyre csökkenő tendenciával, tehát a piaci reakciók csökkenek. Az ok valószínüleg a számviteli törvények változásában keresendő, melyek nyomán a negatív környezeti eseményekből származó elörelátható kinnlevőségeket a vállalatoknak jelenteniük kell. Mindkét negatív hírtípusnál változatlanul megfigyelhetünk az átlagtól jelentősen eltérö kilengéseket (outliers), melyek az ilyen típusú hírek meglepetés értékét hangsúlyozzák. Itt egyértelmüen közrejátszik, hogy a negatív hírek általában erősebb reakciókat váltanak ki, de az is hogy ezeket a hírcikkelyeket jóval nehezebb menedzselni, mint a kedvező előjelüeket.

A fentiekből következik, hogy a cégeknek nem csak a saját egyedi helyzetükhöz, hanem a mindenkori társadalmi és politikai helyzethez is igazodva kell megtervezniük környezeti stratégiájukat. 


\section{7 ÖSSZEFOGLALÁS}

Az elmúlt évtizedekben a fenntartható fejlődés és környezetvédelem témaköre egyre fontosabb szerepet tölt be. Az élelmiszertermelő ágazat a természetes környezetünket érintő egyik legfontosabb tényezővé lépett elő.

A szakirodalom áttekintésekor a vállalati társadalmi felelősségvállalás és profitabilitás összefüggését taglaló kutatások főbb irányvonalait tekintettem át. A témakör elméleti és technikai szempontjait is elemeztem.

Kutatásom első részében megvizsgáltam, hogyan befolyásolják a különböző típusú környezeti hírek az élelmiszeripari vállalatok tőzsdei árait. Kimutattam, hogy a piac eltérően értékeli az eseményeket azok típusától és eredetétől függően. Míg a vállalatok belső tevékenységeiből fakadó pozitív illetve negatív hírek szignifikáns tőzsdei reakciókat váltottak ki, addig a külső értékelések, riportok és besorolások esetében értékelhető reakció nem volt kimutatható. A tőzsde tehát elsősorban a tényleges, vagy vélt (elvárt) dollárban mért hasznot hajtó intézkedéseket értékeli.

A második részben, a különböző vállalati szintű jellemzők piaci reakciókra kifejtett hatását elemeztem. Négy pénzügyi: méret, profitabilitás, kockázatosság és eladósodás, illetve két nem pénzügyi: média lefedettség, és környezeti imázs mutatót elemeztem. Itt egyértelműen kimutatható volt egy negatív elfogultság a nagyobb és jobb hírnévnek örvendő cégek irányába; e vállalatoknal sokkal körültekintőbbnek kell lenniük környezeti imázsuk menedzselésekor.

Legutoljára a piaci reakciók időbeli alakulására voltam kíváncsi. A környezetvédelmi témakör népszerüségének növekedésével, az etikus befektetési alapok elterjedésével illetve az információs forradalommal egyidejüleg a piaci reakciók változását is megfigyelhetjük. Megállapítottam, hogy a piaci reakciókban fellelhető változások nem egyszerre, hanem eseménytípustól függően, különböző életgörbét leírva fejlődtek. A pozitív vállalati kezdeményezések sokkal kiszámíthatóbbak és növekvő piaci tendenciát mutatnak, míg a negatív hírek ciklikusabbak és hevesebb reakciókat váltanak ki.

Kutatásomnak két fö célja volt. Először is, az élelmiszeripar környezeti teljesítményének pénzügyi hatásvizsgálatával, egy a szakirodalomban létező hiányosságot szerettem volna pótolni. Másodszor pedig, az etikus befektetés és a média a vállalatok környezeti viselkedésének befolyásolásában betöltött szerepének fontosságára igyekeztem felhívni a figyelmet. 


\section{SUMMARY}

Sustainable development and environmental protection has been steadily gaining importance in the last two decades. The food production industry has been identified as one of the major players affecting our natural environment.

In the review of the related literature I have looked at the main trends that have emerged in the field of research examining the relationship betweencorporate social responsibility and company profitability. I have explored both the theoretical and the technical aspects of the topic.

In the first part of my research I have examined how various types of environmental news items affect the stock prices of the food companies. I have shown that the market places different values on the events depending on the type and the originator of the announcements. While events originating from internal actions of the companies, be that positive or negative, have created significant abnormal returns, the reports and rankings issued by third party observers have not. The stock market, therefore, primarily prizes those events that have a real, or expected monetary value placed on them.

In the second part I have examined how the various firm level characteristics are influencing market reactions. I have looked at four financial variables: size, profitability, company riskiness and indebtedness; and two non-financial variables: media coverage and environmental reputation. There was a definite negative bias toward the bigger and companies, thus these firms have to pay better attention to the managment of their environmental image. In the last part of my research I wanted to see whether market reactions have changed over time. I have found that with the growing importance of the environmental topic, the advancement of the information age and the development of the ethical funds market reactions have also changed. I have also discovered that reactions to the various event types examined have not developed paralel to eachother but each have shown a distinct life cycle. Reactions to positive company initiatives were more stable and have shown an upward trend in their market evaluation, while reactions to negative news were cyclical and unpredictable.

My work primarily had two main goals. Firstly, I wanted to fill a void by taking a closer look at the environmental stewardship of the food industry and its financial connotations. Second, I wanted to call attention to the importance of socially responsible investing and the media in regulating company environmental performance. 


\section{IRODALOMJEGYZÉK}

1. A.T. KEARNEY Consulting. (2009): Green Winners: The Performance of SustainabilityFocused Companies in the Financial Crisis. A.T. Kearney Management Consulting. http://atkearney.com/index.php/Publications/green-winners.html [2009 április 17]

2. ACCOUNTABILITY (2006, 2007): Accountability Rating Hungary, http://www.accountabilityrating.com/past_results.asp [2011 április 8]

3. AERTS, W., CORMIER, D., MAGNAN, M. (2008). Corporate environmental disclosure, financial markets and the media: an international perspective. Ecological Economics, 64 (3) 643-659.

4. AMERIKAI KERESKEDELMI KAMARA. (2011). Felelős vállalatirányítási és üzleti etikai szótár.http://www.amcham.hu [2011 junius 7]

5. ANDERSON, S., CAVANAGH, J. (2000): Report on the Top 200 Corporations, Institute for Policy Studies, December 2000, Washington D.C.

6. ANDERSON-WEIR, C.H. (2010): How Does the Stock Market React to Corporate Environmental News? Undergraduate Economic Review, 6 (1) 1-29.

7. BAILlIE, R.T., BOLLERSLEV, T. (1989): The message in daily exchange rates: a conditional-variance tale. Journal of Business \& Economic Statistics, 7 (4) 297-305.

8. BAILliE, R.T., DeGENNARO, R.P. (1990): Stock returns and volatility. Journal of Financial and Quantitative Analysis, 25 (2) 203-214.

9. BALL, R., BROWN, P. (1968): An empirical evaluation of accounting income numbers. Journal of Accounting Research, 6, 159-178.

10. BANSAL, P., CLELLAND, I. (2000): The market risk of corporate environmental illegitimacy. Academy Of Management Proceedings \& Membership Directory, pp. B1-B6.

11. BARNETT, M. L. (2007): Stakeholder influence capacity and the variability of financial returns to corporate social responsibility. The Academy of Management Review 32, 794-816.

12. BARNEY, J. (1986): Strategic factor markets: expectations, luck, and business strategy. Management Science, 32 (10) 1231-1241.

13. BARON, D. (2001): Private Politics, Corporate Social Responsibility, and Integrated Strategy. Journal of Economics \& Management Strategy, 10,7-45.

14. BARON, D., HARJOTO, M., JO, H. (2009): The economics and politics of corporate social performance. Research Paper Series, Stanford, the Graduate School of Business. https://gsbapps.stanford.edu/researchpapers/library/RP1993R.pdf [2011 augusztus 8]

15. BINDER, J.J. (1998): The event study methodology since 1969. Review of Quantitative Finance and Accounting, 11 (2) 111-137.

16. BIRD R., HALL, A. D., MOMENTE, F., REGGIANI, F. (2007): What Corporate Social Responsibility Activities are Valued by the Market? Journal of Business Ethics, 76, 189-206.

17. BOLLERSLEV, T. (1986): Generalized autoregressive conditional heteroskedasticity. Journal of Econometrics, 31 (3) 307-327.

18. BOLLERSLEV, T. (1987): A conditionally heteroskedastic time series model for speculative prices and rates of return. Review of Economics and Statistics, 69 (3) 542-547. 
19. BOLLERSLEV, T., ENGLE, R.F., WOOLDRIDGE, J.M. (1988): A capital asset pricing model with time-varying covariances. The Journal of Political Economy, 96 (1) 116-131.

20. BROWN, S.J., WARNER, J.B. (1980): Measuring security price performance. Journal of Financial Economics, 8, 205-258.

21. BROWN, S.J., WARNER, J.B. (1985): Using daily stock returns: The case of event studies. Journal of Financial Economics, 14 (1) 3-31.

22. CAMPBELL J.Y., LO, A.W., MACKINLAY, A.C. (1997): The Econometrics of Financial Markets. Princeton, NJ: Princeton University Press.

23. CAPELLE-BLANCARD, G., LAGUNA, M. (2010): How does the stock market respond to chemical disasters? Journal of Environmental Economics and Management, 59, 192-205.

24. CARHART, M.M. (1997): On persistence in mutual fund performance. Journal of Finance, 52 (1) $57-82$.

25. CERES (2006): Corporate Governance and Climate Change: Making the Connection. Boston, MA, http://www.ceres.org/resources/reports/corporate-governance-and-climate-change2006/view [2009 március 6]

26. CHAND, M. (2006): The Relationship between Corporate Social Performance and Corporate Financial Performance: Industry Type as a Boundary Condition. The Business Review 5 (1) $240-245$.

27. CHATTERJI, A., LEVINE, D., TOFFEL, M. (2009): How well do socially ratings actually measure corporate social responsibility? Journal of Economics and Management Strategy, 18 (1) 125-169.

28. CLARKSON, P., LI, Y., RICHARDSON, G., VASVARI, F. (2008): Revising the relation between environmental performance and environmental disclosure: en empirical analysis. Accounting, Organizations and Society, 33, 303-327.

29. CLIMENT, F., SORIANO, P. (2011): Green and Good? The Investment Performance of US Environmental Mutual Funds. Journal of Business Ethics, 103, 275-287.

30. COASE, R. (1960): The Problem of Social Cost. The Journal of Law and Economics, 3 (1) $1-44$.

31. COHEN, B., WINN, M. (2007): Market Imperfections, Opportunity and Sustainable Entrepreneurship. Journal of Business Venturing, 22 (1) 29-49.

32. COHEN, M.A., FENN, S.A., KONAR, S., NAIMON J. (1997): Environmental and Financial Performance: Are They Related? Working Paper.

33. CORHAY, A., RAD, A.T. (1996): Conditional heteroskedasticity adjusted market model and event study. The Quarterly Review of Economics and Finance, 36 (4) 529-538.

34. CORMIER, D., MAGNAN, M. (2007): The revisited contribution of environmental reporting to investors' valuation of a firm's earnings: an international perspective. Ecological Economics, 62 (3-4) 613-626.

35. DALY, H.E. (1973): Toward a Steady-state Economy. W.H. Freeman \& Co Ltd., San Francisco, CA. 332 p.

36. DASGUPTA, S., HONG, J.H., LAPlANTE, B., MAMINGI, N. (2006): Disclosure of 
environmental violations and stock market in the Republic of Korea. Ecological Economics, 58 (4) 759-777.

37. DASGUPTA, S., LAPLANTE, B., MAMINGI, N. (1998): Capital market responses to environmental performance in developing countries, World Bank, Development Research Group, Washington, D.C.

38. DASGUPTA, S., LAPLANTE, B. (2001): Pollution and capital markets in developing countries. Journal of Environmental Economics and Management 42, 310-335.

39. DEEGAN, C., GORDON, B. (1996): A Study of the Environmental Disclosure Practices of Australian Corporations. Accounting \& Business Research, 26 (3) 187-199.

40. DERWALL, J., GUENSTER, N., BAUER, R., KOEDIJK, K. (2004): The Eco-Efficiency Premium Puzzle. Financial Analysts Journal, 61 (2) 51-63.

41. DERWALL, J., VERWIJMEREN, P. (2007): Corporate Social Responsibility and the implied cost of equity capital. Working Paper

42. DOW JONES Sustainability Indexes, http://www.sustainability-index.com/ [2011 október 10]

43. DOWELL, G.A., HART, S., YEUNG, B. (2000): Do Corporate Global Environmental Standards Create or Destroy Market Value? Management Science, 46 (8) 1059-1074.

44. DUNN \& BRADSTREET, http://www.dnb.com/ [2011 január 15- március 15]

45. DYCKMAN, T., PHILBRICK, D., STEPHAN, J. (1984): A comparison of event study methodologies using daily stock returns: A simulation approach. Journal of Accounting Research, 22 (Supplement), 1-30.

46. EAP. (2010): Corporate agribusiness and America's waterways. Environment America Research and Policy Center, Boston, MA, p. 4-42.

http://www.environmentamerica.org/sites/environment/files/reports/EnvAm_Ag_v6_print.pdf [2011 július 2]

47. ENGLE, R.F. (1982): Autoregressive conditional heteroskedasticity with estimates of the variance of U.K. inflation. Econometrica, 50 (4) 987-1008.

48. ETC/SCP (2009): Environmental Pressures from European Consumption and Production. European Topic Centre for Sustainable Consumption and Production Working Paper 1/2009, Copenhagen, p. 10-67.

49. ETC/SCP (2011): Progress in Sustainable Consumption and Production in Europe. European Topic Centre for Sustainable Consumption and Production Working Paper 1/2011, Copenhagen, p. 5-89.

50. EUROPEAN COMMISSION (2001): Green Paper: European framework conditions for corporate social responsibility., July 2001.

51. EUROPEAN COMMISSION (2005): Attitudes of European citizens towards environment, Eurobarometer 217, April 2005.

52. EUROPEAN COMMISSION (2006): Green Paper: Promoting healthy diets and physical activity: a European dimension for the prevention of overweight, obesity and chronic diseases, December 2006.

53. EUROPEAN COMMISSION (2008): Attitudes of European citizens towards environment, Eurobarometer 295, March 2008. 
54. EUROPEAN COMMISSION (2008): Attitudes of European citizens towards environment, Eurobarometer 365, May 2011.

55. EUROPEAN COMMISSION (2011): A bizottság közleménye az európai parlamentnek, a tanácsnak, a gazdasági és szociális bizottságnak és a régiók bizottságának: A vállalati társadalmi felelősségvállalásra vonatkozó megújult uniós stratégia (2011-2014), COM/2011/0681 végleges, Október 2011.

56. EUROSIF. (2010): European SRI study. European Sustainable Investment Forum, Paris, p. 4-60.

57. FAMA, E. F. (1963): Mandelbrot and the stable Paretian hypothesis. Journal of Business, 36 (4) 420-429.

58. FAMA, E., FISHER, L., JENSEN, M.C., ROLL, R. (1969): The adjustment of stock prices to new information. International Economic Review, 10 (1) 1-21.

59. FAMA, E.F. (1991): Efficient capital markets II. Journal of Finance, 46, 1575-1617.

60. FAMA, E.F., FRENCH, K.R. (1992): The cross-section of expected stock returns. Journal of Finance, 47, 427-465.

61. FAMA, E.F., FRENCH, K.R. (1993): Common risk factors in the returns on stocks and bonds, Journal of Financial Economics, 33, 3-56.

62. FREEMAN, R. (1984): Strategic management: A stakeholder approach. Englewood Cliffs, N.J.: Prentice-Hall, p. 8-22.

63. FRENCH, K.R., SCHWERT, G.W., STAMBAUGH, R.F. (1987): Expected stock returns and volatility. Journal of Financial Economics, 19 (1) 3-29.

64. FRIEDMAN, M. (1970): The Social Responsibility of Business is to Increase Profits. New York Times Magazine. Vol. September 13, 32-33, 122-126.

65. GARCIA-CASTRO, R., CANELA, M. A., ARIÑO, M. A. (2008): Over the Long Run? Short-Run Impact and Long-Run Consequences of Stakeholder Management. Business and Society, doi:10.1177/0007650308315493.

66. GARCIA-CASTRO, R., CANELA, M. A., ARIÑO, M. A. (2010): Does Social Performance Really Lead to Financial Performance? Accounting for Endogeneity. Journal of Business Ethics. 92, 107-126.

67. GEMS Global Environmental Management Survey (1999): Nemzetközi felmérés a környezettudatos vállalat-irányítás helyzetéről Magyarországon. (International Survey of Environmental Firm Management Practices in Hungary) Környezettudatos Vállalatirányítási Egyesület, Budapest, p. 4-24.

68. GIACCOTO, C., ALI, M.M. (1982): Optimal distribution free tests and further evidence of heteroskedasticity in the market model. Journal of Finance, 37 (5) 1247-1257.

69. GILlEY, K. M., WORRELl, D. L., DAVIDSON III. W. N., EL-JELlY, A. (2000): Corporate environmental initiatives and anticipated firm performance. Journal of Management, 26 (6) 1199-1216.

70. GKI Gazdaságkutató Zrt. (2010): Fenntartható fejlődés évkönyv (Sustainable Development Annual Report), Budapest, 4-232.

71. GRIFFIN, J. J., MAHON, J. F. (1997): The Corporate Social Performance and Corporate Financial Performance Debate: Twenty-Five Years of Incomparable Research. Business and 
Society, 36 (1), 5-31.

72. GUENSTER, N., DERWALL, J., BAUER, R., KOEDIJK, K. (2006): The Economic Value of Corporate Eco-Efficiency. Academy of Management Conference Paper, Working papers series, http://papers.ssrn.com/sol3/papers.cfm?abstract_id=675628 [2011 augusztus 3].

73. GUPTA, S., GOLDAR, B. (2005): Do stock markets penalize environment-unfriendly behaviour? Evidence from India. Ecological Economics, 52 (1) 81-95.

74. GUTHRIE, J., CUGANESAN, S., WARD, L. (2008): Industry specific social and

environmental reporting: The Australian Food and Beverage Industry. Accounting Forum, 32, 1-15. 75. HALME, M., HUSE, M. (1997): The Influence of Corporate Governance, Industry and Country Factors on Environmental Reporting. Scandinavian Journal of Management, 13 (2) 137-157.

76. HAMILTON, J.T. (1995): Pollution as news: media and stock market reactions to the toxics release data. Journal of Environmental Economics and Management, 28 (1) 98-113.

77. HARTMANN, M. (2011). Corporate social responsibility in the food sector, European Review of Agricultural Economics, 38 (3) 297-324.

78. HDI, Human Development Index (2011): United Nations Development Programme, http://www.undp.org [2012 augusztus 8].

79. HICKS, J.R. (1939): The Foundations of Welfare Economics. The Economic Journal, 49, 696-712.

80. HORVÁTHOVÁ, E. (2010): Does environmental performance affect financial performance? A meta-analysis. Ecological Economics, 70 (1) 52-59.

81. HSIEH, D.A. (1989): Modelling heteroskedasticity in daily foreign-exchange rates. Journal of Business \& Economic Statistics, 7 (3) 307-317.

82. HUETING, R. (1990): The Brundtland Report: A matter of Conflicting Goals. Ecological Economics, 2 (2) 109-117.

83. ICID. (2005): International Commission on Irrigation and Drainage, http://www.icid.org/19cong_keizrul_presentation.pdf [2011 október 31]

84. IFIC (2010): Food \& Health Survey: Consumer Attitudes Toward Food Safety, Nutrition \& Health. International Food Information Council Foundation, Washington, D.C., http://www.foodinsight.org/ [2011 augusztus 8]

85. INCPEN (2001): Towards greener households - products, packaging and energy. INCPEN, London, http://www.incpen.org/pages/pv.asp?p=ipen203 [2012 augusztus 8]

86. IPPC. (2007): Climate Change 2007: Mitigation.Contribution of Working Group III to the Fourth Assessment Report of the Intergovernmental Panel on Climate Change. (Meyer, L.A. et al. szerk.) Cambridge: Cambridge University Press, 841 p.

87. ISO (2010). Guidance on social responsibility (ISO 26000:2010). Berlin.

88. JAFFE, A.B., PETERSON, S.R., PORTNEY, P.R., STAVINS, R.N. (1995): Environmental Regulation and the Competitiveness of U.S. Manufacturing: What Does the Evidence Tell Us? Journal of Economic Literature, 33 (1) 132-165.

89. JEGADEESH, N., TITMAN, S. (1993): Returns to Buying Winners and Selling Losers: Implications for Stock Market Efficiency. Journal of Finance, 48, 65-91.

90. JONES, P., COMFORT, D., HILLIER, D. (2008): Corporate social responsibility and 
marketing communications within stores: a case study of UK food retailers. Journal of Food Products Marketing, 14, 109-119.

91. JUNKER, L. (2005): Equity Carveouts, Agency Cost and Firm Value. Deutscher Universitaets-Verlag, Wiesbaden, $445 \mathrm{p}$.

92. KALDOR, N. (1939): Welfare Propositions of Economics and Interpersonal Comparisons of Utility. Economic Journal, 49, 549-552.

93. KARPOFF, J. M., LOTT, J.R., WEHRLY, W. (2005): The reputational penalties for environmental violations: empirical evidence. Journal of Law \& Economics, 48 (2) 653-675.

94. KEMPF, A., OSTHOFF, P. (2007): The effect of socially responsible investing on portfolio performance. European Financial Management, 13 (5) 908-922.

95. KING, A., BAERWALD, S. (1998): Using the Court of Public Opinion to Encourage Better Business Decisions, in Sexton K. et al (szerk.) Better Environmental Decisions: Strategies for Governments, Businesses and Communities. Washington, D.C.: Island Press, p. 309-330.

96. KING, A., LENOX, M.J. (2001): Does It Really Pay to Be Green? An Empirical Study of Firm Environmental and Financial Performance. Journal of Industrial Ecology, 5 (1) 105-116.

97. KING, A., LENOX, M.J. (2002): Exploring the Locus of Profitable Pollution Reduction. Management Science, 48 (2) 289-299.

98. KLASSEN, R. D., MCLAUGHLIN, C. P. (1996): The impact of environmental management on firm performance. Management Science, 42 (8) 1199-1214.

99. KOEHLER, D.A. (2006): Capital Markets and Corporate Environmental Performance: Research in the United States. In S. Schaltegger, \& M.Wagner (Eds.), Managing the business case for sustainability (pp. 211-231). Sheffield: Greenleaf Publishing.

100.KONAR, S., COHEN, M.A. (1997): Information as regulation: the effect of community right to know laws on toxic emissions. Journal of Environmental Economics and Management, 32 (1) 109-124.

101.KONAR, S., COHEN, M.A. (2001): Does the market value environmental performance? Review of Economics and Statistics, 83 (2) 281-289.

102.KONG D. (2012) Does corporate social responsibility matter in the food industry? Evidence from a nature experiment in China. Food Policy, 37, 323-334.

103.KOTHARI, S.P., WARNER, J.B. (2007): Econometrics of Event Studies. Handbook of Corporate Finance: Empirical Corporate Finance Vol. I, B. E. Eckbo szerk., North-Holland: Elsevier.

104.LANOIE, P., LAPLANTE, B., ROY, M. (1998): Can capital markets create incentives for pollution control? Ecological Economics, 26 (1) 31-41.

105.LAPLANTE, B., LANOIE, P. (1994): The market response to environmental incidents in Canada: a theoretical and empirical analysis. Southern Economic Journal, 60 (3) 657-672.

106.LINTNER, J. (1965): The Valuation of Risk Assets and the Selection of Risky Investments in Stock Portfolios and Capital Budgets. Review of Economics and Statistics, 47 (1) 13-37

107.LO, A.W., MACKINLAY, A.G. (1988): Stock market prices do not follow random walks: evidence from a simple specification test. Review of Financial Studies, 1 (1) 41-66. 
108.LYON, T.P., SHIMSHACK, J.P. (2011): Environmental Disclosure: Evidence from Newsweek's Green Companies Rankings. Working Paper, Stephen M. Ross School of Business, University of Michigan, Ann Arbor, MI.

109. MACKINLAY, A.C. (1997): Event studies in economics and finance. Journal of Economic Literature, 35 (1) 13-39

110.MALONI, M., BROWN, M. (2006): Corporate social responsibility in the supply chain: an application in the food industry. Journal of Business Ethics, 68, 35-52.

111.MARGOLIS, J. D., WALSH, J. P. (2003): Misery Loves Company: Rethinking Social Initiatives by Business. AdministrativeScienceQuarterly, 48, 268-305.

112.MAROM I. Y. (2006): Toward a Unified Theory of the CSP-CFP Link. Journal of Business Ethics, 67, 191-200.

113.McKENZIE, A.M., THOMSEN, M.R., DIXON, B.L. (2004): The performance of event study approaches using daily commodity futures returns. The Journal of Futures Markets, 24 (6) 533-555.

114.MEDIÁN Közvélemény és Piackutató Intézet - Braun \& Partners Kft. (2005): Reprezentatív kutatás a fogyasztók és a felelősségvállalás kapcsolatáról (A representative survey on what people know and think of CSR), http://www.braunpartners.hu/index.php?langcode=hu [24 June 2011]

115.MEDIÁN Közvélemény és Piackutató Intézet - Braun \& Partners Kft. (2006): Reprezentatív kutatás a fogyasztók és a felelősségvállalás kapcsolatáról (A representative survey on what people know and think of CSR), http://www.braunpartners.hu/index.php?langcode=hu [24 June 2011]

116. MINTEL. (2009): Attitudes towards food: Weight and diet, Mintel International Group Ltd., Chicago, Ill., http://oxygen.mintel.com/display/393509/ [2011 április 8]

117. MOLNÁR, M.A. (2006): A budapesti értéktőzsde hatékonysága. Hitelintézeti Szemle, 5 (56) 28-35.

118.MORSE, D. (1984): An econometric analysis of the choice of daily versus monthly returns in tests of information content. Journal of Accounting Research, 22, 605-623.

119. MUOGHALU, M.I., ROBISON, H., GLASCOCK, J.L. (1990): Hazardous waste lawsuits, stockholder returns, and deterrence. Southern Economic Journal, 7 (2) 357-370.

120.NEWSWEEK (2010): Newsweek’s Green Rankings, http://www.thedailybeast.com/content/newsweek/2010/10/18/green-rankings-globalcompanies.html [2011 április 19]

121.NICOLAU, J., SELLERS, R. (2002): The stock market's reaction to quality certification: empirical evidence from Spain. European Journal of Operational Research, 142 (3) 632-641. 122.ODOR K. (2009): An analysis of food-economy companies' environmental behaviour in North-East Hungary. Studies in Agricultural Economies, 109, 117-132.

123.OECD (2004): National Report: Hungary, Environmental Policy Tools and Firm-level Management Practices, Budapest, 4-58. 
124.OGDEN, S., WATSON, R. (1999): Corporate Performance and Stakeholder Management: Balancing Shareholder and Customer Interests in the U.K. Privatized Water Industry. Academy of Management Journal, 42 (5) 526-538.

125.OLSSON, R. (2007): Portfolio performance and environmental risk. Sustainable Investment Research Platform Working Papers. http://swoba.hhs.se/sicgwp/abs/sicgwp2007_004.htm [2011 április 8]

126. ORLITZKY, M., SCHMIDT, F. L., RYNES, S. L. (2003): Corporate social and financial performance: a meta-analysis. Organization Studies, 24 (3) 403-441.

127.PALMER, K., OATES W.E., PORTNEY, P.R. (1995): Tightening Environmental Standards: The Benefit-Cost or the No-Cost Paradigm? Journal of Economic Perspectives, 9 (4) 119-132.

128.PAULRAJ, A., de JONG, P. (2011): The effect of ISO 14001 certification announcements on stock performance. International Journal of Operations and Production Management, 31 (7) 765-788.

129.PESONEN, I., HEIKKURINEN, P., JALKANEN, L., KATAJAJUURI, J.-M., FORSMANHUGG, S. (2011): Environmental responsibility in the food chain : what to measure? In: EMAN-EU 2011 conference : accounting for climate change : what and how to measure : proceedings / toim.Mária Csutora, Sándor Kerekes. p. 220-231.

130.PIGOU, A.C. (1920): The Economics of Welfare. London: Macmillan.

131.PORTER, M., VAN DER LINDE, C. (1995): Toward a New Conception of the Environment-Competitiveness Relationship. Journal of Economic Perspective, 9 (4) 97-118.

132.PORTER, M.E. (1990): The Competitive Advantage of Nations. New York: Free Press. 133.PORTER, M.E. (1991): America's Green Strategy. Scientific American, 264 (4) 168.

134.ROWLEY, T., BERMAN, S. (2000): A Brand New Brand of Corporate Social Performance. Business and Society, 39, 397-418.

135.SAVICKAS, R. (2003): Event-Induced Volatility and Tests for Abnormal Performance. The Journal of Financial Research, Vol. XXVI, No. 2, 165-178.

136.SCHIPPER, K., SMITH, A. (1986): A comparison of equity carve-outs and seasoned equity offerings: Share price effects and corporate restructuring. Journal of Financial Economics, 15, 153-186.

137.SCHUBERT, A., LANG, I. (2005): The Literature Aftermath of the Brundtland Report: A Scientometric Study Based on Citations in Science and Social Science Journals. Environment Development and Sustainability, 7 (1) 1-8.

138. SEMENOVA, N., HASSEL, L. (2008): Financial outcomes of environmental risk and opportunity for US companies. Sustainable Development, 16, 195-212.

139. SHARPE, W.F. (1963): A Simplified Model for Portfolio Analysis. Management Science, 9, 277-293.

140.SHARPE, W.F. (1964): Capital asset prices: A theory of market equilibrium under conditions of risk. Journal of Finance, 19 (3) 425-442. 
141.SIR CADBURY, A. (2000): Foreword in Iskander M.R, Chamlou N. Corporate Governance: A Framework for Implementation. World Bank, Washington D.C. 222 p. 142.SJÖBERG, G.E. (2005): A globális falu már itt van - Az Amerikai Public Relations Szövetség (PRSA) 2005. évi konferenciáján elhangzott előadása, http://www.mprsz.hu/ContentShow.aspx?ContentID=43 [2012 augusztus 8]

143.SCHRECK, P. (2011): Reviewing the Business Case for Corporate Social Responsibility: New Evidence and Analysis. Journal of Business Ethics. 103,167-188.

144.STATMAN, M., GLUSHKOV, D. (2009): The wages of social responsibility. Financial Analysts Journal, 65 (4) 33-46.

145.The NEW YORK TIMES, http://www.nytimes.com/ref/membercenter/nytarchive.html/ [2011 januar 15- március 15]

146.The WALL STREET JOURNAL, http://online.wsj.com/public/page/proHelpCenterWelcome.html [2011 január 15- március 15]

147.The WORLD COMISSION ON ENVIRONMENT AND DEVELPMENT. (1987): Our Common Future. Oxford: Oxford University Press.

148.THOMSEN, M., MCKENZIE, A. (2001): Market incentives for safe foods: an examination of shareholder losses from meat and poultry recalls. American Journal of Agricultural Economics, 82, 526-538.

149.TIETENBERG, T. (1998): Disclosure strategies for pollution control, Environmental and Resource Economics, 11, 587-602.

150.USSIF (2009): Mutual funds performance. Social Investment Forum Foundation http://ussif.org/resources/mfpc/ [2009 november 2]

151.van BEURDEN, P., GOESSLING, T. (2008): The Worth of Values - A Literature Review on the Relation Between Corporate Social and Financial Performance. Journal of Business Ethics, 82, 407-424.

152.WADDOCK, S.A., GRAVES, S.B. (1997): The Corporate Social Performance-Financial Performance Link. Strategic Management Journal, 18 (4) 303-319.

153.WAGNER, M. (2010): The role of corporate sustainability performance for economic performance: a firm-level analysis of moderation effects. Ecological Economics, 69 (7) 1553-1560. 154.WANG Z., SALIN, V., HOOKER, N. H., LEATHAM, D. (2002): Stock market reaction to food recalls: a GARCH application. Applied Economics Letters, 9, 979-987.

155.WERNERFELT, B. (1984): A resource-based view of the firm. Strategic Management Journal, 5 (2) 171-180.

156.ZSÓKA Á., KEREKES S., CSUTORA M., HARANGOZÓ G., NÉMETH P. (2005): Befolyásunk a vállalatok környezetvédelmi magatartására. Környezeti nézőpontok. BCE Környezetgazd. tanszék, Budapest. p. 124-139. 


\section{MELLÉKLETEK \\ Vállalati adatbázis}

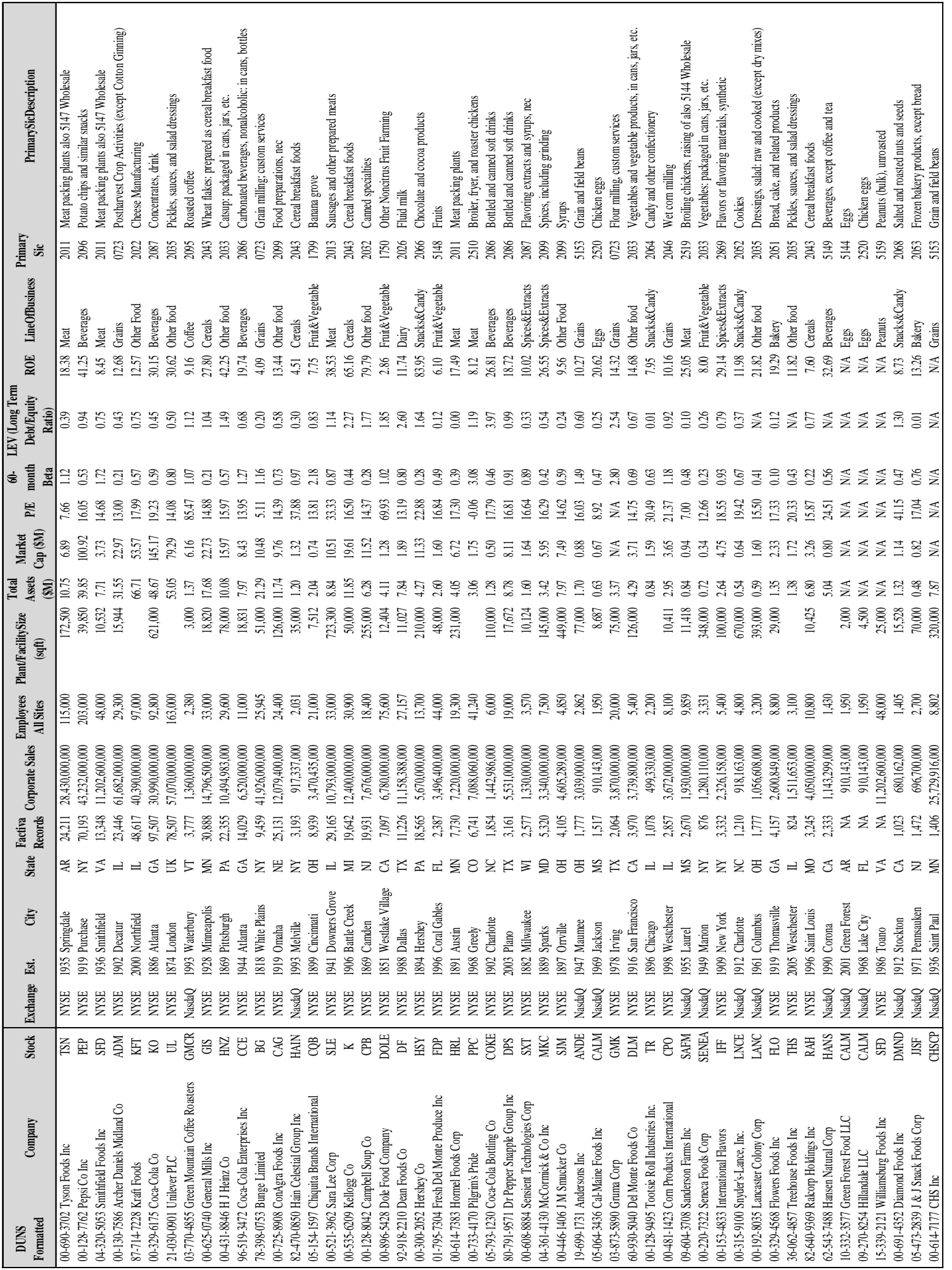




\section{KÖSZÖNETNYILVÁNÍTÁS}

Elsősorban szeretném megköszönni Szüleimnek erkölcsi támogatásukat, rendületlen türelmüket, bátorításukat, és szeretetüket, amely nélkül ez a dolgozat soha nem készült volna el.

Tisztelettel szeretném megköszönni Dr. Hajdu Istvánné témavezetőmnek, hogy kutatómunkámat és egyetemi elörehaladásomat figyelemmel kísérte, pártfogolta. Továbbá köszönet illeti a Corvinus Egyetem, Élelmiszeripari Gazdaságtan Tanszék illetve a Matematika és Informatika Tanszék minden munkatársait, akik a dolgozat elkészítéséhez támogatást nyújtottak.

Köszönettel tartozom Dr. Farkasné Dr. Fekete Mária, Dr. Kapronczai István és Dr. Podruzsik Szilárd opponenseimenk, hogy szakmai segítségükkel és támogatásukkal sikerült dolgozatomat véglegesíteni, továbbá társszerzőimnek, Dr. Hufnagel Leventének és Dr. Berna Karalinak, akikkel a kutatómunkám során együtt dolgoztam.

Külön köszönet illeti a University of Georgia, Agricultural and Applied Economics tanszékvezetőjét, Prof. Octavio Ramirezt, szíves meghívásáért és Prof. Wojciech Florkowskit útmutatásáért és támogatásáért illetve a tanszék minden munkatársát szívélyes vendéglátásukért. 


\section{A TÉMAKÖRBEN MEGJELENT PUBLIKÁCIÓK}

\section{Folyóiratcikkek}

Deák Zsuzsanna (2008). Élelmiszer vagy bioüzemanyag? - Lehetőségek és kockázatok, Élelmezési Ipar, LXII. évf. (2008) 7. szám, pp.193-197, ISSN 0013-5909

Deák Zsuzsanna - Hajdu Istvánné (2010). Fenntartható fejlődés és a fogyasztói társadalom, Agrár és Vidékfejlesztési Szemle, 2010 Vol. 5, pp. 516-521, ISSN 1788-5345

Deák Zsuzsanna - Hajdu Istvánné (2011). Az élelmiszeripari vállalatok környezeti teljesítményének megítélése a nemzetközi médiában, Élelmiszer Tudomány Technológia, LXV. évf. (2011) 3. szám, pp. 1-6, ISSN 2061-3954

Deák Zsuzsanna - Hajdu Istvánné (2011). Az élelmiszer-ipari vállalkozások környezeti teljesítménye és a pénzügyi eredmények, Gazdálkodás, 55. Évf. (2011) 7. Szám, pp. 662-667, ISSN 0046-5518

Zsuzsanna Deák - Istvánné Hajdu (2012). Environmental Reputation of Food Production Industry and its Financial Connotations, International Journal of Sales, Retailing and Marketing, Vol.1. No. 4, pp. 17-26, ISSN 2045-810X

Zsuzsanna Deák - Istvánné Hajdu (2012). The Role of Socially Responsible Investing and Media in the Environmental Stewardship of Food Industry Companies, Acta Alimentaria, Vol. 41. (Suppl.), pp. 25-39, ISSN 0139-3006 IF 0.444

Deák Zs., Hufnagel L., Hajdu I. (2013). The Impact of Perceived Corporate Environmental Performance on the Behavior of Capital Market Decision Makers: Analysis of Food Industry Companies, Applied Ecology and Environmental Research, ISSN 1785-0037 IF 0.547 (in press)

\section{Konferencia kiadványok}

\section{Magyar nyelvü (full paper)}


Deák Zsuzsanna (2009). A felelős vállalati magatartás és a tőkepiaci érték - amerikai esettanulmány és magyarországi vonatkozásai. Lokalizáció - Megoldás a fenntarthatóságra? LI. Georgikon Napok, Keszthely, 2009. október 1-2. pp. 170-179. ISBN 978-963-9639-35-5

Deák Zsuzsanna - Hajdu Istvánné (2011). Az élelmiszeripar zöld törekvései, Erdei Ferenc VI. Tudományos Konferencia, Kecskemét, 2011. augusztus 25-26. II. Kötet, pp. 47-52. ISBN 978615-5192-00-5

\section{Magyar nyelvü (abstract)}

Deák Zsuzsanna (2009). Corporate Responsibility and the Capital Markets - Comparative Case Study between the United States and Hungary. $51^{\text {st }}$ Georgikon Scientific Conference, Keszthely, 2009. október 1-2. Conference Abstracts, 1-2. pp. 38. ISBN 978-963-9639-34-8

Deák Zsuzsanna (2009). Környezettudatos vállalati magatartás és a tőkepiaci érték. Lippay János-Ormos Imre-Vas Károly Tudományos Ülésszak, 2009. október 28-30. pp. 224. ISBN 978963-503-397-3

\section{Nemzetközi konferencia (full paper)}

Deák Zsuzsanna (2011). Market Reactions to Environmental Information in The Food Production Industry, Journal of International Scientific Publication, Economy \& Business (2011) Vol.5., pp. 369-381, ISSN 1313-2555

Zsuzsanna Deák - Istvánné Hajdu (2012). Reputational Surveys and Company Perceptions: a Case Study in Hungary, World Congress of Administrative and Political Sciences, Antalya, Turkey, November 29- December 2, 2012. ISSN 1877-0428

\section{Nemzetközi konferencia (abstract)}

Zsuzsanna Deák - Istvánné Hajdu (2012). Environmental Reputation of Food Production Industry and its Financial Connotations, 9th Circle International Conference. Ibiza, Spain, 1113th April, 2012. Book of Abstracts, p. 62. ISBN 978-1-56592-479-6 